؟

Phuc Do Thi Kim

\title{
BARRIERS TO ENTREPRENEURSHIP IN HO CHI MINH CITY
}

Supervisor(s): Dr. Kirsi Hasanen Faculty of Management and Business

Master's Thesis

April 2020 


\section{ABSTRACT}

Phuc Do Thi Kim: Barriers to Entrepreneurship in Ho Chi Minh City

Master's Thesis

Tampere University

Faculty of Management and Business, Public Administration

April 2020

Entrepreneurship is one of the main strategies of countries, especially developing countries like Vietnam. Government of Ho Chi Minh City is using entrepreneurship as the effective implement to promote economy. Therefore, finding the barriers to prevent development of entrepreneurship is necessary. The aim of this study is to assess factors that affect the entrepreneurship development in Ho Chi Minh City. This thesis employs quantitative methods to conduct the research with sample size being 154 samples. The author evaluates Cronbach's Alpha reliability, EFA analysis, Pearson correlation analysis, determines and analyzes multivariate regression models; Multicollinearity assay and ANOVA. The results show that the regression model is suitable and does not have multicollinearity; three factors affect the entrepreneurship development in Ho Chi Minh City: (i) Individual factors; (ii) Environmental factors; (iii) Social - Cultural factors. Based on the found results, the author points out some management implications related to reject the barriers to entrepreneurship in Ho Chi Minh City and give some recommendations for making entrepreneurial policies.

Keywords: Entrepreneurs, Entrepreneurship, Behavior Characteristics, Environment, Society Culture

The originality of this thesis has been checked using the Turnitin OriginalityCheck service. 


\section{Table of Contents}

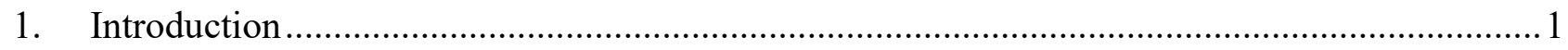

1.1 Background about entrepreneurship in Vietnam ……………............................................ 1

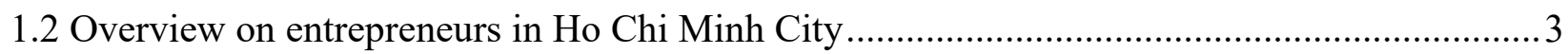

1.3 The limitations of entrepreneurial system in Vietnam.........................................................

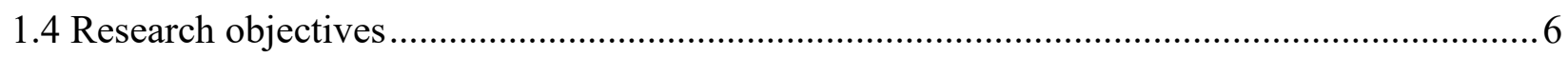

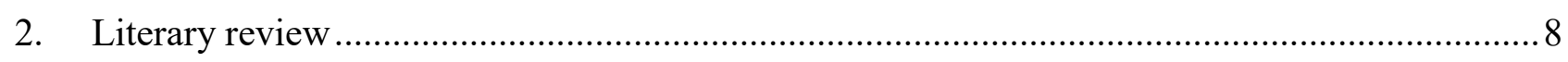

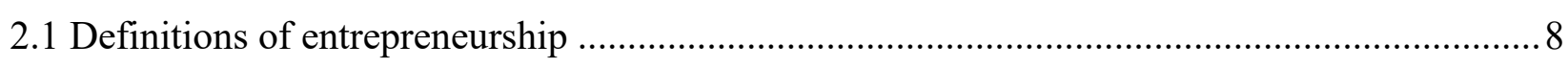

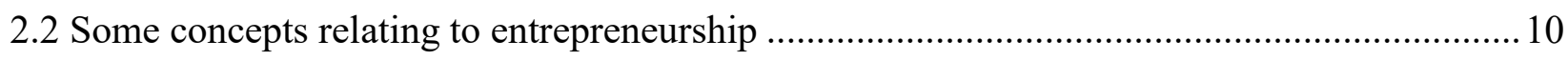

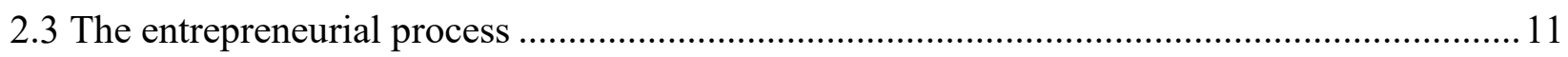

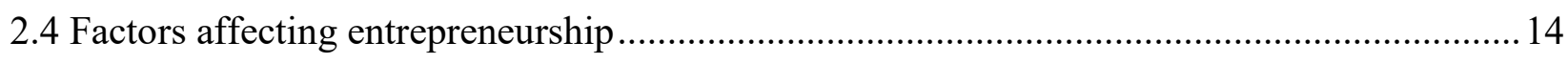

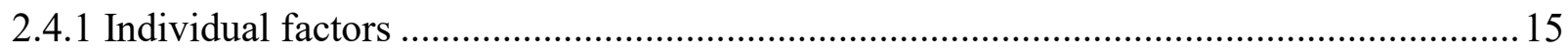

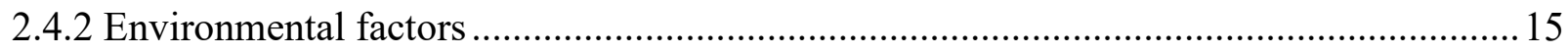

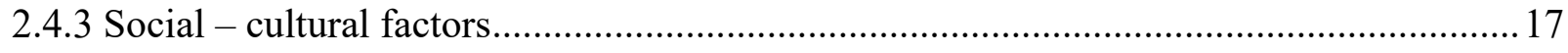

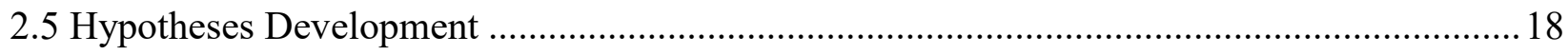

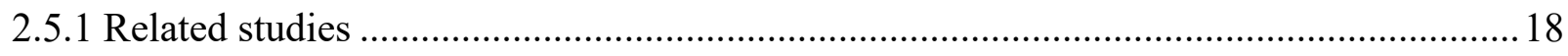

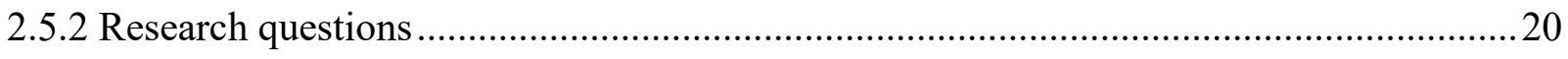

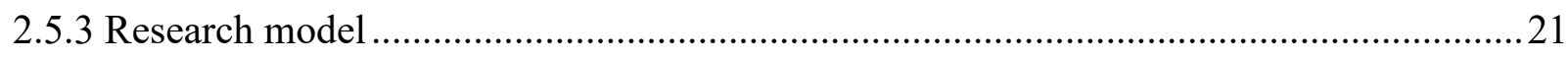

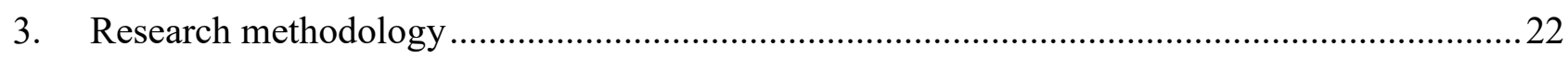

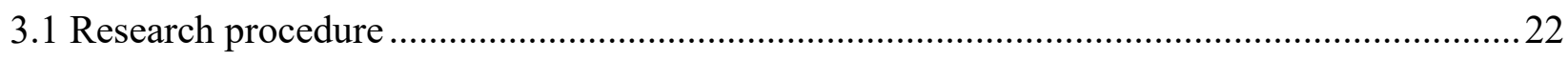

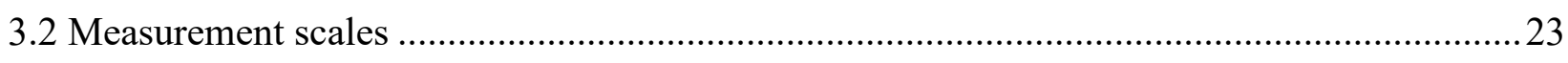

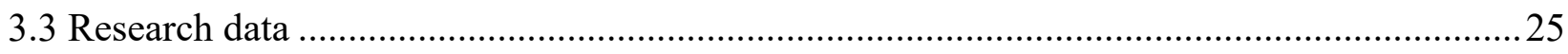

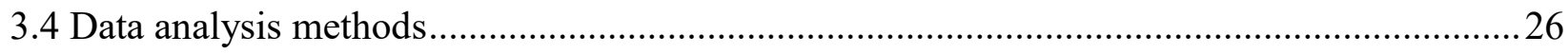

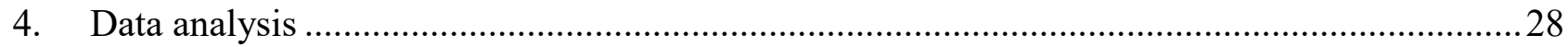

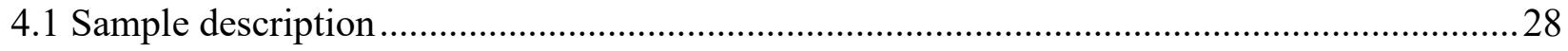




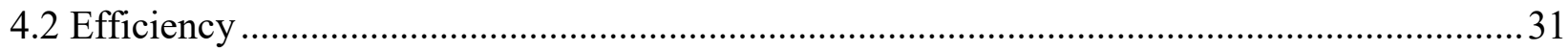

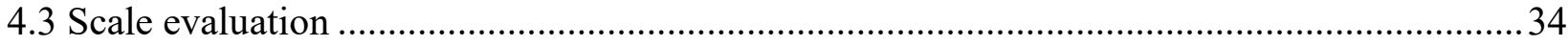

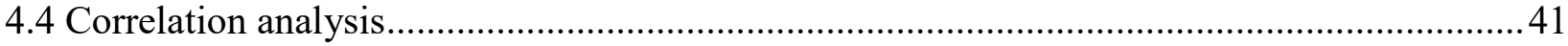

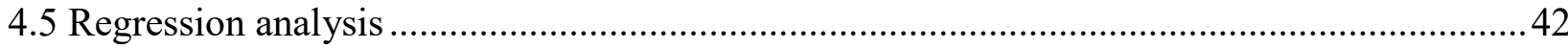

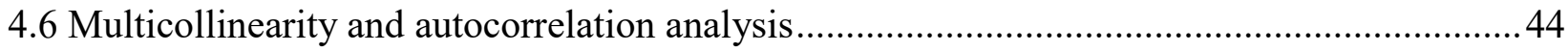

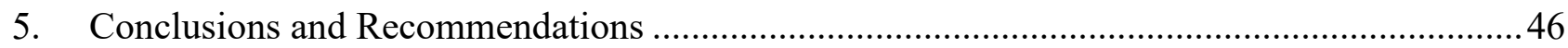

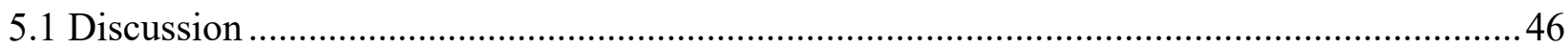

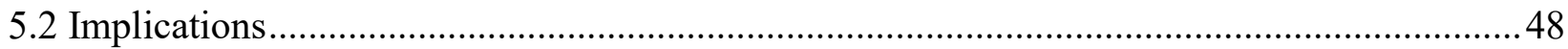

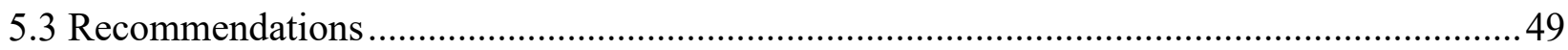

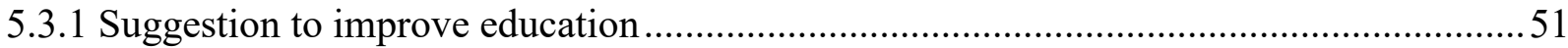

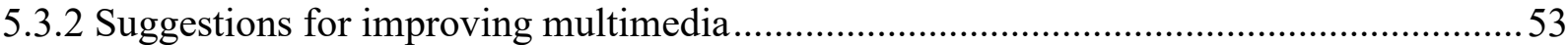

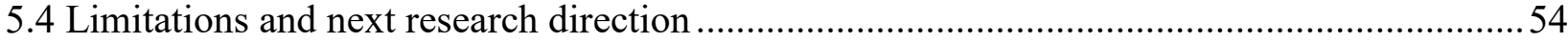

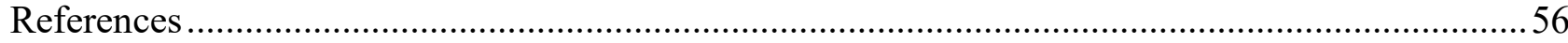




\section{List of Tables}

Table 1: Rankings and scores of indicators in the entrepreneurial ecosystem in Vietnam................5

Table 2: Summary of entrepreneurial studies using quantitative approach.................................. 18

Table 3: Summary of entrepreneurial studies using qualitative approach................................... 19

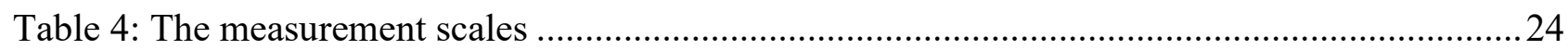

Table 5: Description of respondents about entrepreneurial characteristics in themselves. .............. 32

Table 6: Description of respondents about individual characteristics of entrepreneur.....................32

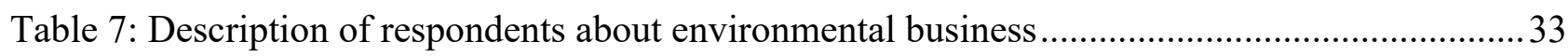

Table 8: Description of respondents about the view of social - culture for entrepreneurship ..........34

Table 9: : Reliability analysis and Exploratory Factor Analysis of Individual factor ......................35

Table 10: Reliability analysis and Exploratory Factor Analysis of Environmental factor ...............36

Table 11: Reliability analysis and Exploratory Factor Analysis of Social - Cultural factor............37

Table 12: Reliability analysis and Exploratory Factor Analysis of Entrepreneurship Development 38

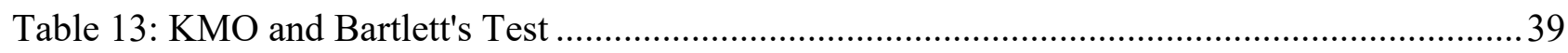

Table 14: Rotated Component Matrixa of dependent variable .................................................. 40

Table 15: Rotated Component Matrixa of independent variable ................................................. 40

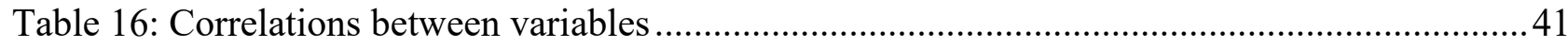

Table 17: Effect Coefficients between Independent Variables and BE ..........................................43

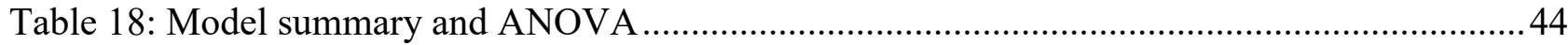




\section{List of Figures}

Figure 1: GRDP growth of Ho Chi Minh City in 6 months from 2015 to 2019 ............................. 3

Figure 2: Some supporting organizations for entrepreneurs...................................................... 4

Figure 3: Relationship of four core spirit elements of entrepreneurship .................................. 9

Figure 4: The model to create a new organization................................................................. 12

Figure 5: The entrepreneurial process by Hisrich \& Peters..................................................... 13

Figure 6: The entrepreneurial process by Van Der Zwan ........................................................ 13

Figure 7: The entrepreneurial process located within its environment and time........................... 14

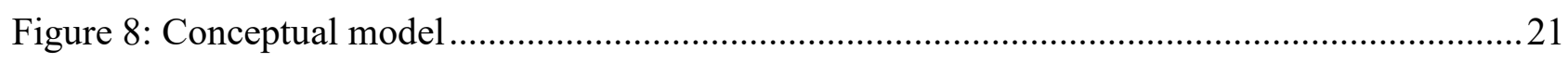

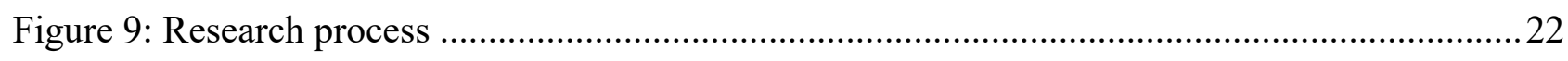

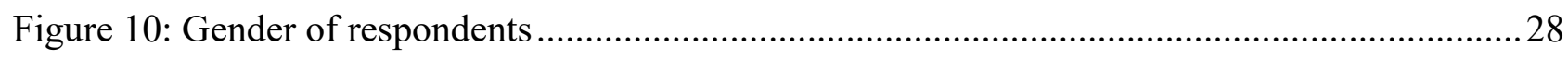

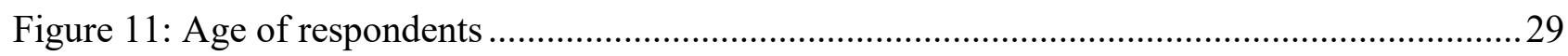

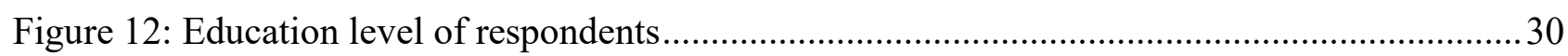

Figure 13: Reason to be entrepreneurs of respondents ....................................................... 31

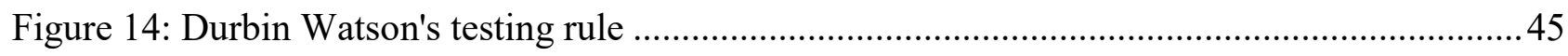

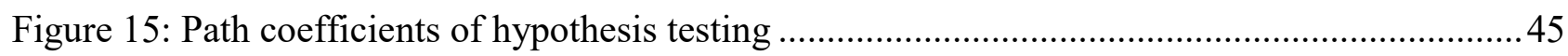




\section{Introduction}

In the global transformation of the economy from resources and capital to knowledge economy, as well as the fourth industrial revolution (the Industrial Revolution 4.0), entrepreneurs have recently become strong dynamic force of economic growth (Moica et al., 2013). According to Baumol (2004), entrepreneurs, especially startups, have been contributing in creating jobs for countries, even suggesting solutions to deal with challenges of society, like environment and Global climate. According to Drucker (2014), characteristics of entrepreneurs are creativity and acumen with innovations and finance. Hence, entrepreneurs have been called to create changes in economy and contribute to the regeneration of "aging" organizations. From that, the history of world economy has been distressed by the facts that the per capita income has increased 200 times in the United Kingdom and 700 times in the United States (Baumol, 2004), 95\% of paid wages in the United States and 34 million of businesses has been created by entrepreneurs' investment in 1980 (Timmons et al., 1994). In the recent years, the report of the Initialization Study Global GEM showed that there are approximate 400 million entrepreneurs in 54 countries been investigated, and many new jobs have been created every year by this business group ("Global Entrepreneurship Monitor Report 2015,” 2016). Asia-Pacific Economic Cooperation Forum affirmed that the member countries have a high number of start-ups, often achieve the outstanding economic growth rate and have the low unemployment rate (Sondari, 2014). Hence, entrepreneurship could be seen as an important strategy in the economic development of many countries such as the United States, Finland, Korea, Singapore, Israel and Japan (“Global Entrepreneurship Monitor Report 2015,” 2016).

In 2014, Vietnam experienced fast economic growth, however, the creative energy in science and technology was low, that made the economy to become weak and lacking sustainability (Do et al., 2015). Therefore, Vietnam has launched the promotion for entrepreneurship. Accordingly, the Vietnamese Government has rolled out a slew of initiatives - including a state-backing funding program to a growing entrepreneurial ecosystem. The investments, and mergers and acquisitions activities in Vietnamese entrepreneurs are expected to touch a total value of 2 trillion VND (approximately 89.3 million USD) by 2025 (Resolution No.35/NQ-CP).

\subsection{Background about entrepreneurship in Vietnam}

According to Yen (2017) the word "entrepreneur" appeared in Vietnam in 2000. Until 2003, through the Entrepreneur Idea Contest - being the first entrepreneurial contest, marking the birth of the National Entrepreneur Program. In the period from 2003 to 2012, people in general did not 
know and understand about meaning of entrepreneurship. This concept seemed to be a stranger to the young Vietnamese generation. Therefore, entrepreneurial activities just focused on providing basic knowledge about entrepreneurship, improving entrepreneurial spirit and developing creative ideas for young generation. In this period, many universities at provinces and cities throughout the country started to exchange the experiences of starting a business, launched a start-up competition and implemented communication about entrepreneurship. The result is the change in awareness of society, especially among the students.

In the new stage from 2013 to 2016, entrepreneurship has become an important strategy of the country. The National Entrepreneur Program has moved to the next stage: promoting the deployment of overall activities, towards formation of an entrepreneurial ecosystem. Missions of this stage were to maintain the main activities from the previous period and start the new activities, such as: support on searching and finding access to investment capital sources; development of Startup Clubs, Entrepreneurship Days, Idea Exchange, Innovative Business Idea Fair, Construction and Development of Portal and so on. One of the highlights of this stage is Techfest - the National Innovation Day held since 2015 by Ministry of Science and Technology, which has become the largest annual event for Vietnam's entrepreneurial community. The success of this event has contributed to government on building policy mechanisms and promoting entrepreneurship: building an entrepreneurial ecosystem of Vietnam, emphasizing the innovation and technologies, developing start - up incubator companies, and for the establishment of school - business government linkages (Entrepreneurs Portal, 2018).

From 2016, Resolution No.35/NQ-CP on supporting and developing enterprises by 2025 is promulgated marking positive, proactive and methodical development for the entrepreneurial community. The Vietnamese government approved a package of fresh initiatives aimed at paving the way for the boom in technology start-ups. Under the project, the government will provide legal and financial support for an estimated 2,600 entrepreneurs across the country over the next 10 years. Specifically, Viet Nam expects to support 1,000 entrepreneurs and projects, of which 50 should be able to garner investments from venture capital funds and be eligible for mergers \& acquisitions activities. These projects are seen to constitute a value of 1 trillion VND (approximately 44.65 million USD) by 2020.

Throughout the participation of both government and society, entrepreneurs' activities of Vietnam reach some achievements in recent years. According to the Statistics of one of the leading magazines about startups in Southeast Asia Echelon, Vietnam currently has about 3,000 innovative startups. Statistics of Topical organization Founder Institute (TFI) showed that in 2017 the number 
of creative investments nearly doubled in Vietnam received nearly double the number of injuries creative investment and there was a 50\% increase in total investment capital compared to 2016 (B. N. Quang, 2017).

\subsection{Overview on entrepreneurs in Ho Chi Minh City}

Ho Chi Minh City is the largest economic center of Vietnam. According to the overview of the City's socio-economic situation in the first 6 months of 2019, the rate of Gross Regional Domestic Product (GRDP) has grown by 7.86\% and the GRDP has reached 611,000 billion VND. The city's economy continues to be stable and develop. Regarding foreign investment, in the past 6 months, the city has attracted 3.2 billion USD, up $20 \%$ over the same period last year (while the country decreased) (Le, 2019). In term of business registration, total number of newly registered enterprises is over 20 thousands business, with total registered capital over 300.000 billion VND. (“Infographic: Economic picture of Ho Chi Minh City in the first 6 months of 2019," 2019)

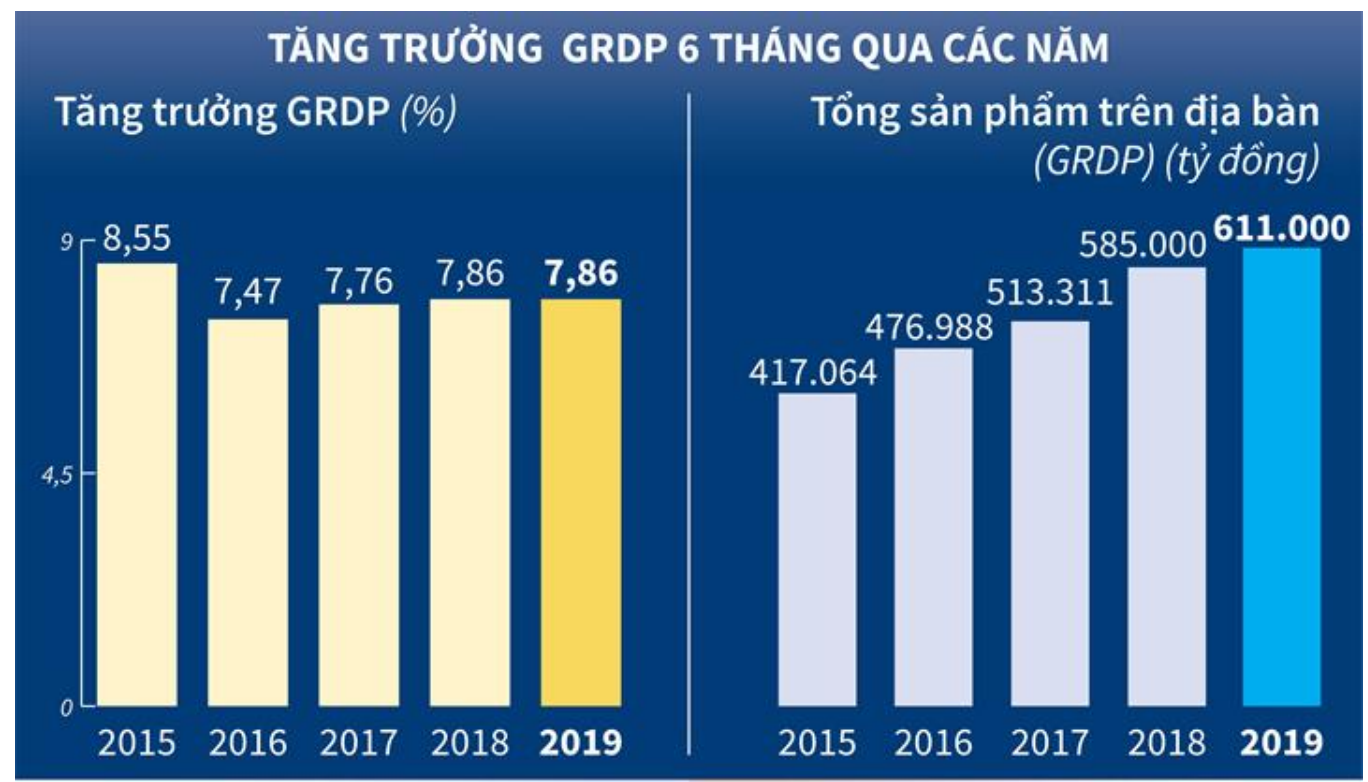

Figure 1: GRDP growth of Ho Chi Minh City in 6 months from 2015 to 2019

Source: ("Infographic: Economic picture of Ho Chi Minh City in the first 6 months of 2019," 2019) According to the report "Vietnam's Innovation Ecosystem 2019 Report" (Austrade, 2019), Vietnam ranked third in Southeast Asia in the number of startups with more than 3,000 startups. Since the beginning of 2019, many Vietnamese startups have successfully raised capital with total capital over 670 million dollars for about 50 deals. Ho Chi Minh City accounted for nearly half with 23 deals, equivalent to more than 300 million USD for capital. In addition, total supported projects are 1777 included activities: completing the business plan, connecting domestic and foreign market, supporting finance and developing entrepreneurial ideas. (Q. Anh, 2019) 
The achievements of Ho Chi Minh City are the result of many programs to support entrepreneurs of government and society. Firstly, from 2016, Government of city has improved and developed policies, giving special priorities to support the entrepreneurial community have a favorable environment for sustainable development like: administrative reforming, promoting trading, supplying information and advising judicial proceedings. ("Mechanisms and policies on entrepreneurship ecosystem," 2019). Secondly, some business startup support centers have been established. According to the report of Science and Technology Department of Ho Chi Minh City, there are currently 24 supporting organizations in the city (both public and private) (Huyen, 2019). The function of these organizations are consulting, connecting units in the ecosystem; assisting entrepreneurs in applying scientific and technological advances, managing intellectual property, seeking investment sources and providing co-working space. This is a new step of Ho Chi Minh City to build a strong and effective entrepreneurial ecosystem. With the encouragement of government, incubators, angel investors, venture capitalists, as well as domestic and foreign investment funds are taken part in to develop entrepreneurs and the entrepreneurial ecosystem of city. The figure 2 is some representative organizations to support entrepreneurs.

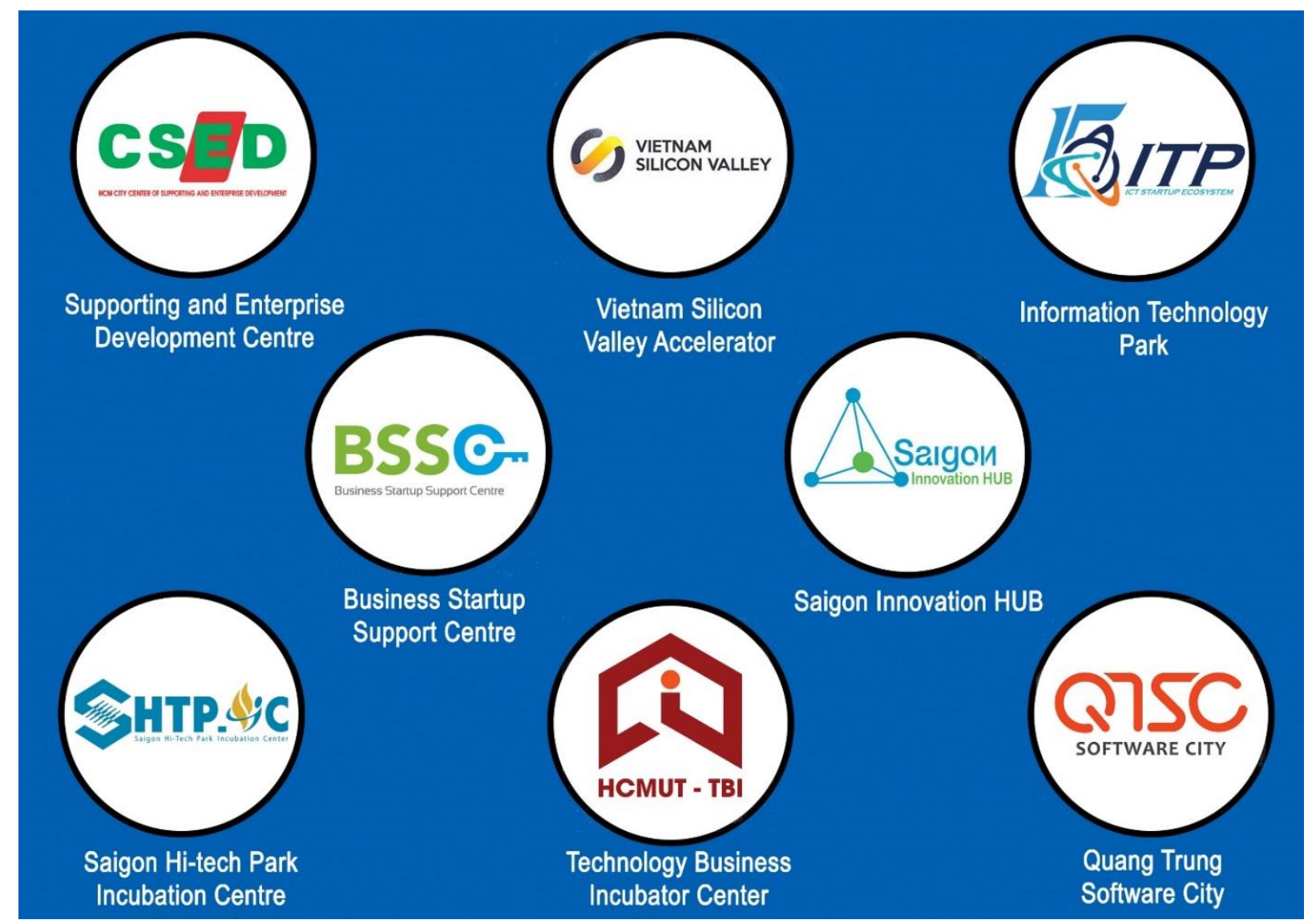

Figure 2: Some supporting organizations for entrepreneurs.

Source: author selected 


\subsection{The limitations of entrepreneurial system in Vietnam}

The quality of entrepreneurship is always an important problem of economy, because it is energy for the development, especially in rural Vietnam (Brünjes \& Diez, 2012). In recent years, there have been many cultural barriers affecting business performance in Vietnam (Hoang \& Dung, 2009; Vuong et al., 2018). It has led to decreasing interest rate (Vuong, 2016; Vuong \& Napier, 2014) and increasing risk in capital accumulation process (Vuong \& Napier, 2014). In addition, the study of Vuong \& Napier (2014) pointed out the reason for this phenomenon, that is the conflict of interest as well as the inability to optimize the human resources and resources of business for company's objectives. Other reason is the barriers in access to finance and regulations on trade and custom duties (Yen et al., 2019). Accordingly, entrepreneurial ecosystem in Vietnam have many hardships and challenges (Chieu, 2016).

According to "Global Entrepreneurship Monitor Report 2017-2018” (2018), comparing the entrepreneurial ecosystem in Vietnam with 54 other countries in the world, two indicators with the highest rankings are Dynamic of the domestic market (5/54) and Culture and social norms (6/54). Three indicators with the lowest-ranking in entrepreneurial ecosystem in 2017 were: Financial services for business (39/54), Post-secondary Business Education (40/54) and Government assistance program (43/54). Infrastructure index has the highest average score in Vietnam and ranks third among the 12 entrepreneurial ecosystem indicators, ranked as 10/54. Although the Government policies index is only rated at $2.4 / 5$ points, it is still ranked $13 / 54$. It is evident that many countries in the world have the same problem as Vietnam has in building a good and effective policy system to promote entrepreneurship and economic development. Three indicators with lowest-rankings in entrepreneurial ecosystem in 2017 were: Financial services for business (39/54), Post-secondary Business Education (40/54) and Government assistance program (43/54). Consequently, these factors can be considered as barriers to entrepreneurial development in Vietnam.

Table 1: Rankings and scores of indicators in the entrepreneurial ecosystem in Vietnam Source: “Global Entrepreneurship Monitor Report 2017-2018” (2018)

\begin{tabular}{|c|c|c|c|c|c|c|c|c|}
\hline \multirow{2}{*}{ Indicators } & \multicolumn{2}{|c|}{2017} & \multicolumn{2}{c|}{2015} & \multicolumn{2}{c|}{2014} & \multicolumn{2}{c|}{ Scale score: $1-5$} \\
\cline { 2 - 8 } & Scores & $\begin{array}{c}\text { Rank } \\
/ 54\end{array}$ & Scores & $\begin{array}{c}\text { Rank } \\
/ 62\end{array}$ & Scores & $\begin{array}{c}\text { Rank } \\
/ 73\end{array}$ & Scores & $\begin{array}{c}\text { Rank } \\
/ 69\end{array}$ \\
\hline $\begin{array}{l}\text { Dynamics of the } \\
\text { domestic market }\end{array}$ & 4.15 & 5 & 3.59 & 11 & 3.71 & 6 & 3.50 & 15 \\
\hline
\end{tabular}




\begin{tabular}{|l|c|c|c|c|c|c|c|c|}
\hline $\begin{array}{l}\text { Culture and social } \\
\text { norms }\end{array}$ & 3.62 & 6 & 3.23 & 14 & 3.13 & 17 & 3.10 & 20 \\
\hline Infrastructure & 4.19 & 10 & 4.07 & 17 & 3.75 & 39 & 3.58 & 43 \\
\hline $\begin{array}{l}\text { The openness of the } \\
\text { domestic market }\end{array}$ & 2.79 & 12 & 2.51 & 28 & 2.43 & 52 & 2.66 & 32 \\
\hline Government policies & 2.4 & 13 & 2.78 & 15 & 2.93 & 20 & 2.89 & 20 \\
\hline $\begin{array}{l}\text { Government } \\
\text { regulations }\end{array}$ & 3.02 & 25 & 2.62 & 25 & 2.46 & 32 & 2.77 & 13 \\
\hline $\begin{array}{l}\text { Technology transfer } \\
\text { Business education at } \\
\text { high school level }\end{array}$ & 1.83 & 34 & 1.57 & 47 & 1.83 & 51 & 1.97 & 46 \\
\hline $\begin{array}{l}\text { Business support } \\
\text { services }\end{array}$ & 2.82 & 36 & 2.93 & 42 & 2.93 & 41 & 2.89 & 45 \\
\hline $\begin{array}{l}\text { Financial services for } \\
\text { business }\end{array}$ & 2.27 & 39 & 2.12 & 50 & 2.37 & 44 & 2.40 & 42 \\
\hline $\begin{array}{l}\text { Post-secondary } \\
\text { Business Education }\end{array}$ & 2.61 & 40 & 2.53 & 47 & 2.64 & 58 & 2.64 & 50 \\
\hline $\begin{array}{l}\text { Government assistance } \\
\text { program }\end{array}$ & 2.09 & 43 & 2.14 & 50 & 2.35 & 54 & 2.50 & 38 \\
\hline
\end{tabular}

Ho Chi Minh City is recognized as a leader of entrepreneurship in Vietnam (Huyen, 2019).

However, some issues of the city have affected to this development. The research of Huynh (2019) presented five negative problems needed to be currently improved. First is the problem of national development strategy - the conflict between a market-led and state-led approach. Secondly, the fiscal share of city is lower the demand of the development. Thirdly, as most of the effort and resources are focused to solve directly urgent issues, the support for development strategies are limited, such as a public transport system or promotion of the formal economy. Fourthly, there is a lack of persistence and consistency in public entrepreneurship as well as lack of a master plan. In the reality, Ho Chi Minh City has operated without master plan since the early 1990s. The municipal government has focused on urban planning - a "facilitation vehicle" for the city's government, which has led to ineffective and unsynchronized development.

\subsection{Research objectives}

Since entrepreneurship has been studied widely both internationally and in Vietnam, it can lead to confuse for people who want to become an entrepreneur or simply study about entrepreneurship. Therefore, the first aim of this research is to produce an overview about the concept of "entrepreneur" and its contents. The thesis also provides a list of previous entrepreneurial research. 
The second purpose is to evaluate the effect of policies supporting entrepreneurship. Recently, Vietnam have many programs and policies to encourage entrepreneurship, particularly in Ho Chi Minh City. However, the question is do these support mechanisms respond to the demands of entrepreneurs? Besides, even though entrepreneurial research has increased and become more noticed, most of the studies focus on the factors affecting students' intention for becoming entrepreneurs, or to the of experience building entrepreneurial ecosystem, not on requirements of entrepreneurs. Therefore, the purpose of this research is to find the disadvantages entrepreneurs might meet when establishing a business.

Based on the survey for people in their pursuit of becoming entrepreneurs, thesis will analyze the affecting factors: individual characteristics, environment and society - culture to entrepreneurship. The thesis findings can provide evidences and recommendations to improve the recent support policies of government.

The thesis is organized into five part as follows:

Chapter 1 introduces the historical process and the context of entrepreneurship in Vietnam. The chapter also highlights some limitation on entrepreneurial ecosystem. The aim is to provide general information and a context for the research.

Chapter 2 will present the literature review that serves as the foundation theory of the study. The literature will define some concepts linked with entrepreneurship. This chapter also shows the conflicts between studies about the factors effecting entrepreneurship to develop hypothesizes. At the ends of chapter, a research framework will be mentioned as a theoretical guidance of the research.

Chapter 3 relates to research methodology. It will lay out the rationale for choosing a methods and design to collect data for the thesis.

Chapter 4 consist the analysis data and results of this study. The hypothesizes in previous chapter can be considered by the findings.

Chapter 5 is the end of thesis with discussing section about implications and limitation of the research as well as suggestions for future research. 


\section{Literary review}

To most effectively explore these issues surrounding entrepreneurship, a subset of literature has been selected based on its relevance to how entrepreneurship is defined and what factors are gathered as affecting to entrepreneurship.

\subsection{Definitions of entrepreneurship}

Carland, et al. (1988) recognized that frequent ambiguity in defining concepts similar the conceptualizing of blink men about elephant image, and each research can create deeper knowledge about the concept itself. There are two highlighted perspectives to define entrepreneurship: behavior approach and trait approach (Kobia \& Sikalieh, 2010).

In the behavior approach, Gartner (1988) and Gurel et al. (2010) both accepted that entrepreneurship forms an establishment independent company or start a new organizations. Entrepreneurship is considered the first stage of business' cycle that founders takes the advantage opportunities to develop new business ideas (Greve \& Salaff, 2003; Nabi \& Lin, 2011), it is not to include a corporate or intrapreneurial effort (Greve \& Salaff, 2003). It can be seen that self - control and self - employment is emphasized in the concept "entrepreneurship", distinguished from organizational employment (Kolvereid, 1996). Other authors believes that the above explanation is a narrow interpretation of entrepreneurship (Rauch \& Frese, 2007; Stuart \& Sorenson, 2005). The second opinion presents that entrepreneurship is a complex and dynamic process (Carland et al., 1988) consist of exploring, evaluating, exploiting and utilizing the opportunity to introduce new products or services, new ways to run businesses, new markets, or resources that have not appeared before (Ahmad \& Hoffman, 2007; Shane \& Venkataraman, 2000). Therefore, the opportunity recognition is the key part of entrepreneurship (Ardichvili et al., 2003; Kobia \& Sikalieh, 2010; Peneder, 2009); and it can be appear both in a new business or an existing organization (Davidsson et al., 2006; Shane \& Venkataraman, 2000). Following the developing of behavior approach in study of Stevenson (1983), this perspective can explain the general entrepreneurial situations and avoid the limited of individual traits. It can be said that entrepreneurs are recognized through their actions, not based on their personal psychological profile (Covin \& Slevin, 1991).

In term of trait approach, entrepreneurship is seen as the phenomenon of entrepreneurs who are evaluated making different decisions about opportunities than other people with the same information and skills (Shane, 2003). Thus, research on trait approach focuses on analyzing personality traits which lead to entrepreneurial activities (Hebert \& Link, 1989). In the studies of Kornai (1990) about free economy, Robbins et al. (1994) about management, Hammer \& Champy, 
(2007) about reengineering and Drucker (2014) about innovation, they have all agreed that the concept of "entrepreneurship" is associated with the concept of "entrepreneur". That means entrepreneurship is the core spirit elements of entrepreneur, expressed through motivation for achievement, taking risks, being creative, innovative and moving towards sustainable value. These core spirit elements have a dialectic and cyclical relationship which can be modeled and explained as in Figure 3. (Loc, 2011)

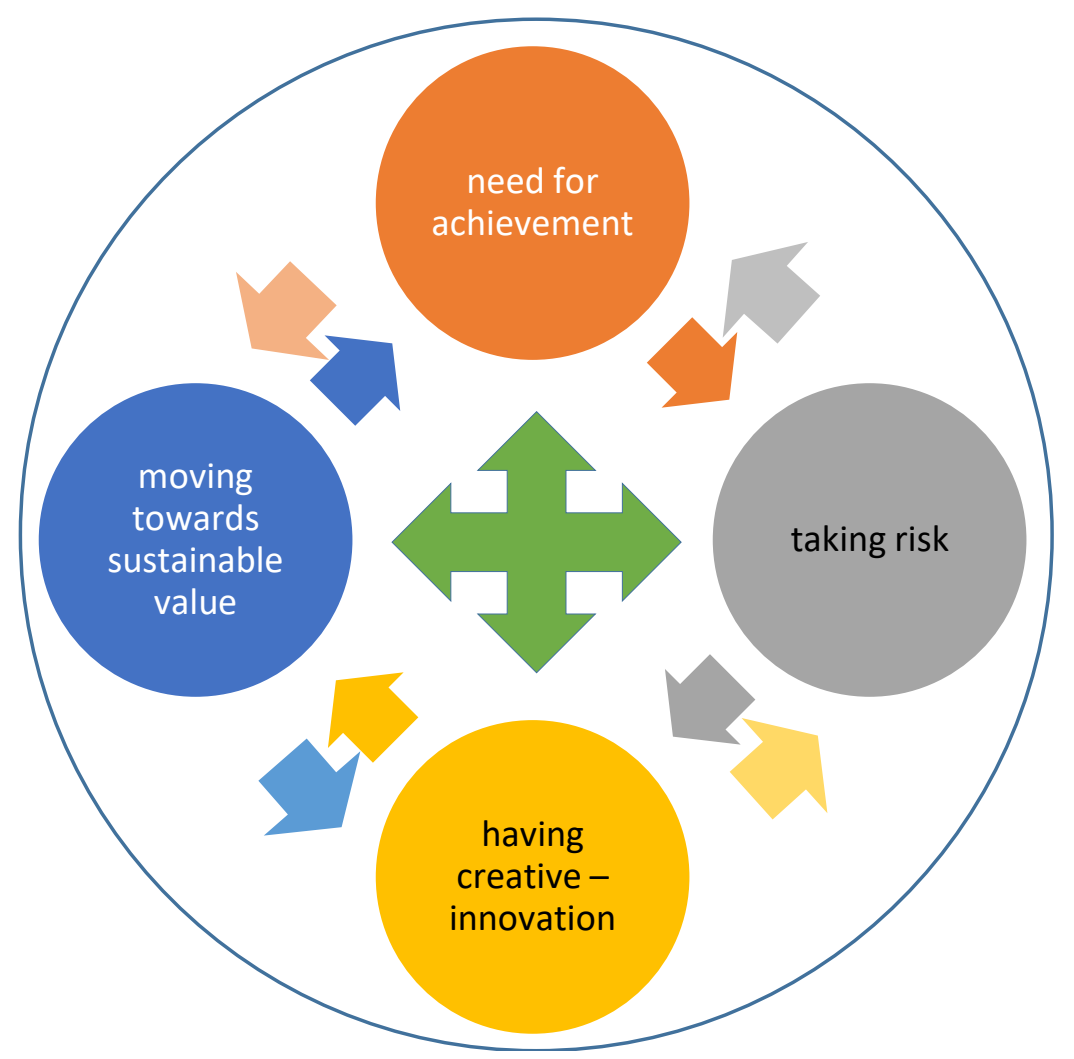

Figure 3: Relationship of four core spirit elements of entrepreneurship

Source: Loc (2011)

The studies done by Bull \& Willard (1993) and McClelland (1986) show high motivation as one of the entrepreneurial characteristics. Following that, the need to reach achievements, or the desire to solve the problem/know the outcomes of their decisions is the push energy for one person to eventually become an entrepreneur. This theory was applied in the research of Marques et al. (2013), and the result from the health service industrial entrepreneurs is an evidence for theory again.

Stewart \& Roth $(2001,2004)$ have disagreed with Miner \& Raju (2004) about risk propensity of entrepreneur. Following that, Stewart \& Roth (2001) agreed that entrepreneurs engage in a high risky behavior (new venture creation) and are generally believed to have a higher psychological 
propensity towards risk taking than non-entrepreneurs. In the meantime, Miner \& Raju (2004) provided the evidences that the relationship between risk taking and entrepreneur is uncertain, depend on different case or growing process, the high risk can be change. Hence, risk propensity is hard to become a key variable of entrepreneurship. Nevertheless, the perspectives of Knight and Cantillon are analyzed in the study of Iversen et al. (2008), which present a different reorganization of risk and uncertainty as well as on individual ability/willingness to accept entrepreneurial risk. According to Drucker (2014), innovation and creation are important characteristics of entrepreneurs. In addition, research of McClelland (1986) and Ko \& Butler (2007) show the role of creation and innovation in entrepreneurship, as it can be seen as the factor distinguishing an entrepreneurship with a traditional business from a simple form of management (Kukoc \& Regan, 2008). In the other words, entrepreneurship is the successful implementation of creative ideas and a particular form of innovation (Amabile, 1997).

Entrepreneurship can affect to the economy throughout different forms with many different outcomes, such as increasing production, creating financial wealth or employment, reduce poverty (Bruton et al., 2013), tackling inequalities, or indeed, solving environmental issues (Ahmad \& Hoffman, 2007). Hence, Iversen et al. (2008) emphasize the role of entrepreneurs to provide insurance in the economy and bring stability (equilibrium) to the economic system. It comes from sustainability and greening of entrepreneurship (Schaper, 2010).

Although not everyone has above characteristics to become entrepreneurs, these traits can explain entrepreneurial activities (Amit et al., 1993). Further, traits approach can solve the limits of the behavior approach. Entrepreneurship can appear in many field like the arts, science, and social development, not only exist in business contexts (McKenzie et al., 2007).

\subsection{Some concepts relating to entrepreneurship}

Based on motivation to enterprise, the research of Reynolds et al., (2000) classified into opportunity based ventures (OPP) and necessity based ventures (NEC). In OPP sense, entrepreneurship is threestep cycle: finding opportunities, exploring opportunities and exploiting opportunities, while NEC refers to a situation in which entrepreneurs had to start a business to survive, because of some push factors such as unemployment, dismissal, and poverty of family.

According to the characteristics, Antoncic \& Hisrich (2003) and Parker (2011) referred to business ventures as nascent intrapreneurship (NI) and nascent entrepreneurship (NE). The term NE is used on individuals establishing an independent enterprise, which is not controlled or sponsored by other operating businesses. Thus, the independent enterprise is owned by individual founders and 
investors. NI refers to creating a new business from exploiting the opportunities arising from the current operating company, based on new ideas or intention to improve ineffective resources (Märijärvi et al., 2016). There is evidence that entrepreneurial activities in this situation are supported and owned by the current companies, to renew, revitalize and enhance their overall business performance (Antoncic et al., 2001; Kuratko et al., 1990)

Research of Abbate \& Cesaroni (2014) and Bigliardi et al., (2013) define startups being related to entrepreneurship based on science and technology. In a similar vein, in Vietnam the term startup is used in reference to science and technology entrepreneurs or as innovative/ creative startups ("Global Entrepreneurship Monitor Report 2015," 2016). This definition has the similar with the explanation of Bailetti (2012) about technology entrepreneurship. Thus, the term makes a distinction from 'normal' entrepreneurs whose companies are established based on traditional industries or are not applying advanced science and technology into production and business. However, both technology-based entrepreneurs (TBE) and non-technology-based entrepreneurs (NBE) participates in venture creation processes (Jon \& Welsch, 2008). In addition, Van de Ven et al., (1984) have suggested that the designing process of startups includes three considerations: entrepreneurs, organization and ecology. That means applying science and technology is not necessary. Therefore, Blank (2010) defined "a startup is an organization formed to search for a repeatable and scalable business model.". Research \& development (R\&D) activities as well as innovative activities are the key to overcome the disadvantages of markets (Audretsch \& Acs, 1994).

\subsection{The entrepreneurial process}

Entrepreneurial process is a course of actions from initiate stage to stable developing stage, including all activities and actions associated with identifying and evaluating perceived opportunities, using limited resources to establish a successful business (Bygrave \& Hofer, 1992; Cronje et al., 2002; Mutisya, 2011). There are many theoretical models of entrepreneurial process which differ in the assumptions and variables encompassed. Nevertheless, all models still have enough core or essence of entrepreneurship on recognizing or creating opportunities; creating value for stakeholders; and the significant role of temporality, action (or commitment to action), and context (Cronje et al., 2002; Moroz \& Hindle, 2012). Different authors have different divisions from three to five distinct stages in the entrepreneurship process.

Based on multiple studies, entrepreneurship is a process which have three stages, namely propensity, intention and decision (Bhave, 1994; Krueger \& Brazeal, 1994; Learned, 1992). Learned (1992) recognizes that not all people can be entrepreneurs. Potential entrepreneur is someone who has the ability to realize and capitalize on opportunity to found a business, but may 
not have any salient intentions toward starting a business (Krueger \& Brazeal, 1994). It distinguishes with intending entrepreneur who have orientation to become an entrepreneur (Kouriloff, 2000). Many studies demonstrate the relationship between personal intention and entrepreneurial decision (Douglas \& Shepherd, 2002; Ozaralli \& Rivenburgh, 2016). That means a decision to start a business is a result of changing thinking process from none idea to action desire. This process can be explained by theory of planned behavior of Ajzen (1991) (Zhao et al., 2005). The result of entrepreneurial decision is creating a new venture. Figure 4 shows the simple process of an entrepreneur to create a new organization.

\section{A Model of Organization Formation}

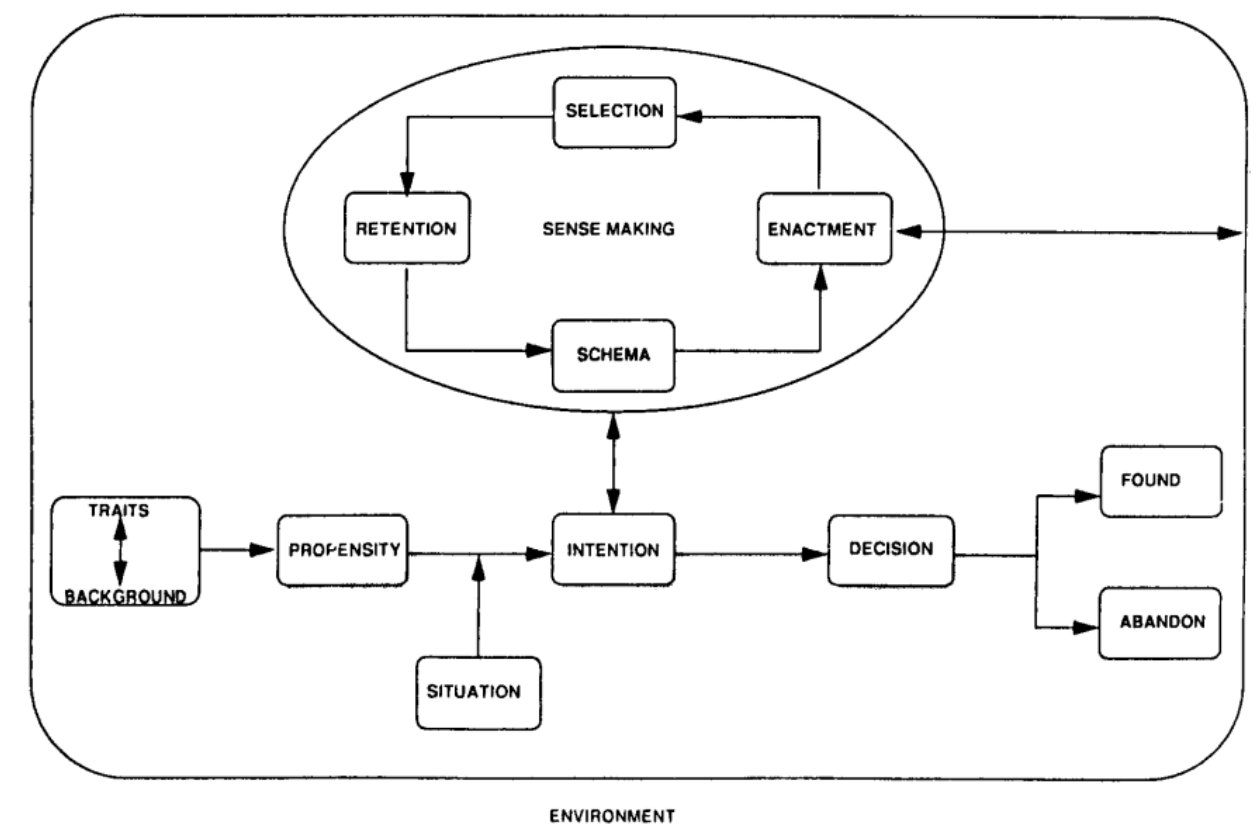

Figure 4: The model to create a new organization.

Source: Learned (1992) and Krueger \& Brazeal (1994)

Other entrepreneurial process described by Hisrich \& Peters, includes four stages: innovation, triggering event, implementation and growth (Cronje et al., 2002). Innovation is a beginning stage in which an idea is created, a market opportunity is determined, information is searched and ideas' feasibility is checked. Then, the activities considered as "triggering event" for the next step, are acted, like the decision to proceed, the business planning, identifying the different resources required, risk assessment, resource acquisition and assembling. After that, a new business is established, run and managed. The last stage of entrepreneurial process is "growth" which includes developing the new venture, improving productivity, maximizing profits, harvesting the rewards and changing to suitable with other opportunities. 


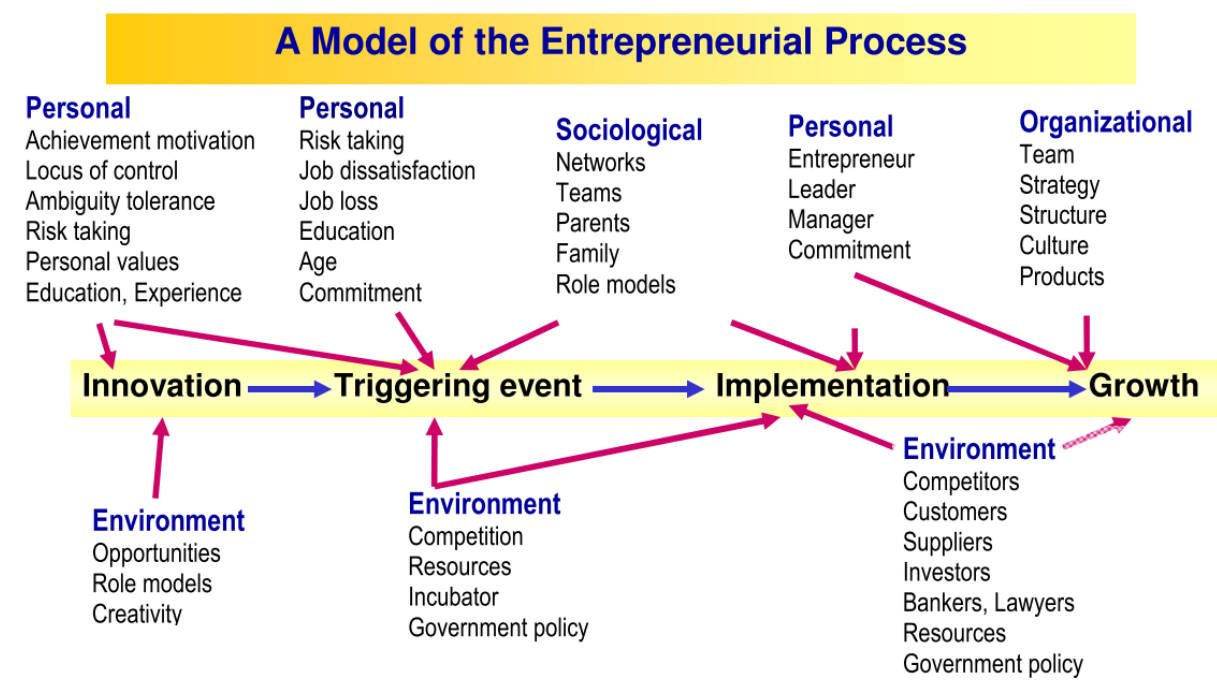

Source: Hisrich \& Peters $(2002: 48)$

Figure 5: The entrepreneurial process by Hisrich \& Peters.

Source: (Cronje et al., 2002)

Base on model of Grilo \& Thurik (2008), entrepreneurial process of Van der Zwan et al. includes five sequential stages: "never thought about starting a business", "thinking about starting a business", "taking steps to start a business", "running a business for less than three years", and "running a business for more than three years" (Van Der Zwan et al., 2013). Throughout the entrepreneurial process, like climbing a ladder, entrepreneurs are contributing value into economy and society.

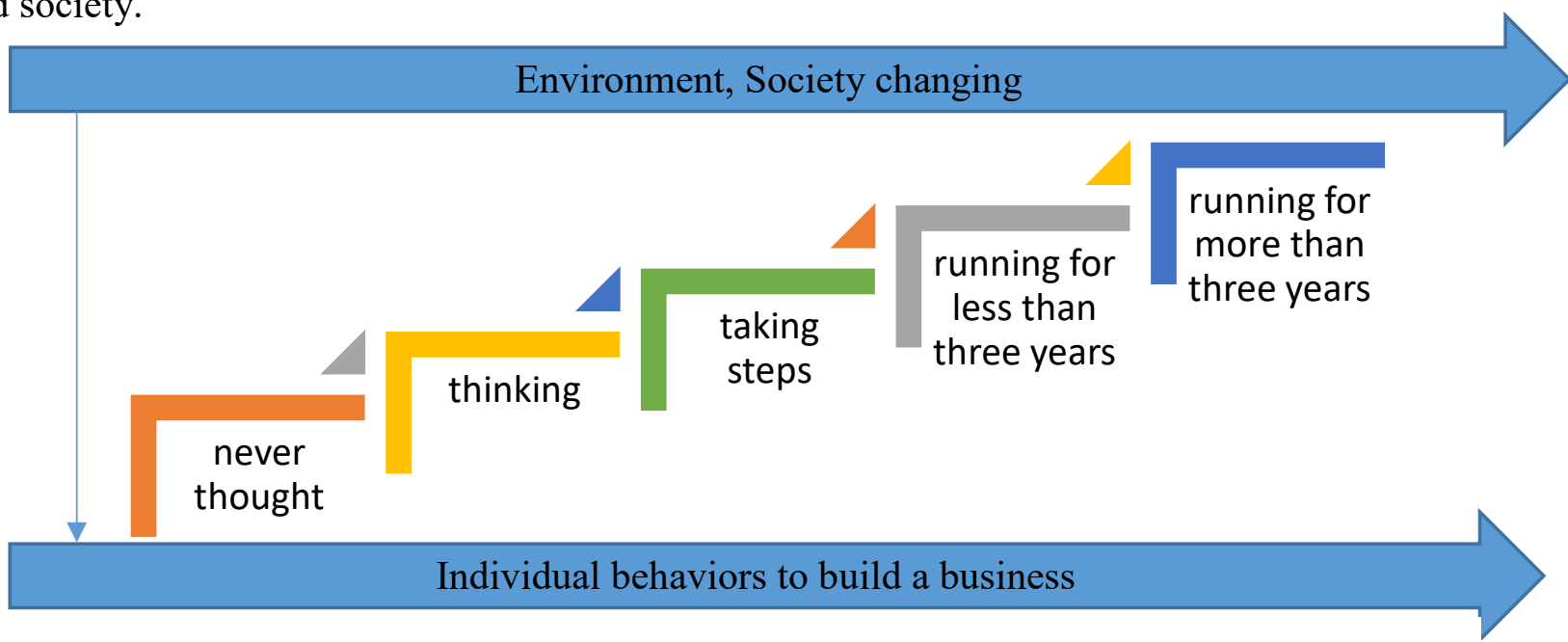

Figure 6: The entrepreneurial process by Van Der Zwan

Source: (Van Der Zwan et al., 2013)

Although the entrepreneurial models describe differences between the stages, in practice it is difficult to division each stage. All steps overlap, interact and depend on each other (Ardichvili et al., 2003). While understanding the each stage of entrepreneurial process, entrepreneurs can identify 
the necessary skills for success in that stage (Cronje et al., 2002). From that, policy maker or government can find what factors impact on entrepreneurial activities in order to have the suitable program to encourage entrepreneurship (Michael \& Phillipa, 2009; Rasmussen \& Gulbrandsen, 2012; Ribeiro-Soriano \& Galindo-Martín, 2012).

\subsection{Factors affecting entrepreneurship}

In addition to Krueger \& Brazeal, many studies in the world and in Vietnam focus on exploring what factors promote the intention or potential of student to become an entrepreneurs (Bui et al., 2018). The paradigms usually used are theory of planned behavior of Ajzen (1991),entrepreneurial event of Shapero and Sokol (1982) and social cognitive theory of Bandura (1986) (Quang \& Cuong, 2017). However, based on theory of Bruyat \& Julien, factors affecting entrepreneurship are appeared in whole process. That means, there is a need to discover what factors effect on entrepreneurs in "decision" stage.

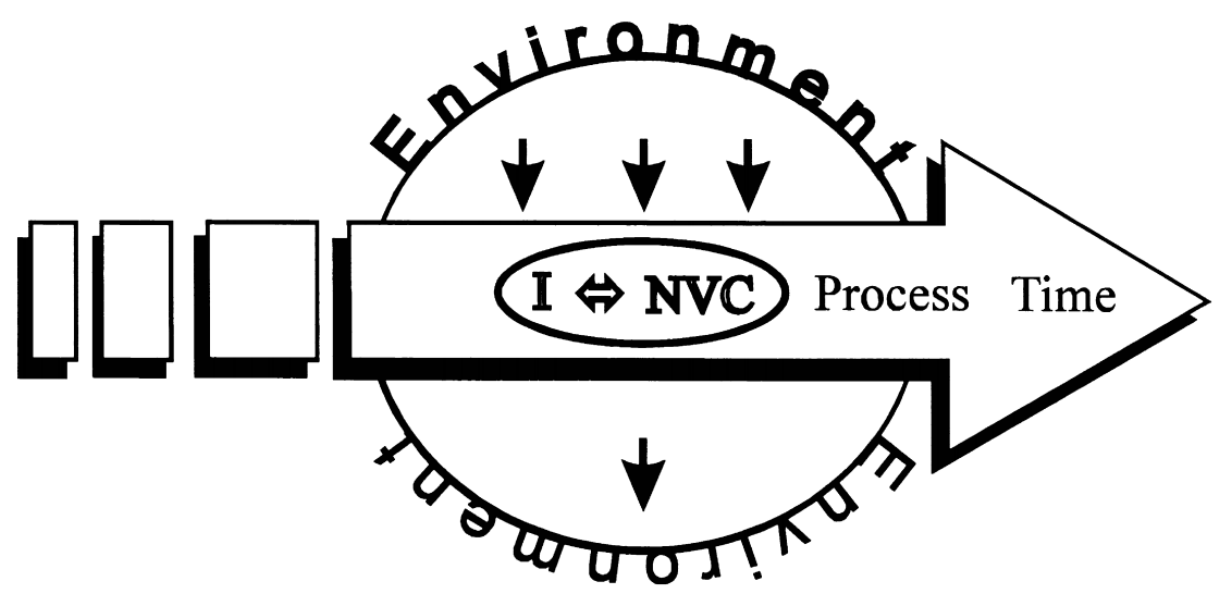

Figure 7: The entrepreneurial process located within its environment and time

Source: (Bruyat \& Julien, 2001)

All three above models are combined by the two entrepreneurial process of Gratner (Moroz \& Hindle, 2012) and Bruyat \& Julien (Bruyat \& Julien, 2001). The changing of person is influenced by both individual factors and environmental factors. In the other words, environment is one of important reason for entrepreneurial decision making. Study of Robinson et al. (2018) have the same viewpoint, entrepreneurship is created based on personal characteristics combined with the external environment. Similarly, Graevenitz et al. (2010) assume that there are two groups of factors affecting entrepreneurship - background factors and accompanying environment factors. Some researchers point out that individual behavior with specific personality traits and personal characteristics builds up entrepreneurship (Hian, 1996). 


\subsubsection{Individual factors}

Nobody can actually define what is an entrepreneur like and what his/her qualities and characteristics are (Mutisya, 2011). However, in many studies, people are listed by some traits or characteristics often found connected to entrepreneurial behavior. For example, in the trait approach, researchers explain an entrepreneurs being a person who can recognize opportunities, take risks, create and maintain their businesses to create sustainable values (Drucker, 2014; Loc, 2011; Shane, 2003). This would mean that entrepreneurs have abilities and functions as same as business people, but not all business owners are entrepreneurs (Carland et al., 1988; Huefner \& Flanagan, 1998; Miner \& Raju, 2004; Mutisya, 2011).

Brandstätter (2011); Driessen \& Zwart (2006); and Zhao \& Seibert (2006) point out the personality aspects of entrepreneurship and the results show influence of individual factors on entrepreneurs. Lüthje \& Franke (2003) found evidence that there is a correlation between entrepreneurial intentions for MIT students and personal characteristics, barriers and support factors. Mutisya (2011) also list some characteristics of entrepreneurs such as: versatile knowledge, dynamic leader, responsive to suggestions and criticism, good health. The similar characteristics of entrepreneurs are also described by Turker \& Selcuk (2009). Besides, the studies about personality traits of Lüthje \& Franke (2003); McClelland, (1986); Van Der Zwan et al. (2013) also show the influence of these factors on the formation of new businesses. The Brandstätter (2011) model results some indicators like being ready to innovate, being proactive, needing independence and controlling oneself that have a positive influence on business creation and successful business. Test results on personality traits and personal characteristics of Sharma \& Madan (2013) also illustrate the strong impact of these factors on Indian young entrepreneurial decision making.

From above articles, authors arrange individual factors into two groups. Firstly, personal characteristics are the qualities and characteristics of each person like technical qualification, management capacity, leadership ability, business experience, creativity and innovation and so on. Secondly, personality traits related to human psychology such as attitude (desire to achieve achievements and independence), cognitive behavioral control, subjective norms (confidence, taking risks, acumen and dynamic and so on).

\subsubsection{Environmental factors}

Abimbola \& Agboola (2011) argues that the important role of environmental factors is central to entrepreneurial activities. In the decision making process of entrepreneurs, not only individual factors are significant influencing factors, but environmental factors also play a contributing role (Suresh \& Ramraj, 2012). Study of Castaño et al. (2015) describe the correlation coefficients 
between economic and entrepreneurial indicators in whole European, Latin American and Caribbean countries. Entrepreneurial policies include law and supporting incentives as one of important factors affecting entrepreneurship (Stephen et al., 2005). In Iran, research of Jahanshahi et al., (2011) supplies to prove that education provides suitable foundation for developing entrepreneurship. However, environmental factors both encourage and discourage entrepreneurship (Lüthje \& Franke, 2003).

Research of Gorji \& Rahimian (2011) state that environmental barriers can stem inside from organization, such as lack of financial resources, relevant personnel, machinery and raw materials, and technology. Besides, external environmental factors including economy, law, rules and regulation, education and market, can also create challenges for creating and developing a business (Gorji \& Rahimian, 2011). Both Jafarnejad et al. (2013) and Jahanshahi et al., (2011) argue that internal finance, science - education and governmental policies are the main barriers of entrepreneurial development. In addition, entrepreneurs can face with other environmental barriers like competition with large existing companies (Kebaili et al., 2015); rules, regulation and administrative (Klapper et al., 2004; Samitowska, 2011; Wauters \& Lambrecht, 2008); bank interest rates and capital access requirements (Jahanshahi et al., 2011).

Both Feld (2012) and Suresh \& Ramraj (2012) believed that development of entrepreneurial communication is needed in contributing to an entrepreneurial ecosystems to support entrepreneurs. In exploring the applicability of the entrepreneurial ecosystems, nine principal factors are elaborated as the key components of creating a 'sustainable valley'. They are informal network, formal network, university, government, professional and support services, capital services and talent pool (Cohen, 2006). Moreover, Isenberg (2010) has proposed a model for ecosystem consisting of thirteen factors: leadership, government, culture, success stories, human capital, financial capital, entrepreneurial organizations, education, infrastructure, economic clusters, networks, support services, and customers. The stake holders include government, educational institutions, financial institutions, media and network (Isenberg, 2010). According to research of Global Entrepreneurship Monitor, the entrepreneurial ecosystem is analyzed based on twelve indicators: dynamics of the domestic market, culture and social norms, infrastructure, the openness of the domestic market, government policies, government regulations, technology transfer, business education at high school level, business support services, financial services for business, postsecondary Business, education, government assistance program ("Global Entrepreneurship Monitor Report 2017-2018,”2018). The score of each indicator represents the status of the business 
conditions of the surveyed area. From that, country or region can propose solutions to improve the limitations and facilitate business.

\subsubsection{Social - cultural factors}

In recent research, there has been a growing recognition that the social - cultural factors have a significant effect on the entrepreneurial process (Aidis et al., 2008; Gorji \& Rahimian, 2011; Liñán, 2004; Thornton et al., 2011; Welter \& Smallbone, 2011). The social - cultural factors can includes social recognition and support (Debroux, 2013; Korosec \& Berman, 2006); avoidance of uncertainty, individualism, masculinity and power distance (Thornton et al., 2011); social norms (Naser et al., 2009); institutions (Welter \& Smallbone, 2011) and so on.

Social - cultural environments have an effect on the performance of nascent entrepreneurs, because the entrepreneurs and their personal characteristics differ widely across communities' cultural contexts (Ribeiro-Soriano \& Galindo-Martín, 2012). Other research also point out that that municipalities help social entrepreneurs by increasing awareness of social problems, and by helping them to acquire resources, to coordinate with other organizations, and to implement programs (Korosec \& Berman, 2006). Furthermore, case studies of Urbano et al. (2011) shows the affection of two key social - cultural factors on emergence of entrepreneurship in Spain.

In the research about female entrepreneurs, Naser et al. (2009) point out social norms and social status are affecting on entrepreneurial decision making. Liñán (2004) also argue that the support from people around entrepreneurs can be a push factor for business decision. Comparison about female entrepreneurship in Asia, Debroux (2013) shows the significant influence of social support on female entrepreneurial development. However, some studies believe that social norms are not important factors because there is no relevance between social norms and entrepreneurial behaviors (Krueger et al., 2000; Liñán \& Chen, 2009).

Chand \& Ghorbani (2011) argue that differences in national culture has led to the establishment and management of businesses in different ways (financial management, control, staff training ...).

National culture also plays an important role in establishing and using social resources. Research of Anh et al. (2016) give evidence about effect of institution on entrepreneurial policies making. Having the same viewpoint, Welter and Smallbone emphasize the correlation between institutions and entrepreneurship, which means that institutions not only impact entrepreneurial behavior, but entrepreneurs also contribute to institutional change (Welter \& Smallbone, 2011).

In summary, social - cultural factors like social norms, institutions, tradition characteristics, social supports and so on, have an important role in entrepreneurial development. In other words, it 
illustrates how entrepreneurial behavior is linked to its social context (Welter \& Smallbone, 2011). Community is a key determinant of entrepreneurial success because the absence of empathy is likely to lead to non-effective entrepreneurship (Hindle, 2010).

\subsection{Hypotheses Development}

The results from the empirical studies above are able to explain $30 \%$ to $50 \%$ of the difference in entrepreneurial intentions, the remaining $50 \%$ of the differences are still not fully interpreted. The cause may be due to the relationship between the cognitive influences factors and intention to change depending on individual characteristics, family characteristics, contextual factors, as well as the study area (Fishbein \& Ajzen, 2011).

\subsubsection{Related studies}

There are two orientations for entrepreneurship research. Firstly, the focus in many studies on entrepreneurship is on factors affecting on potential and intention stage. This research direction usually uses quantitative method. Additionally, factors such as risk acceptation and fear of failure, environment and economy conditions, relational support and society support have been studied. The following table summarize factors affecting entrepreneurial intentions of students in some studies:

Table 2: Summary of entrepreneurial studies using quantitative approach

\begin{tabular}{|c|c|c|c|c|c|c|c|}
\hline \multirow{3}{*}{ Factors } & \multicolumn{7}{|c|}{ Authors } \\
\hline & $\begin{array}{l}\text { Pruett et } \\
\text { al., } \\
(2008)\end{array}$ & $\begin{array}{l}\text { Turker } \\
\quad \& \\
\text { Selcuk } \\
\text { (2009) }\end{array}$ & $\begin{array}{l}\text { Sandhu et } \\
\text { al. (2010) }\end{array}$ & $\begin{array}{c}\text { Iakovleva \& } \\
\text { Kolvereid } \\
(2011)\end{array}$ & $\begin{array}{l}\text { Quang } \\
\text { \& } \\
\text { Cuong } \\
\text { (2017) }\end{array}$ & $\begin{array}{c}\text { Loan et } \\
\text { al. } \\
\text { (2018) }\end{array}$ & $\begin{array}{c}\text { Tuan et } \\
\text { al. } \\
\text { (2019) }\end{array}$ \\
\hline & US & Turkey & Malaysia & $\begin{array}{c}\text { Developing } \\
\text { countries }\end{array}$ & Vietnam & Vietnam & Vietnam \\
\hline Attitude & $\mathrm{X}$ & $\mathrm{X}$ & & $X$ & $X$ & $X$ & $X$ \\
\hline $\begin{array}{l}\text { Social/ } \\
\text { Subjectives } \\
\text { norms }\end{array}$ & & $X$ & & & & $X$ & $X$ \\
\hline $\begin{array}{l}\text { Behavioral } \\
\text { control }\end{array}$ & & $X$ & & & & $X$ & $X$ \\
\hline $\begin{array}{l}\text { Desire for } \\
\text { success }\end{array}$ & $X$ & $\mathrm{X}$ & & & & & \\
\hline $\begin{array}{l}\text { Risk } \\
\text { acception }\end{array}$ & $X$ & & & $X$ & $X$ & & $X$ \\
\hline
\end{tabular}




\begin{tabular}{|c|c|c|c|c|c|c|c|}
\hline Creativity & & $\mathrm{X}$ & & & $\mathrm{X}$ & & \\
\hline Environment & & $\mathrm{X}$ & $\mathrm{X}$ & $\mathrm{X}$ & $\mathrm{X}$ & $\mathrm{X}$ & \\
\hline Education & & & $\mathrm{X}$ & & $\mathrm{X}$ & $\mathrm{X}$ & $\mathrm{X}$ \\
\hline $\begin{array}{l}\text { Society } \\
\text { support }\end{array}$ & $X$ & & $X$ & $X$ & $\mathrm{X}$ & & \\
\hline Culture & $\mathrm{X}$ & & & & $\mathrm{X}$ & & \\
\hline Demographic & & & & X & & & $\mathrm{X}$ \\
\hline
\end{tabular}

The second research orientation has been about finding the main barriers which prevent the starting of a new business through using a qualitative methodology. Many barriers listed relate to the environmental and social - cultural aspect. The following table summarize barriers of entrepreneurship development.

Table 3: Summary of entrepreneurial studies using qualitative approach

\begin{tabular}{|c|c|c|c|c|c|}
\hline \multirow{3}{*}{ Factors } & \multicolumn{5}{|c|}{ Authors } \\
\hline & $\begin{array}{l}\text { Robertson et al. } \\
\qquad(2003)\end{array}$ & $\begin{array}{c}\text { Carter \& } \\
\text { Wilton }(2006)\end{array}$ & $\begin{array}{l}\text { Chowdhury } \\
\text { (2007) }\end{array}$ & $\begin{array}{c}\text { Wauters \& } \\
\text { Lambrecht } \\
\text { (2008) }\end{array}$ & $\begin{array}{c}\text { Lockyer \& } \\
\text { George (2012) }\end{array}$ \\
\hline & UK & Zimbabwean & Bangladesh & Belgium & West Midlands \\
\hline $\begin{array}{l}\text { Negative } \\
\text { Attitude }\end{array}$ & $\mathrm{X}$ & $\mathrm{X}$ & & & $\mathrm{X}$ \\
\hline Finance & $\mathrm{X}$ & & $X$ & $\mathrm{X}$ & $X$ \\
\hline $\begin{array}{l}\text { Education } \\
\text { system }\end{array}$ & $X$ & & $\mathrm{X}$ & & $\mathrm{X}$ \\
\hline $\begin{array}{l}\text { National } \\
\text { culture }\end{array}$ & & $\mathrm{X}$ & $\mathrm{X}$ & $\mathrm{X}$ & \\
\hline $\begin{array}{l}\text { Legal and } \\
\text { regulatory }\end{array}$ & & & $\mathrm{X}$ & $\mathrm{X}$ & \\
\hline $\begin{array}{l}\text { Economic } \\
\text { and political } \\
\text { environment }\end{array}$ & & & $\mathrm{X}$ & $\mathrm{X}$ & \\
\hline Institution & & & & $X$ & \\
\hline
\end{tabular}




\begin{tabular}{|l|r|}
\hline Family & $\mathrm{X}$ \\
\hline Lack of time & \\
\hline Age & $\mathrm{X}$ \\
\hline
\end{tabular}

\subsubsection{Research questions}

Development of entrepreneurship is one of important target of many countries. However, the resources of countries to support entrepreneurs is limited. Government needs focus on one or few aspects to be received as having high effectiveness. In addition, based on literatures above, it is obvious that three groups: individual factors, environmental factors and social - cultural factors have impact on entrepreneurship. Nonetheless, different environmental contexts have their encouragements and barriers (Kebaili et al., 2015). For example, the entrepreneurial culture is different in every society (Chowdhury, 2007; Ozaralli \& Rivenburgh, 2016; Tuan et al., 2019). Research of Ozaralli \& Rivenburgh (2016) pointed out that cultural valuations of US creates an enormous advantages for entrepreneurship, while the cultural situation in Bangladesh is an obstacle for entrepreneurship development with corruption and political hooliganism (Chowdhury, 2007). To sum up, to minimize the disadvantages caused by barriers for entrepreneurs entering to the entrepreneurial markets, it is necessary to identify them (Robertson et al., 2003).

Furthermore, a lot of Vietnamese research has analyzed the issues regarding possible factors affecting on the entrepreneurial intention of students. However, they do not point out what are the barriers which entrepreneurs face. The only surveyed subjects are students who have many future career choices. Therefore, the prediction about their entrepreneurial behaviors in future is not certain (Pruett et al., 2008; Tuan et al., 2019). That is one of the research gaps related to entrepreneurship in Vietnam. With the studies finding barriers of entrepreneurs in the world, the qualitative methodology has been used. This method shows the results of a smaller group and thus the results cannot be generalized into a wider population. Hence, the studies finding barriers of entrepreneurs in the world are difficult to explain for Vietnamese entrepreneurs.

With above reasons, the purpose of this thesis is systematic some knowledge about entrepreneurship in Vietnam. The research will be carried out in Ho Chi Minh City with a focus on entrepreneurs' perceptions about factors influencing on entrepreneurship, including the entrepreneurial support policies of the government.

Main question of this research is: How to effective support for entrepreneurship in Ho Chi Minh City? 
To answer this question, research need point out the recent entrepreneurial barriers in Ho Chi Minh City. From that, the thesis can suggest some solutions to improve government's assistance. The following sub-questions will guide the research:

1. What factors influence on the development of entrepreneurship?

2. What is the impact level of each factors? Which factors have the strongest influence on entrepreneurship development?

\subsubsection{Research model}

Because in the previous studies, there are no suitable model to examine the influence of factors on entrepreneurship. Thus, I attempt to conduct a simple model based on the literature review described above. Three main group of factors is described as three hypotheses to test what factors have an effect on the decision of becoming an entrepreneur in Ho Chi Minh City.

In this thesis, the author assumes that these factors have a positive impact on entrepreneurship development. Through analysis of survey data, these hypotheses will be examined. The evaluation hypotheses also present the perception of respondents towards entrepreneurial current programs and policies.

The hypotheses are:

- H1: Individual factors positively influence on entrepreneurship development;

- H2: Environmental factors positively influence on entrepreneurship development;

- H3: Social - Cultural factors positively influence on entrepreneurship development.

This thesis will follow the model below:

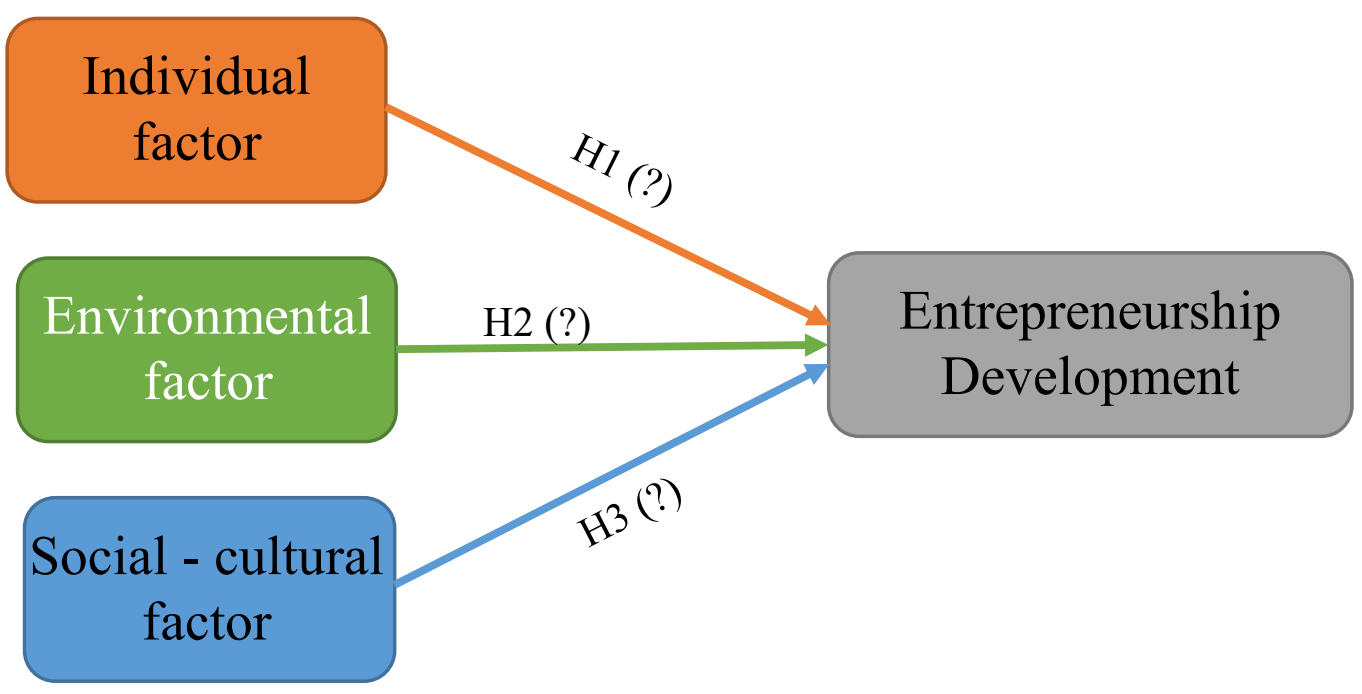

Figure 8: Conceptual model 


\section{Research methodology}

The purpose of this part is to point out the process the author has used in collecting the data. Furthermore, analysis methods are also described.

\subsection{Research procedure}

This study was conducted by using a quantitative methods. The data was collected by online questionnaire and the analysis was done by utilizing statistical methods. The research process was carried out in two stages: initial test (pilot test) and official research (Lin and Wang, 2006). In the initial research phase, based on theoretical framework, the author designed the questionnaire to build a preliminary scale of factors affecting entrepreneurship. After being collected, the reliability and value of construction scales of the data were assessed. At the formal stage, quantitative research methods were used for testing scales, measuring the influence of factors, and testing hypotheses with support of SPSS 20.0 software.

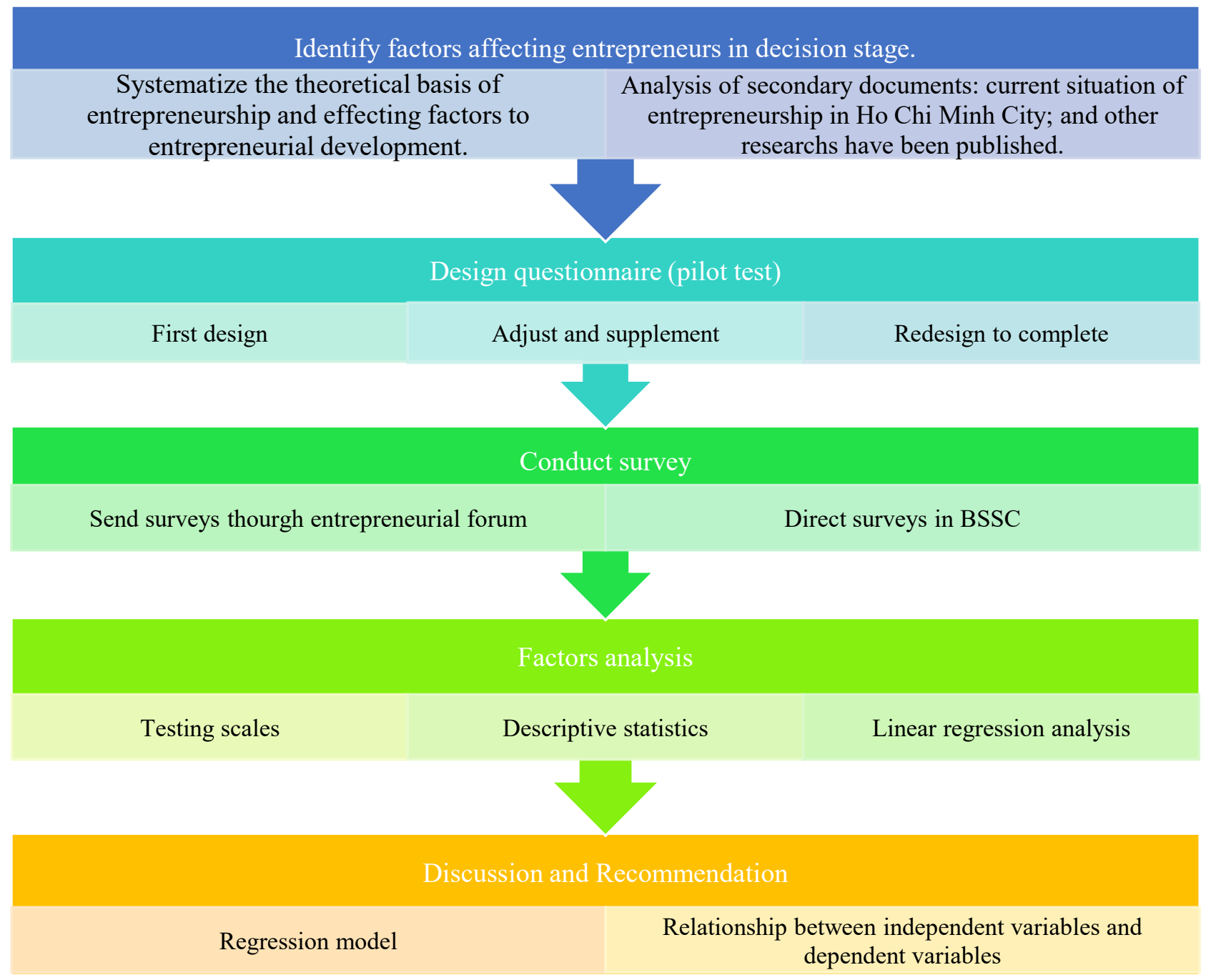

Figure 9: Research process 


\subsection{Measurement scales}

Based on the literature review and hypotheses development, the author structured the questionnaire with 20 observed variables, which were inherited from previous research and then improved to this measurement scale to suit the aims of the thesis, including statements about individual factors ( 5 questions), environmental factors (5 questions), social - culture factors (5 questions) and entrepreneurship development (5 questions). Detail of questionnaire is presented in table 4 below. The questions were modified and translated to English, then converted into Vietnamese version for delivery to respondents. The type of scale used for measuring the observed boundaries in the research model is Likert 5-point scale which shows from small to large agreeing with the statement (1: strongly disagree, 2: disagree, 3: neutral, 4: agree, 5: strongly agree). This type of scale is used often when studying sociological behavior.

In this thesis, entrepreneurship is defined as an aspect of personal psychology (Loc, 2011). It includes entrepreneurial traits like: innovation and creation, risk acceptation, achievement need and sustainable target. The questions are created to estimate the level of each entrepreneurial traits. That means when respondents choose higher agree with statement sentence, the level of entrepreneurship development is higher.

In term of individual factors, the author attempts to describe characteristics of a complete entrepreneurship (Dewett, 2007; Walton, 2003). Respondents will evaluate level of agreement with each necessary characteristic for one entrepreneurship. The statement sentence has much agreement is a significant item in the individual factors.

With measuring environmental factors, each statement sentence presents as a convenience of environmental factors, including: accessing finance, finding information, finding partners, government's assistance and education training. Agreement of respondents with statement sentence illustrates their thinking about environmental factors. Hence, with someone, some factors can be positive, but with other, they are not.

The social - cultural statement sentences are described as the positive attitude of Vietnamese society and culture with entrepreneurship. Agreement with these identifications is considered to be a favorable level of social - cultural factors to develop entrepreneurship. 
Table 4: The measurement scales

\begin{tabular}{|c|c|c|c|}
\hline \multirow{5}{*}{$\begin{array}{l}\text { Entrepreneurship } \\
\text { development } \\
(\mathrm{BE})\end{array}$} & BE 1 & Your vision is to become an entrepreneur. & \multirow{5}{*}{$\begin{array}{l}\text { (Tuan et al., 2019) } \\
\text { (Loan et al., 2018) } \\
\text { (Pruett et al., } \\
2008 \text { ) }\end{array}$} \\
\hline & BE 2 & $\begin{array}{l}\text { You can accept the risk and failure in } \\
\text { business }\end{array}$ & \\
\hline & BE 3 & $\begin{array}{l}\text { You are confident that you have enough } \\
\text { abilities to become an entrepreneur }\end{array}$ & \\
\hline & BE 4 & $\begin{array}{l}\text { You recognize opportunities and have ideas } \\
\text { for business }\end{array}$ & \\
\hline & BE 5 & $\begin{array}{l}\text { You have knowledge and experiment to } \\
\text { become an entrepreneur. }\end{array}$ & \\
\hline \multirow{5}{*}{$\begin{array}{l}\text { Individual factor } \\
\text { (IN) }\end{array}$} & IN 1 & $\begin{array}{l}\text { When there is a lack of entrepreneurial } \\
\text { passion, business will be a failure. }\end{array}$ & \multirow{5}{*}{$\begin{array}{l}\text { (Dewett, 2007) } \\
\text { (Walton, 2003) }\end{array}$} \\
\hline & IN 2 & $\begin{array}{l}\text { The ability to connect business with markets } \\
\text { and customers is extremely important. }\end{array}$ & \\
\hline & IN 3 & $\begin{array}{l}\text { Entrepreneurs need the combined } \\
\text { knowledge and skills of manager and } \\
\text { leader. }\end{array}$ & \\
\hline & IN 4 & $\begin{array}{l}\text { The sustainable value is the goal of } \\
\text { entrepreneurs. }\end{array}$ & \\
\hline & IN 5 & $\begin{array}{l}\text { Experiences are the foundation for a } \\
\text { successful entrepreneur. }\end{array}$ & \\
\hline \multirow{4}{*}{$\begin{array}{l}\text { Environmental } \\
\text { factor }(\mathrm{EN})\end{array}$} & EN 1 & $\begin{array}{l}\text { Accessing and maintaining capital to start a } \\
\text { business is currently accessible. }\end{array}$ & \multirow{4}{*}{$\begin{array}{l}\text { (Abimbola \& } \\
\text { Agboola, 2011) } \\
\text { (Sesen, 2012) }\end{array}$} \\
\hline & EN 2 & $\begin{array}{l}\text { Finding information about starting a } \\
\text { business and giving information to others is } \\
\text { simple. }\end{array}$ & \\
\hline & EN 3 & $\begin{array}{l}\text { Finding partners or recruitment of human } \\
\text { resources are not challenged. }\end{array}$ & \\
\hline & EN 4 & $\begin{array}{l}\text { Entrepreneurial policies and laws associated } \\
\text { with entrepreneurship (like administrative }\end{array}$ & \\
\hline
\end{tabular}




\begin{tabular}{|c|c|c|c|}
\hline & & $\begin{array}{l}\text { procedures, intellectual property protection, } \\
\text { and tax) have created many favorable } \\
\text { conditions for startups. }\end{array}$ & \\
\hline & EN 5 & $\begin{array}{l}\text { Education provides the necessary } \\
\text { knowledge and promotes skill development } \\
\text { for students to become businesses. }\end{array}$ & \\
\hline \multirow{5}{*}{$\begin{array}{l}\text { Social - Cultural } \\
\text { factor (SC) }\end{array}$} & SC 1 & $\begin{array}{l}\text { Family and friends will support your } \\
\text { entrepreneurship. }\end{array}$ & \multirow{5}{*}{$\begin{array}{l}\text { (Liñán \& Chen, } \\
\text { 2009) } \\
\text { (Turker \& Selcuk, } \\
\text { 2009) } \\
\text { (Thornton et al., } \\
\text { 2011) }\end{array}$} \\
\hline & $\mathrm{SC} 2$ & $\begin{array}{l}\text { Society has many support systems for } \\
\text { entrepreneurial development. }\end{array}$ & \\
\hline & SC 3 & $\begin{array}{l}\text { Multimedia communication provides many } \\
\text { promotion possibilities for entrepreneurs. }\end{array}$ & \\
\hline & $\mathrm{SC} 4$ & $\begin{array}{l}\text { Entrepreneurship is an ideal job and } \\
\text { receives a lot of admiration. }\end{array}$ & \\
\hline & SC 5 & $\begin{array}{l}\text { "Start-up" contests have attracted much } \\
\text { public attention. }\end{array}$ & \\
\hline
\end{tabular}

\subsection{Research data}

This study was conducted in Ho Chi Minh City, Vietnam. In addition, for being dynamic and thriving, the city has the large number of entrepreneurs as well as entrepreneurial activities. In order to ensure that the collected data is reliable and valid, the author conducted the sampling of research subjects from entrepreneurs using services at the support center BSSC. Participants were contacted with a web survey. Furthermore, the author also randomly distributed the web-based questionnaires to some entrepreneurial groups. The convenience sampling method (non-probability) is used because of low cost and due to time constraints.

Quantitative analysis often requires large sample sizes. However, the required size of the sample is not always consistent in previous research. For the accuracy of data analysis, Hair et al., (2010) suggest that the number of measurement variables determines the sample size. The minimum sample size needs to be 50 or more and the observed / measurement ratio needs to be 5:1 (Hair et al. , 2010). This means that a minimum of 5 observations are required for a single measurement variable. This thesis consists of 20 items in measurement scale; which means that the sample size is required to be at least 100 observations. In addition, the number of sample size must respond to the 
multiple regression analysis following the formula of Tabachnick \& Fidell (2006): $n=50+8 m$ (which $\mathrm{m}$ is the number of independent variables). Therefore, three independent variables and one dependent variable in this study need 74. In short, the number of samples is expected in this thesis is 100 surveys.

\subsection{Data analysis methods}

Thesis use quantitative research approach in conducting the research. Primary data were collected from surveys analyzed using the SPSS software. At the pilot test, the scale is preliminarily assessed with reliability for small sample sizes. In the formal stage, statistical analysis techniques were conducted including:

- Cronbach's Alpha and Corrected item-total correlation test to evaluate the reliability of the scales. In the researcher Hair et al., (2010), the Cronbach's Alpha coefficient is accepted at greater than 0.6. Follow the research Pallant (2011), Cronbach's Alpha coefficient has a marginal value in the cavity $[0,1]$ where Cronbach's Alpha is as high as possible because it reflects a high confidence level. However, Cronbach's Alpha coefficient should not be too high (higher than 0.95) because it shows the indifference of scale which means that they measure the same content. Hence, the standard acceptable Cornbrash's Alpha's is 0.7 (Pallant, 2011; Tavakol \& Dennick, 2011). In addition to the Cronbach's Alpha coefficient, the sub-thesis examines whether the correlationcorrective coefficient of adjustment and the observation margins in each study concept are closely related. This coefficient correlates the measurement variable with the sum of the remaining variables of the scale (excluding the variable under consideration). If a measurement boundary has a corrected-boundary correlation coefficient $\geq 0.3$, the boundary is satisfactory. Thus, a scale that is considered to meet the requirements has a Cronbach's Alpha coefficient $\geq 0.7$ and the observed variables meet the requirements to measure a concept with (Corrected item-total correlation) $\geq 0.3$.

- Exploratory Factor Analysis (EFA) were conducted to evaluate the convergent and discriminant validity of the scales. Factor analysis will help to shorten from a set of many observed variables into fewer potential variables while still explaining the research data (Hair et al., 2010). Because the analysis is done for each factor, the writer chooses the method of extracting the main component (Principal Component Analysis) with varimax rotation to get the largest variance. In this step, the thesis only considers variables with factor loading to be higher than 0.5; KMO coefficients of factors in the model to be larger than 0.5 indicate that factor analysis is appropriate; Bartlett's test with p-value to be smaller than 0.05 , shows the observed variables correlated with each other in the whole and the variance explains the factors must be higher than $50 \%$, that means factor analysis explains more than 50\% situations (Creswell, 2014). 
- Correlation analysis is a statistical indicator that measures the correlation between two variables, including between each independent variable and the dependent variable, and among the independent variables. The correlation coefficient has a value between -1 and 1 (Polonsky \& Waller, 2015). A correlation coefficient of 0 (or near 0 ) means that the two variables are not related to each other; conversely if a coefficient of -1 or 1 means the two variables have an absolute relationship. The value can show positive relationship or negative relationship. In detail, the value of the correlation coefficient is negative $(r<0)$, it means that when one of two variable considered increases and the other decreases (similarly, when the one decreases, the other increases). The correlation coefficient value is positive ( $r>0$ ), it means that when the one increases, the other increases, and when the one decreases, the other also decreases. The correlation coefficient Pearson (r) is only significant if and only if the observed significance level (sig.) is less than the significance level $\alpha$. In this thesis, the author choose $\alpha$ is $5 \%(0.05)$.

- Linear regression analysis to determine the impact of factors on entrepreneurship development. In other words, linear regression is a method to predict the dependent variable (Y) based on the value of the independent variable (X). A linear regression line has an equation of the form, with independent variables (known as explanatory variables), are denoted by $\mathrm{X}$; and $\mathrm{Y}$ is a notation of the dependent variable. The relationship coefficient between $\mathrm{X}$ and $\mathrm{Y}$ is $\mathrm{b}$, and $\mathrm{a}$ is the constant (the value of $\mathrm{y}$ when $\mathrm{x}=0$ ). The simple model is described:

$$
\mathbf{Y}=\mathbf{a}+\mathbf{b}_{1} \mathbf{X}_{1}+\mathbf{b}_{2} \mathbf{X}_{2}+\mathbf{b}_{3} \mathbf{X}_{3}
$$

With: Y - Entrepreneurship Development

$$
\begin{aligned}
& \mathrm{X}_{1}-\text { Individual factors } \\
& \mathrm{X}_{2}-\text { Environmental factors } \\
& \mathrm{X}_{3}-\text { Social - cultural factors }
\end{aligned}
$$




\section{Data analysis}

\subsection{Sample description}

Survey subjects are people who have had a plan to become entrepreneurs in Ho Chi Minh City. The author sent approximately 100 questionnaires for people in BSSC and post survey link to five entrepreneurial forums. The total number of questionnaires collected is 154 , the total number of usable responses is 154 .

In the questionnaire, four questions were asked to find out the basic information of entrepreneurs including gender, age, education level and reason to start the enterprise. These descriptive variables serve as a basis for comparison between groups to find differences due to the impact of demographic variables.

The number of females participating in the survey is higher than that of male. While $54.55 \%$ of the respondents are female, male account for only $45.45 \%$. It is same as with report in $2017-2018$ of GEM (“Global Entrepreneurship Monitor Report 2017-2018,” 2018), percentage of female taking part in the entrepreneurship is higher than male.

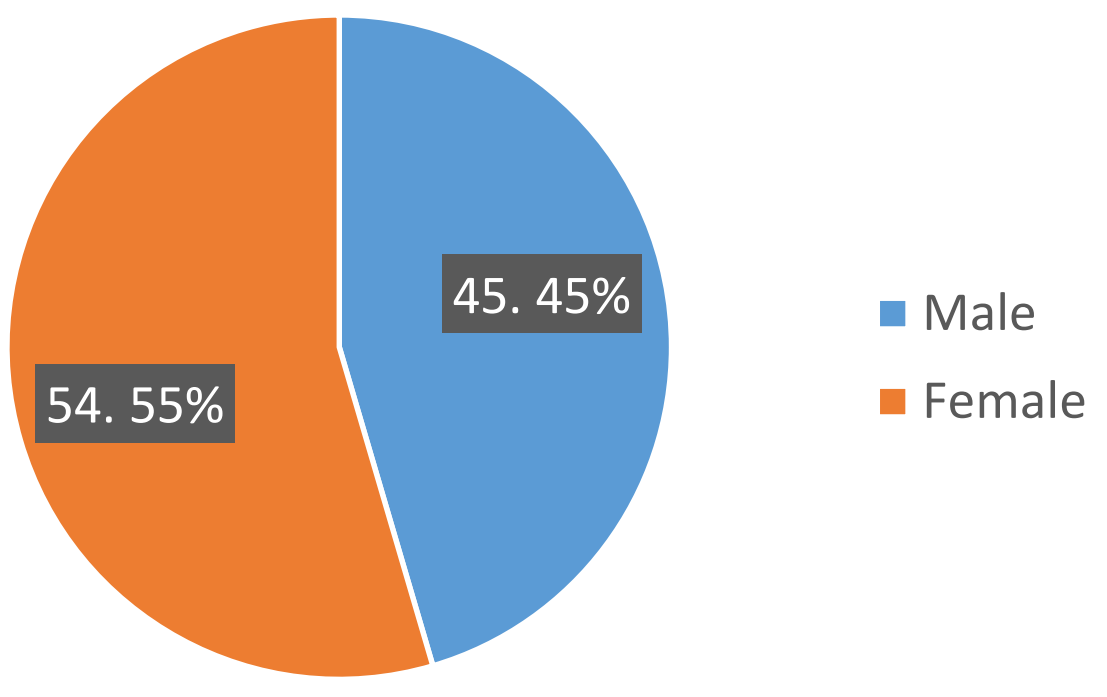

Figure 10: Gender of respondents

From the figure 11, it can be seen that the majority of entrepreneurs in the initiated stage are aged 22 to 34 years old, accounting for 74 percent, followed by those over 34 years old (16.88\%), and younger than 22 years old (9.09\%) This reflects the fact that the average age of the entrepreneurs, 22 to 34 years old, is a balanced age that has the knowledge, experience, agility and 
adventurousness to start a business. While in term of the group over 34 years old, people prefer a stable life instead of changes and challenges, which can be depicted as culturally characteristic in Vietnam.

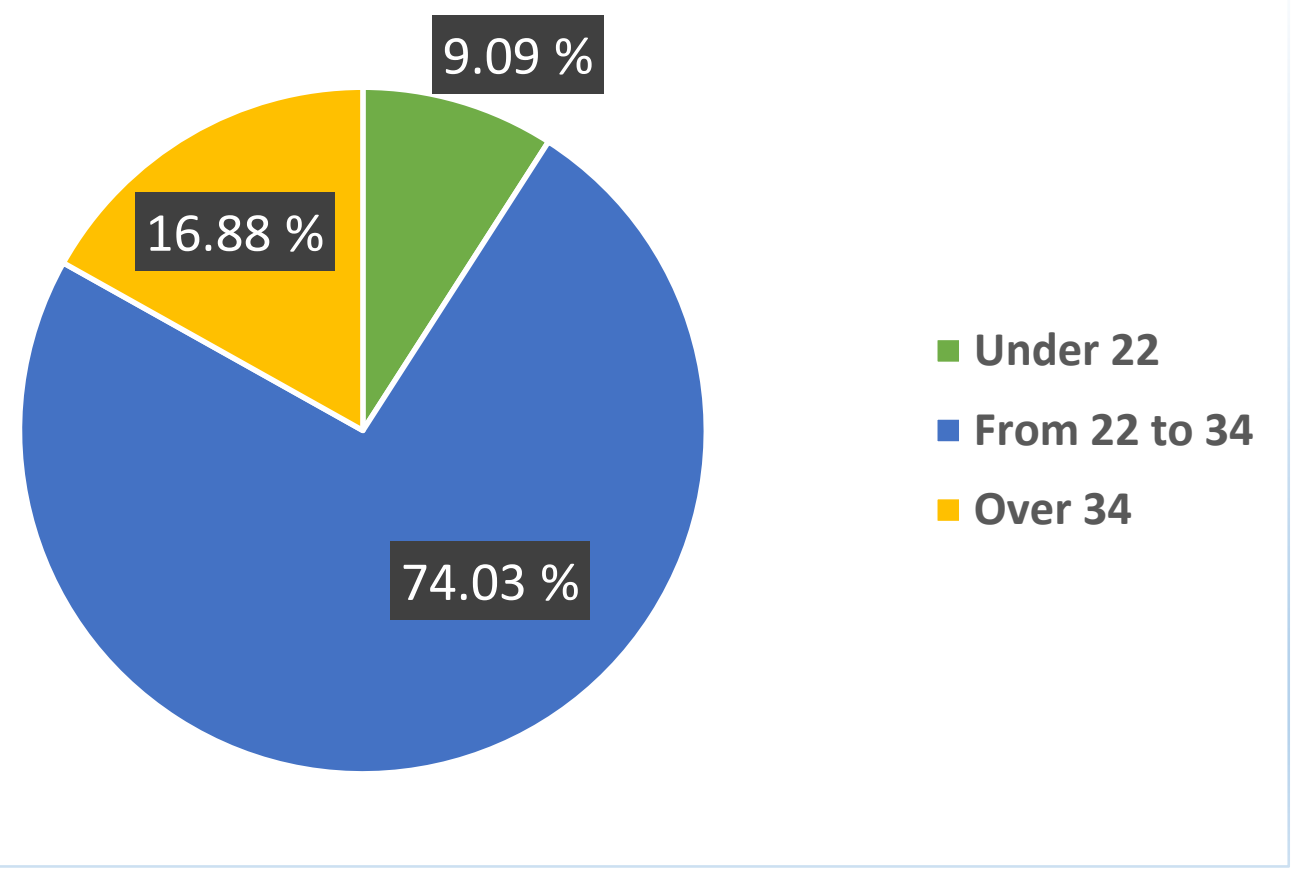

Figure 11: Age of respondents

Concerning educational background, the majority of the respondents graduated from university and are postgraduates, accounting for $90.91 \%$ from the total. While respondents from other educational background are relatively small group, with only $9.09 \%$ in term of no university level studies, who do not learn university or college, they just graduate high school. This finding is also not surprising as it requires to having a certain amount of knowledge, skills and experience to become an entrepreneur. Besides, respondents of this research is entrepreneurs are in the initial phase of becoming an entrepreneur and are looking for resources to conduct the project. 


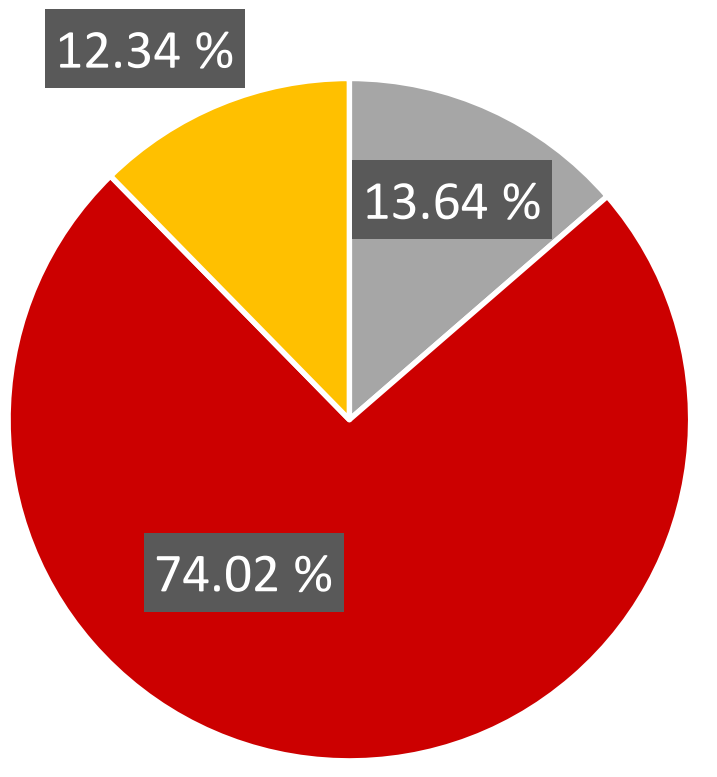

No university level studies

- University

- Postgraduate

Figure 12: Education level of respondents

The figure 13 shows out the reasons of the respondents to becoming an entrepreneur. There are 51 participants who chose both three reasons: improving finance, following passion and having an opportunity. While respondents chose improving finance is 54 persons, it was 25 and 24 persons who particularly chose the reason "following passion" and "having an opportunity". In consequence, the major purpose of becoming an entrepreneur is to improve finance, $41 \%$, while both percentages of following passion and having an opportunity is approximate $30 \%$. The result is similar to motivation index of Vietnamese entrepreneurship statistic ("Global Entrepreneurship Monitor Report 2017-2018," 2018). This shows that Vietnamese people engaged in business are still largely influenced by income-boosting motives. In other word, Vietnamese entrepreneurial system is still on the first stage of entrepreneurial development. It also reflects the fact that the creativity level of Vietnamese entrepreneurship is low, comparing with the developed countries. Reason for this situation is the need of people to find profitable business model. 


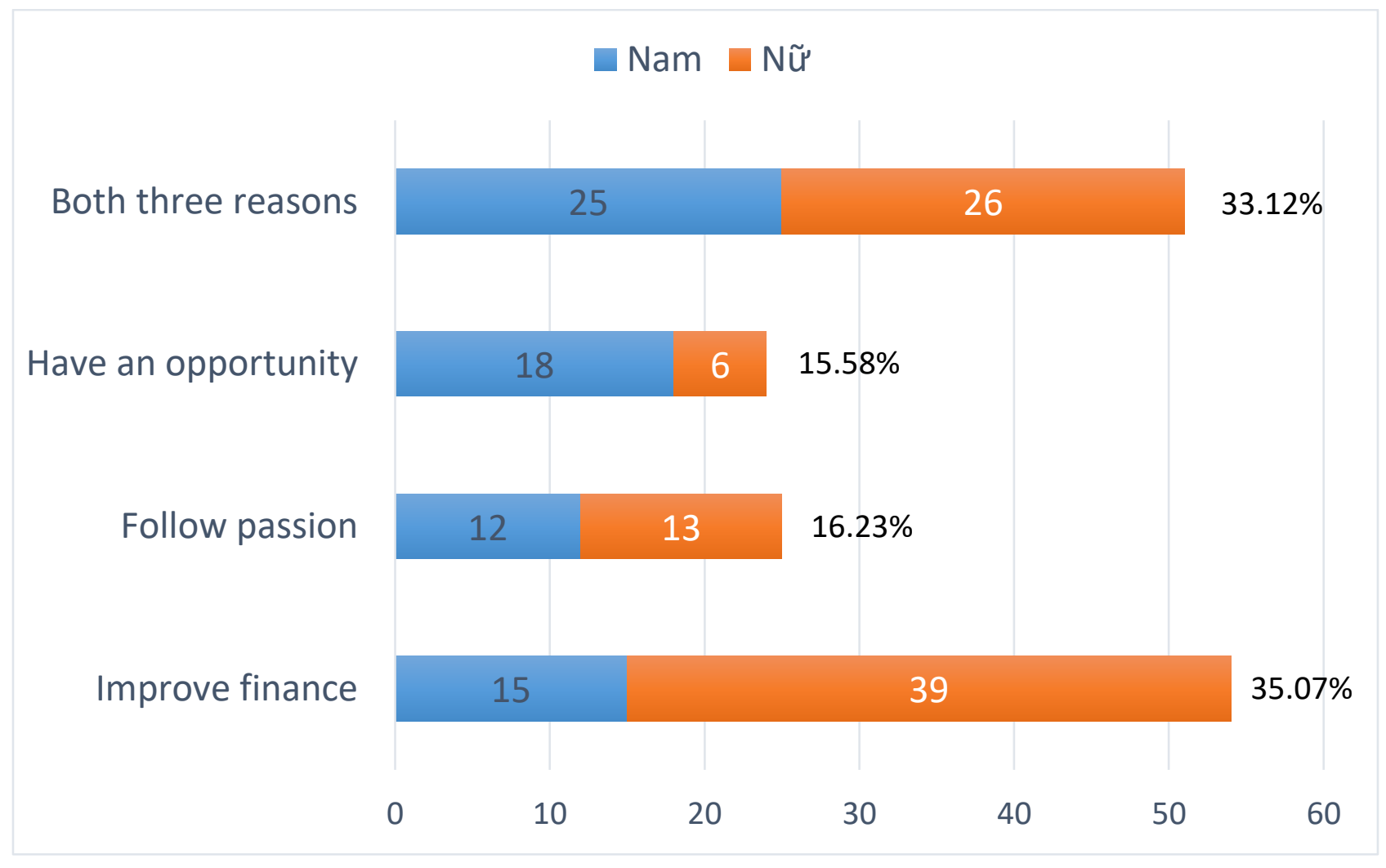

Figure 13: Reason to be entrepreneurs of respondents

Comparing the percentages of female and male to join entrepreneurship, in term of starting business to improve finance, female percentage is higher than male (female is 39 responds and male is 15). While in the reason "having an opportunity", the result is reverse, with 6 female responds and 18 male responds. This suggests that Vietnamese women engage in business due to financial requirements rather than actively taking advantage of opportunities, which will affect their business results. This makes reasonable sense for small and micro business of Vietnamese female entrepreneurs, which is mainly commercial businesses and have the narrow business scope.

\subsection{Efficiency}

Descriptive analysis is performed with four groups of both dependent and independent variables, the purpose of this analysis is to check if entire values follow normal distribution. The sample size is 154 .

Frequencies analysis of entrepreneurship development, almost all respondents (89\%) does not completely agree with the goal to become an entrepreneurs, the mean value of BE 1 is 3.47. This result is also the same for other items which measure entrepreneurship development. The mean values of $\mathrm{BE} 2, \mathrm{BE} 3, \mathrm{BE} 4$ and $\mathrm{BE} 5$ is 3.44, 3.49, 3.58 and 3.51 respectively. This statistics shows that the attitude of respondents is quite unconfident about their entrepreneurial ability. 
Table 5: Description of respondents about entrepreneurial characteristics in themselves.

\begin{tabular}{|c|c|c|c|c|c|c|c|c|}
\hline \multirow[b]{2}{*}{ Item } & \multirow[b]{2}{*}{ Content } & \multicolumn{5}{|c|}{ Frequencies } & \multirow[b]{2}{*}{ Mean } & \multirow{2}{*}{$\begin{array}{c}\text { Std. } \\
\text { Deviation }\end{array}$} \\
\hline & & $\begin{array}{l}\text { Strongly } \\
\text { disagree }\end{array}$ & Disagree & Neutral & Agree & $\begin{array}{c}\text { Strongly } \\
\text { agree }\end{array}$ & & \\
\hline \multirow{2}{*}{ BE 1} & \multirow{2}{*}{$\begin{array}{l}\text { Your vision is to } \\
\text { become an } \\
\text { entrepreneur. }\end{array}$} & 0 & 8 & 74 & 63 & 9 & \multirow{2}{*}{3.47} & \multirow{2}{*}{.688} \\
\hline & & $0 \%$ & $5.2 \%$ & $48.1 \%$ & $40.9 \%$ & $5.8 \%$ & & \\
\hline \multirow[b]{2}{*}{ BE 2} & \multirow{2}{*}{$\begin{array}{l}\text { You can accept } \\
\text { the risk and failure } \\
\text { in business. }\end{array}$} & 0 & 13 & 70 & 61 & 10 & \multirow[b]{2}{*}{3.44} & \multirow[b]{2}{*}{.741} \\
\hline & & $0 \%$ & $8.4 \%$ & $45.5 \%$ & $39.6 \%$ & $6.5 \%$ & & \\
\hline \multirow[b]{2}{*}{ BE 3} & \multirow{2}{*}{$\begin{array}{l}\text { You are confident } \\
\text { that you have } \\
\text { enough abilities to } \\
\text { become an } \\
\text { entrepreneur. }\end{array}$} & 0 & 3 & 90 & 44 & 17 & \multirow[b]{2}{*}{3.49} & \multirow[b]{2}{*}{.716} \\
\hline & & $0 \%$ & $1.9 \%$ & $58.4 \%$ & $28.5 \%$ & $11.0 \%$ & & \\
\hline \multirow[b]{2}{*}{ BE 4} & \multirow{2}{*}{$\begin{array}{l}\text { You recognize } \\
\text { opportunities and } \\
\text { have ideas for } \\
\text { business. }\end{array}$} & 0 & 4 & 73 & 60 & 17 & \multirow[b]{2}{*}{3.58} & \multirow[b]{2}{*}{.720} \\
\hline & & $0 \%$ & $2.6 \%$ & $47.4 \%$ & $39.0 \%$ & $11.0 \%$ & & \\
\hline \multirow[b]{2}{*}{ BE 5} & \multirow{2}{*}{$\begin{array}{l}\text { You have } \\
\text { knowledge and } \\
\text { experiment to } \\
\text { become an } \\
\text { entrepreneur. }\end{array}$} & 0 & 8 & 73 & 59 & 14 & \multirow[b]{2}{*}{3.51} & \multirow[b]{2}{*}{.734} \\
\hline & & $0 \%$ & $5.2 \%$ & $47.4 \%$ & $38.3 \%$ & $9.1 \%$ & & \\
\hline
\end{tabular}

Table 6 present the opinion of participants about personal requirements to become an entrepreneur. $71.4 \%$ agree that passion is not extremely important for becoming an entrepreneur. Besides, over $50 \%$ of answers show that the sustainable values is not the goal of entrepreneurs. Approximate $50 \%$ participants think skills and knowledge factor (IN 4) is a significant personal element for entrepreneurs.

Table 6: Description of respondents about individual characteristics of entrepreneur.

\begin{tabular}{|c|c|c|c|c|c|c|c|c|}
\hline \multirow[b]{2}{*}{ Item } & \multirow[b]{2}{*}{ Content } & \multicolumn{5}{|c|}{ Frequencies } & \multirow[b]{2}{*}{ Mean } & \multirow{2}{*}{$\begin{array}{c}\text { Std. } \\
\text { Deviation }\end{array}$} \\
\hline & & $\begin{array}{l}\text { Strongly } \\
\text { disagree }\end{array}$ & Disagree & Neutral & Agree & $\begin{array}{c}\text { Strongly } \\
\text { agree }\end{array}$ & & \\
\hline \multirow[b]{2}{*}{ IN 1} & \multirow{2}{*}{$\begin{array}{l}\text { When there is a } \\
\text { lack of } \\
\text { entrepreneurial } \\
\text { passion, business } \\
\text { will be a failure. }\end{array}$} & 0 & 21 & 110 & 23 & 0 & \multirow[b]{2}{*}{3.01} & \multirow[b]{2}{*}{.536} \\
\hline & & $0 \%$ & $13.6 \%$ & $71.4 \%$ & $14.9 \%$ & $0 \%$ & & \\
\hline \multirow[b]{2}{*}{ IN 2} & \multirow{2}{*}{$\begin{array}{l}\text { The ability to } \\
\text { connect business } \\
\text { with markets and } \\
\text { customers is } \\
\text { extremely } \\
\text { important. }\end{array}$} & 0 & 8 & 98 & 44 & 4 & & \\
\hline & & $0 \%$ & $5.2 \%$ & $63.6 \%$ & $28.6 \%$ & $2.6 \%$ & 3.29 & .602 \\
\hline
\end{tabular}




\begin{tabular}{|c|c|c|c|c|c|c|c|c|}
\hline \multirow[b]{2}{*}{ IN 3} & \multirow{2}{*}{$\begin{array}{l}\text { Entrepreneurs } \\
\text { need the combined } \\
\text { knowledge and } \\
\text { skills of manager } \\
\text { and leader. }\end{array}$} & 0 & 29 & 49 & 67 & 9 & \multirow[b]{2}{*}{3.36} & \multirow[b]{2}{*}{.854} \\
\hline & & $0 \%$ & $18.8 \%$ & $50.6 \%$ & $43.3 \%$ & $5.8 \%$ & & \\
\hline \multirow[b]{2}{*}{ IN 4} & \multirow{2}{*}{$\begin{array}{l}\text { The sustainable } \\
\text { value is the goal of } \\
\text { entrepreneurs. }\end{array}$} & 54 & 46 & 25 & 27 & 2 & \multirow[b]{2}{*}{2.20} & \multirow[b]{2}{*}{1.140} \\
\hline & & $35.1 \%$ & $29.9 \%$ & $16.2 \%$ & $17.5 \%$ & $1.3 \%$ & & \\
\hline \multirow[b]{2}{*}{ IN 5} & \multirow{2}{*}{$\begin{array}{l}\text { Experiences are } \\
\text { the foundation for } \\
\text { a successful } \\
\text { entrepreneur. }\end{array}$} & 0 & 15 & 79 & 53 & 7 & \multirow[b]{2}{*}{3.34} & \multirow[b]{2}{*}{.716} \\
\hline & & $0 \%$ & $9.7 \%$ & $51.3 \%$ & $34.4 \%$ & $4.5 \%$ & & \\
\hline
\end{tabular}

Regarding entrepreneurial environment, about $70 \%$ agree that there is difficulty to find and maintain business's capital and human resources. Nearly $30 \%$ of survey respondents said that education does not provide sufficient amount of entrepreneurial knowledge for learners. While support of government factors is identified as favorable (approximate 75\% of answers). Similarly, finding information about entrepreneurship is moderately easy.

Table 7: Description of respondents about environmental business

\begin{tabular}{|c|c|c|c|c|c|c|c|c|}
\hline \multirow[b]{2}{*}{ Item } & \multirow[b]{2}{*}{ Content } & \multicolumn{5}{|c|}{ Frequencies } & \multirow[b]{2}{*}{ Mean } & \multirow{2}{*}{$\begin{array}{c}\text { Std. } \\
\text { Deviation }\end{array}$} \\
\hline & & $\begin{array}{l}\text { Strongly } \\
\text { disagree }\end{array}$ & Disagree & Neutral & Agree & $\begin{array}{c}\text { Strongly } \\
\text { agree }\end{array}$ & & \\
\hline \multirow[b]{2}{*}{ EN 1} & \multirow{2}{*}{$\begin{array}{l}\text { Accessing and } \\
\text { maintaining } \\
\text { capital to start a } \\
\text { business is } \\
\text { currently } \\
\text { accessible. }\end{array}$} & 10 & 19 & 72 & 52 & 1 & & \\
\hline & & $6.5 \%$ & $12.3 \%$ & $46.8 \%$ & $33.8 \%$ & $0.6 \%$ & 3.10 & .861 \\
\hline \multirow[b]{2}{*}{ EN 2} & \multirow[b]{2}{*}{$\begin{array}{l}\text { Finding } \\
\text { information about } \\
\text { starting a business } \\
\text { and giving } \\
\text { information to } \\
\text { others is quite } \\
\text { difficult. }\end{array}$} & 9 & 35 & 83 & 19 & 8 & & \\
\hline & & $5.8 \%$ & $22.7 \%$ & $53.9 \%$ & $12.3 \%$ & $5.2 \%$ & 2.88 & .885 \\
\hline \multirow[b]{2}{*}{ EN 3} & \multirow{2}{*}{$\begin{array}{l}\text { Finding partners } \\
\text { or recruitment of } \\
\text { human resources } \\
\text { are not challenged. }\end{array}$} & 3 & 27 & 97 & 22 & 5 & \multirow[b]{2}{*}{2.99} & \multirow[b]{2}{*}{.728} \\
\hline & & $1.9 \%$ & $17.5 \%$ & $63.0 \%$ & $14.3 \%$ & $3.2 \%$ & & \\
\hline \multirow[b]{2}{*}{ EN 4} & \multirow[b]{2}{*}{$\begin{array}{l}\text { Entrepreneurial } \\
\text { policies and laws } \\
\text { associated with } \\
\text { entrepreneurship } \\
\text { have created many } \\
\text { favorable } \\
\text { conditions for } \\
\text { startups. }\end{array}$} & 3 & 26 & 62 & 52 & 11 & & \\
\hline & & $1.9 \%$ & $16.9 \%$ & $40.3 \%$ & $33.8 \%$ & $7.1 \%$ & 3.27 & .895 \\
\hline
\end{tabular}




\begin{tabular}{|c|l|c|c|c|c|c|c|c|}
\hline EN 5 & $\begin{array}{l}\text { Education } \\
\text { provides the } \\
\text { necessary } \\
\text { knowledge and } \\
\text { promotes skill } \\
\text { development for } \\
\text { students to } \\
\text { become } \\
\text { businesses. }\end{array}$ & $2.6 \%$ & $27.9 \%$ & $47.4 \%$ & $22.1 \%$ & $0 \%$ & 2.89 & .772 \\
\hline
\end{tabular}

In table $8,43.5 \%$ of respondents agree that their family and friends accept and support for their entrepreneurship. However, it was opposite with categories "Society has many support systems for entrepreneurial development", $43.5 \%$ of people disagree with this view. About $40 \%$ of respondents found many encouragement to entrepreneurship in the multimedia. Most of them (66.3\%) also recognized that "Start-up" contests also have largely attracted attention.

Table 8: Description of respondents about the view of social-culture for entrepreneurship

\begin{tabular}{|c|c|c|c|c|c|c|c|c|}
\hline \multirow[b]{2}{*}{ Item } & \multirow[b]{2}{*}{ Content } & \multicolumn{5}{|c|}{ Frequencies } & \multirow[b]{2}{*}{ Mean } & \multirow{2}{*}{$\begin{array}{c}\text { Std. } \\
\text { Deviation }\end{array}$} \\
\hline & & $\begin{array}{l}\text { Strongly } \\
\text { disagree }\end{array}$ & Disagree & Neutral & Agree & $\begin{array}{l}\text { Strongly } \\
\text { agree }\end{array}$ & & \\
\hline \multirow[b]{2}{*}{$\mathrm{SC} 1$} & \multirow{2}{*}{$\begin{array}{l}\text { Family and friends } \\
\text { will support your } \\
\text { entrepreneurship. }\end{array}$} & 0 & 1 & 83 & 67 & 3 & \multirow[b]{2}{*}{3.47} & \multirow[b]{2}{*}{.550} \\
\hline & & $0 \%$ & $0.6 \%$ & $53.9 \%$ & $43.5 \%$ & $1.9 \%$ & & \\
\hline \multirow[b]{2}{*}{$\mathrm{SC} 2$} & \multirow{2}{*}{$\begin{array}{l}\text { Society has many } \\
\text { support systems } \\
\text { for entrepreneurial } \\
\text { development. }\end{array}$} & 0 & 67 & 57 & 30 & 0 & \multirow[b]{2}{*}{2.76} & \multirow[b]{2}{*}{.759} \\
\hline & & $0 \%$ & $43.5 \%$ & $37.0 \%$ & $19.5 \%$ & $0 \%$ & & \\
\hline \multirow[b]{2}{*}{$\mathrm{SC} 3$} & \multirow{2}{*}{$\begin{array}{l}\text { Multimedia } \\
\text { communication } \\
\text { provides many } \\
\text { promotion } \\
\text { possibilities for } \\
\text { entrepreneurs. }\end{array}$} & 0 & 9 & 82 & 60 & 3 & \multirow[b]{2}{*}{3.37} & \multirow[b]{2}{*}{.626} \\
\hline & & $0 \%$ & $5.8 \%$ & $53.2 \%$ & $39.0 \%$ & $1.9 \%$ & & \\
\hline \multirow[b]{2}{*}{$\mathrm{SC} 4$} & \multirow{2}{*}{$\begin{array}{l}\text { Entrepreneurship } \\
\text { is an ideal job and } \\
\text { receives a lot of } \\
\text { admiration. }\end{array}$} & 9 & 12 & 88 & 37 & 8 & \multirow[b]{2}{*}{3.15} & \multirow[b]{2}{*}{.862} \\
\hline & & $5.8 \%$ & $7.8 \%$ & $57.1 \%$ & $24.0 \%$ & $5.2 \%$ & & \\
\hline \multirow[b]{2}{*}{ SC 5} & \multirow{2}{*}{$\begin{array}{l}\text { "Start-up" contests } \\
\text { has attracted much } \\
\text { public attention. }\end{array}$} & 0 & 0 & 52 & 68 & 34 & \multirow[b]{2}{*}{3.88} & \multirow[b]{2}{*}{.741} \\
\hline & & $0 \%$ & $0 \%$ & $33.8 \%$ & $44.2 \%$ & $22.1 \%$ & & \\
\hline
\end{tabular}

\subsection{Scale evaluation}

\section{Independent factor: Individual factor (IN)}

In this research the impact of individual factor (IN) on the spirit of entrepreneur, including the passion of an entrepreneur (IN 1), the ability to connect business with markets and customers (IN 
2), the knowledge and skills of entrepreneurs (IN 3), the sustainable value of entrepreneurial development (IN 4) and the experiences to become an entrepreneur (IN 5) are measured. Within the collected data, Cronbach's Alpha is 0.674 which is lower than 0.7 and Corrected Item-Total Correlation of IN 1, IN 2, IN 3, IN 4 and IN 5 are $0.456,0.521,0.624,0.273$ and 0.456 respectively. Besides, Cronbach's Alpha if item IN 4 deleted is 0.750. Therefore, when item IN 4 is rejected to the scale, the scale of individual factors achieves consistency and observed variables are considered to be reliable with four items: IN 1, IN 2, IN 3 and IN 5.

Table 9: Reliability analysis and Exploratory Factor Analysis of Individual factor

\begin{tabular}{|c|c|c|c|c|c|c|}
\hline \multicolumn{3}{|c|}{ Reliability analysis } & \multicolumn{4}{|c|}{ Validity analysis } \\
\hline $\begin{array}{c}\text { Observed } \\
\text { variable }\end{array}$ & $\begin{array}{c}\text { Corrected } \\
\text { Item-Total } \\
\text { Correlatio } \\
n\end{array}$ & $\begin{array}{l}\text { Cronbach' } \\
\text { s Alpha if } \\
\text { Item } \\
\text { Deleted }\end{array}$ & $\begin{array}{l}\text { Factor } \\
\text { loading }\end{array}$ & $\mathrm{KMO}$ & $\mathrm{p}$-value & TVE \% \\
\hline \multicolumn{7}{|c|}{ Cronbach's Alpha of IN: $\alpha=.674, N=5$} \\
\hline IN 1 & .456 & .628 & .699 & \multirow{5}{*}{.699} & \multirow{5}{*}{.000} & \multirow{5}{*}{$58.044 \%$} \\
\hline IN 2 & .521 & .599 & .788 & & & \\
\hline IN 3 & .624 & .522 & .789 & & & \\
\hline IN 4 & .273 & .750 & - & & & \\
\hline IN 5 & .456 & .613 & .768 & & & \\
\hline
\end{tabular}

Individual factor is the independent variable with four observed variables. The value of KMO of 0.699, which is approximate with 0.7 and the Bartlett's test significant that is lesser than 0.5 of this factor meets the requirements. Therefore, EFA analysis is also appropriate. With the principle component factor extraction method, using the Varimax perpendicular rotation, all observations load in one component and the scale have total variance explained is $58.044 \%$, larger than $50 \%$. The results show that the observed variables have a factor loading larger than the standard $(0.40)$ and the difference in factor loading of observations is higher than 0.3 , so none of the observed variables is deleted. That means, the individual factor can be used in this measurement scale.

\section{Independent factor: Environmental factor (EN)}

Additionally, the impact of environment on the spirit of entrepreneur, including the ability of accessing and maintaining the capital (EN1), the amount of available information (EN2), the human resources for working together (EN3), the support from the government (EN4) and entrepreneurial 
education (EN 5) are measured. Within the collected data, Cronbach's Alpha is 0.618 which is lower than 0.7 and Corrected Item-Total Correlation of EN 1, EN 2, EN 3, EN 4 and EN 5 are 0.486, 0.519, 0.584, 0.331 and 0.011 respectively. Because Corrected Item-Total Correlation of EN 5 is smaller than 0.3 and Cronbach's Alpha if Item EN 5 Deleted is 0.718 . Hence, the scale of environment just includes four items like EN 1, EN 2, EN 3 and EN 4 to be reliable.

Table 10: Reliability analysis and Exploratory Factor Analysis of Environmental factor

\begin{tabular}{|c|c|c|c|c|c|c|}
\hline \multicolumn{3}{|c|}{ Reliability analysis } & \multicolumn{4}{|c|}{ Validity analysis } \\
\hline $\begin{array}{c}\text { Observed } \\
\text { variable }\end{array}$ & $\begin{array}{c}\text { Corrected } \\
\text { Item-Total } \\
\text { Correlation }\end{array}$ & $\begin{array}{l}\text { Cronbach's } \\
\text { Alpha if } \\
\text { Item } \\
\text { Deleted }\end{array}$ & $\begin{array}{l}\text { Factor } \\
\text { loading }\end{array}$ & $\mathrm{KMO}$ & p-value & TVE \% \\
\hline \multicolumn{7}{|c|}{ Cronbach's Alpha of I: $\alpha=.757, \mathrm{~N}=4$} \\
\hline EN 1 & .486 & .501 & .785 & \multirow{5}{*}{.739} & \multirow{5}{*}{.000} & \multirow{5}{*}{$55.153 \%$} \\
\hline EN 2 & .519 & .479 & .749 & & & \\
\hline EN 3 & .581 & .468 & .801 & & & \\
\hline $\mathrm{EN} 4$ & .331 & .587 & .622 & & & \\
\hline EN 5 & .011 & .718 & - & & & \\
\hline
\end{tabular}

Environmental factor is the independent variable with four observed variables. The value of KMO of 0.739, which is higher than 0.7 and the Bartlett's test significant that is lesser than 0.5. These are the requirements to apply EFA. Therefore, EFA analysis is also appropriate. With the principle component factor extraction method, using the Varimax perpendicular rotation, all observations load in one component and the scale have total variance explained is $55.153 \%$, larger than $50 \%$. The results show that the observed variables have a factor loading larger than the standard $(0.40)$ and the difference in factor loading of observations is higher than 0.3 , so none of the observed variables is deleted. That means, the individual factor can be used in this measurement scale.

\section{Independent factor: Social - Cultural factor (SC)}

The final factor is social - cultural factor (SC) which is measured by using five questions, including the support from family, relatives and friends (SC 1), the support of the society for entrepreneurs (SC 2), the entrepreneurial promotion of multimedia communication (SC 3), people's views about becoming an entrepreneur themselves (SC 4) and the attention of society towards "Start-up" contests (SC 5). Within the collected data, Cronbach's Alpha is 0.683 which is smaller than 0.7 and 
Corrected Item-Total Correlation of SC 1, SC 2, SC 3, SC 4 and SC 5 are 0.685, 0.715, 0.590, -.540 and 0.625 respectively. The scale of social - cultural factor will delete item SC 4 since its corrected item-total correlation is lower than 0.3 . In short, the scale of social - cultural factor achieves consistency and observed variables are considered to be reliable with four items (SC 1, SC 2, SC 3 and SC 5) and it have new Cronbach's Alpha is 0.859.

Table 11: Reliability analysis and Exploratory Factor Analysis of Social - Cultural factor

\begin{tabular}{|c|c|c|c|c|c|c|}
\hline \multicolumn{3}{|c|}{ Reliability analysis } & \multicolumn{4}{|c|}{ Validity analysis } \\
\hline $\begin{array}{l}\text { Observed } \\
\text { variable }\end{array}$ & $\begin{array}{l}\text { Corrected } \\
\text { Item-Total } \\
\text { Correlation }\end{array}$ & $\begin{array}{l}\text { Cronbach's } \\
\text { Alpha if } \\
\text { Item } \\
\text { Deleted }\end{array}$ & $\begin{array}{l}\text { Factor } \\
\text { loading }\end{array}$ & $\mathrm{KMO}$ & p-value & TVE $\%$ \\
\hline \multicolumn{7}{|c|}{ Cronbach's Alpha of I: $\alpha=.758, \mathrm{~N}=5$} \\
\hline $\mathrm{SC} 1$ & .685 & .554 & .863 & \multirow{5}{*}{.717} & \multirow{5}{*}{.000} & \multirow{5}{*}{$71.181 \%$} \\
\hline $\mathrm{SC} 2$ & .715 & .492 & .918 & & & \\
\hline SC 3 & .6590 & .607 & .712 & & & \\
\hline $\mathrm{SC} 4$ & -.540 & .859 & - & & & \\
\hline $\mathrm{SC} 5$ & .625 & .542 & .868 & & & \\
\hline
\end{tabular}

Social - cultural factor is the independent variable with four observed variables. The value of KMO of 0.717, which is higher than 0.7 and the Bartlett's test significant that is lesser than 0.5 . These are the requirements to apply EFA. Therefore, EFA analysis is also appropriate. With the principle component factor extraction method, using the Varimax perpendicular rotation, all observations load in one component and the scale have total variance explained is $71.181 \%$, larger than $50 \%$. The results show that the observed variables have a factor loading larger than the standard $(0.40)$ and the difference in factor loading of observations is higher than 0.3 , so none of the observed variables is deleted. That means, the social - cultural factor can be used this measurement scale.

\section{Dependent variables: Entrepreneurship Development (BE)}

The variable entrepreneurial development $(\mathrm{BE})$ includes three items which encodes respectively BE1 - Target of life is to become an entrepreneur, BE 2 - Accepting the possible risks and BE 3 Ability of establishing a new business. Within the collected data, Cronbach's Alpha is 0.874 which is higher than 0.7 and Corrected Item-Total Correlation of BE 1, BE 2, BE 3, BE 4 and BE 5 are $0.682,0.736,0.653,0.652$ and 0.794 respectively which are higher than 0.3 . Therefore, the scale of 
entrepreneurship development achieves consistency and observed variables are considered to be reliable.

Table 12: Reliability analysis and Exploratory Factor Analysis of Entrepreneurship Development

\begin{tabular}{|c|c|c|c|c|c|c|}
\hline \multicolumn{3}{|c|}{ Reliability analysis } & \multicolumn{3}{|c|}{ Validity analysis } & \\
\hline $\begin{array}{c}\text { Observed } \\
\text { variable }\end{array}$ & $\begin{array}{l}\text { Corrected Item- } \\
\text { Total Correlation }\end{array}$ & $\begin{array}{c}\text { Cronbach's } \\
\text { Alpha if Item } \\
\text { Deleted }\end{array}$ & $\begin{array}{l}\text { Factor } \\
\text { loading }\end{array}$ & $\mathrm{KMO}$ & p-value & TVE \% \\
\hline \multicolumn{7}{|c|}{ Cronbach's Alpha of I: $\alpha=.874, \mathrm{~N}=5$} \\
\hline BE 1 & .682 & .853 & .805 & \multirow{5}{*}{.764} & \multirow{5}{*}{.000} & \multirow{5}{*}{$66.68 \%$} \\
\hline BE 2 & .736 & .840 & .847 & & & \\
\hline BE 3 & .653 & .860 & .772 & & & \\
\hline BE 4 & .652 & .860 & .772 & & & \\
\hline BE 5 & .794 & .825 & .882 & & & \\
\hline
\end{tabular}

Entrepreneurship development is the dependent variable with four observed variables. The value of $\mathrm{KMO}$ of 0.764 , which is higher than 0.7 and the Bartlett's test significant (p-value) is lesser than 0.5. These are the requirements to apply EFA. Therefore, EFA analysis is also appropriate. With the principle component factor extraction method, using the Varimax perpendicular rotation, all observations load in one component and the scale have total variance explained is $66.68 \%$, larger than $50 \%$. The results show that the observed variables have a factor loading larger than the standard (0.40) and the difference in factor loading of observations is higher than 0.3 , so none of the observed variables is deleted. That means, the entrepreneurship development can be used in this measurement scale.

In conclusion, item IN 4, EN 5 and SC 4 are rejected out the scale measured individual factors, environmental factors and social - cultural factors particularly. Another word, each dependent variable has four items to measure. While all items measured, entrepreneurship development is unchanged, keeping all five items.

\section{Exploratory factor analysis (EFA) for complete model}

After evaluation scale measurement, there are 17 observed variables which are significant. The model confirms one dependent variable and three independent variables. Therefore, exploratory factor analysis will apply separately for dependent and independent variables (Hair et al., 2010; 
Hair et al., 2015; Tho, 2012). Analysis result will present follow three categories: KMO index, Principals Component Analysis and Varimax rotation.

Table 13 shows that KMO index of dependent variable and independent variables are particularly .764 and .765 (>0.6), showing the suitability of the data for the analysis of main components (Pallant, 2011). Both Bartlett's value of two examined group is significant ( $p=0.000)$, less than 0.05 , indicates high importance. Thus, sampling indicates enough correlation between variables for further examination of complete model.

Table 13: KMO and Bartlett's Test

\begin{tabular}{|l|l|r|r|}
\hline \multicolumn{2}{|l|}{} & \multicolumn{1}{|c|}{$\begin{array}{c}\text { Dependent } \\
\text { variable }\end{array}$} & \multicolumn{1}{c|}{$\begin{array}{c}\text { Independent } \\
\text { variables }\end{array}$} \\
\hline Kaiser-Meyer-Olkin Measure of Sampling Adequacy & .764 & .765 \\
\hline \multirow{2}{*}{ Bartlett's Test of Sphericity } & Approx. Chi-Square & 461.913 & 804.457 \\
\cline { 2 - 4 } & df & 10 & .000 \\
\cline { 2 - 4 } & Sig. & .000 & .000 \\
\hline
\end{tabular}

From above result, the observed variables had the correlation with each other. That means EFA analysis has full requirements to conduct. In term of dependent variable, with extraction method is Principals Component Analysis, there is one component created by five observations. The total variance extracted of BE is $66.68 \%$. This $66.68 \%$ can clarify $66.68 \%$ of total variance explained. The results of Principals Component Analysis in independent variables show that the Eigenvalues value of all factors is high $(>1)$, the third factor has the lowest Eigenvalues is 1.393. It can be explained that with the Principal Component analysis, model allows 3 factors to be extracted from 12 observed variables and the total variance extracted (TVE\%) is $64.246 \%$, that means there are $64.246 \%$ variance can be explained in this examining.

Table 14 shows the result of varimax rotation matrix applied on dependent variable, divided observed variables into one component. All the observed variables have factors loading larger than the standard (0.5). Besides, there is no observed variables which have two factors loading in different component at the same time. Hence, none of the observed variable was rejected. From that, after factor analysis, observations of dependent variable are remained, without being added or reduced new variable. 
Table 14: Rotated Component Matrix ${ }^{a}$ of dependent variable

\begin{tabular}{|c|c|}
\hline \multirow{2}{*}{} & Component \\
\cline { 2 - 3 } & 1 \\
\hline BE 5 & .882 \\
\hline BE 2 & .874 \\
\hline BE 1 3 & .805 \\
\hline BE 4 & .772 \\
\hline $\begin{array}{l}\text { Extraction Method: Principal Component Analysis. } \\
\text { a. 1 components extracted. }\end{array}$ \\
\hline
\end{tabular}

Table 15 below shows the result of Exploratory Factor Analysis after applying principle components analysis, Varimax rotation, and cut off Eigenvalue of equal to above $1(>=1)$. Three components are established from 12 observations. Loading factors of each observations is higher than the standard. In addition, there is no disturbance of observed variables, meaning that statement sentences for each variable cannot be confused with another. In short, Varimax rotation with Kaiser Normalization in independent variables presents no new variable is created and both three independent variables kept the same the number of observations.

Table 15: Rotated Component Matrix ${ }^{a}$ of independent variable

\begin{tabular}{|c|r|r|l|}
\hline \multirow{2}{*}{} & \multicolumn{3}{|c|}{ Component } \\
\cline { 2 - 4 } & 1 & 2 & 3 \\
\hline SC 1 & .876 & & \\
\hline SC 2 & .844 & & \\
\hline SC 5 & .785 & & \\
\hline SC 3 & .757 & & \\
\hline EN 1 & & .799 & \\
\hline EN 3 & & .737 & \\
\hline EN 2 & & .699 & \\
\hline EN 4 & & .547 & \\
\hline
\end{tabular}




\begin{tabular}{|c|r|r|r|}
\hline IN 3 & & & .842 \\
\hline IN 5 & & & .791 \\
\hline IN 2 & & .681 \\
\hline IN 1 & & .609 \\
\hline $\begin{array}{l}\text { Extraction Method: Principal Component Analysis. } \\
\text { Rotation Method: Varimax with Kaiser Normalization. } \\
\text { a. Rotation converged in 4 iterations. }\end{array}$ \\
\hline
\end{tabular}

\subsection{Correlation analysis}

Correlation analysis is used to examine the linear relationship between variables, including between each independent variable and the dependent variable and among the independent variables. Table 16 shows the correlations between four variables.

Table 16: Correlations between variables

\begin{tabular}{|c|c|c|c|c|c|}
\hline & & BE & IN & EN & SC \\
\hline \multirow{3}{*}{ BE } & Pearson Correlation & 1 & $.514^{* *}$ & $.459^{* *}$ & $.320 * *$ \\
\hline & Sig. (2-tailed) & & .000 & .000 & .000 \\
\hline & $\mathrm{N}$ & 154 & 154 & 154 & 154 \\
\hline \multirow{3}{*}{ IN } & Pearson Correlation & & 1 & $.389^{* *}$ & $.183^{*}$ \\
\hline & Sig. (2-tailed) & & & .000 & .023 \\
\hline & $\mathrm{N}$ & & 154 & 154 & 154 \\
\hline \multirow{3}{*}{$\mathbf{E N}$} & Pearson Correlation & & & 1 & $.401^{* *}$ \\
\hline & Sig. (2-tailed) & & & & .000 \\
\hline & $\mathrm{N}$ & & & 154 & 154 \\
\hline \multirow{3}{*}{ SC } & Pearson Correlation & & & & 1 \\
\hline & Sig. (2-tailed) & & & & \\
\hline & $\mathrm{N}$ & & & & 154 \\
\hline
\end{tabular}


There are four variables, so six pair variables is examined. The result in table 16 shows sig. index of both 6 groups checked is significant, lower than 0.05 . It reflects the fact that each pair has linear correlation.

In detail, between dependent variable (entrepreneurship development) and three dependent variables (individual factors, environmental factors and social - cultural factors), the result is presented in the first gray line. Because the value of sig. is smaller than 0.05 , that means both three variables have linear correlation with entrepreneurship development variable. Besides, this result also correct with $\alpha=0.01$, that means the level of linear correlation between entrepreneurship development and three variables is high, with a confidence level of $99 \%$. Pearson correlation coefficient (r) of BE and IN, EN and SC is .514, .459, .320 particularly. Therefore, BE and IN have a strong correlation, while relationship between $\mathrm{BE}$ and $\mathrm{EN}$, as well as $\mathrm{BE}$ and $\mathrm{SC}$ is moderate. When $r$ equal or higher than 0.5 that is a strong relationship, the moderate correlation have value of $\mathrm{r}$ from 0.3 to 0.49 . All three index is in the area from 0 to 1 . Hence, BE have positive correlation with IN, EN and SC. It can be concluded that when individual factors, environmental factors and social - cultural factors have the good comments, entrepreneurship development would be more increasing.

When examining the relationship between among variables, including between IN and EN; IN and $\mathrm{SC}$; EN and SC. The result in table 16 shows the existence of linear relations in all three pairs, with the sig. is $.000, .023$ and .000 particularly, smaller than 0.05 . In detail, Pearson correlation coefficient of between IN and EN is 0.389 and correlation coefficient between EN and SC is 0.401 , belongs to the medium correlation. While Pearson correlation coefficient between IN and SC is 0.183 , it shows the weak correlation (lower or equal with 0.29 ). The relationship of three pair independent variables is a positive relation.

\subsection{Regression analysis}

In this section, the author uses multiple regression analysis to examine the hypotheses relationships through fitting a linear equation to observed data, from that attempts to point out the model for variables. Entrepreneurship development is considered to be an explanatory variable, and the others like individual factors, environmental factors and social - cultural factors are considered to be dependent variables. The coefficient value found indicated the cause and effect relationship between independent and dependent variables.

Based on Table 17, all independent variables are positively correlated with BE. In particular, the highest correlation is between $\mathrm{IN}$ and $\mathrm{BE}(\mathrm{B}=0.552$, sig. $=0.00<0.05)$, showing the close 
relationship between entrepreneurship development and individual factors. Contrary to that, SC (B $=0.194$, sig. $=0.038<0.05)$ have a low correlation, which means that the social - cultural factors are little related.

Table 17: Effect Coefficients between Independent Variables and BE

\begin{tabular}{|c|c|c|c|c|c|c|c|}
\hline \multirow{3}{*}{$\begin{array}{l}\text { Independent } \\
\text { variable }\end{array}$} & \multicolumn{7}{|c|}{ Dependent Variable (Y - Entrepreneurship development) } \\
\hline & \multicolumn{2}{|c|}{$\begin{array}{c}\text { Unstandardized } \\
\text { Coefficients }\end{array}$} & \multirow{2}{*}{$\begin{array}{c}\begin{array}{c}\text { Standardized } \\
\text { Coefficients }\end{array} \\
\text { Beta }\end{array}$} & \multirow{2}{*}{$\mathrm{T}$} & \multirow{2}{*}{ Sig. } & \multicolumn{2}{|c|}{$\begin{array}{l}\text { Collinearity } \\
\text { Statistics }\end{array}$} \\
\hline & B & Std. Error & & & & Tolerance & VIF \\
\hline (Constant) & 4.137 & 1.545 & & 2.678 & .008 & & \\
\hline $\begin{array}{l}X_{1} \text { - Individual } \\
\text { factors }\end{array}$ & .552 & .100 & .391 & 5.521 & .000 & .848 & 1.180 \\
\hline $\begin{array}{c}\mathrm{X}_{2}- \\
\text { Environmental } \\
\text { factors }\end{array}$ & .292 & .090 & .247 & 3.250 & .001 & .736 & 1.358 \\
\hline $\begin{array}{c}\mathrm{X}_{3}-\text { Social - } \\
\text { Cultural factors }\end{array}$ & .194 & .093 & .149 & 2.094 & .038 & .839 & 1.192 \\
\hline
\end{tabular}

The individual factors are significantly correlated with the entrepreneurship development as shown in the above table. The sig. of individual factors is .000 which is lower than 0.05 , having a significant impact on dependent variable. It means that with the significant level of $5 \%$, this factor has a significant impact on entrepreneurship development. In details, if IN increases or decreases one unit, BE will increase or decrease 0.552 units while EN and SC are constant.

Similarly, both environmental factors and social - cultural factors have significantly correlation with the entrepreneurship development. The sig. of environmental factors is .001 and sig. of socialcultural factors is .038 , both are smaller than 0.05 . Besides, B of EN is .292 , that means when EN increase or decrease one unit, BE will increase or decrease .292 units with IN and SC remains unchanged. It is similarly explained for B of SC, which value reach .194.

Standardized regression coefficients Beta reflects the influence of independent variable on dependent variable. Beta of IN is .391 and is highest in three value, so IN have the strongest effect on changing of entrepreneurship development. The independent variable has the second strongest impact on the dependent variable is EN, with beta being .247. The least influence on entrepreneurship development is SC with beta being .149 
Table 18: Model summary and ANOVA

\begin{tabular}{|l|r|r|r|r|r|}
\hline \multicolumn{1}{|c|}{ Model summary } & $\mathrm{r}=0.602$ & $\mathrm{R}^{2}=0.362$ & Adjusted $\mathrm{R}^{2}=0.349$ & \multicolumn{2}{|c|}{ Durbin Watson $=1.829$} \\
\hline Regression & $\begin{array}{c}\text { Sum of } \\
\text { Squares }\end{array}$ & \multicolumn{1}{|c|}{$\mathrm{df}$} & Mean Square & $\mathrm{F}$ & Sig. \\
\hline Residual & 478.223 & 3 & 159.408 & 28.389 & .000 \\
\hline Total & 1320.500 & 150 & 5.615 & & \\
\hline
\end{tabular}

As shown in table 18 above, there is the robust relationship between the observed and predicted value of dependent variable (entrepreneurship development) since the high value of multiple correlation coefficients $(\mathrm{R}=0.602)$. In addition, Adjusted $\mathrm{R}^{2}=0.349$ meant that $34.9 \%$ of the variance in entrepreneurship development can be predicted from three above factors (Individual factors, Environment factor and Social - cultural factors). Also, the ANOVA analysis in table 18 presented a significant model at the $95 \%$ confidence level ( $\operatorname{sig}$. of $\mathrm{F}=.000$, less than 0.05 ), with $\mathrm{F}=$ 28.389. Therefore, the linear regression model can be extrapolated and applicable to the population. The regression equation for $\mathrm{BE}$ is shown as below:

$$
\mathrm{BE}=4.137+.552 * \mathrm{IN}+.292 * \mathrm{EN}+.194 * \mathrm{SC}
$$

With: BE - Entrepreneurship Development

IN - Individual factors

EN - Environmental factors

$\mathrm{SC}-$ Social - cultural factors

\subsection{Multicollinearity and autocorrelation analysis}

In the correlation analysis, it is evident that three independent variables have relationship with together. Therefore, it is necessary to examine multicollinearity and autocorrelation phenomenon. In the regression model, multicollinearity phenomena are independent variables in the model that are interdependent and expressed as a function (Polonsky \& Waller, 2015). This will lead to standard errors of coefficients to be large, the confidence intervals to be large, statistics " $t$ " to be not significant and the estimates to be not very accurate. From that, the result of quantitative analysis does not make sense because rejecting the "no" hypothesis may not be true. In table 17, the value of variance inflation factor (VIF) of each variables are examined. In detail, VIF of IN, EN and SC are $1.180,1.358$, and 1.192 particularly. Both of values are lower than 2 , then model does not have 
multicollinearity. Notes: in normal, if VIF is smaller than 10, the model would be have multicollinearity. However, in studies about economy - society and using liker scale, assessment mark is commonly 2 .

In term of autocorrelation analysis, thesis compares Durbin - Watson of model with the Durbin Watson in statistics. With three independent variables and level of significance is $5 \%$, scanning on Durbin - Watson, dL and dU are 1.69 and 1.77 respectively (the number of samples is 154 answers) (Durbin \& Watson, 1971). In table 18, the value of Durbin Watson of model is 1.829 , belongs to zone of no autocorrelation when put the value on Durbin Watson's testing rule $(\mathrm{dU}=1.77<\mathrm{d}$ model $=1.829<4-\mathrm{dL}=2.23)$

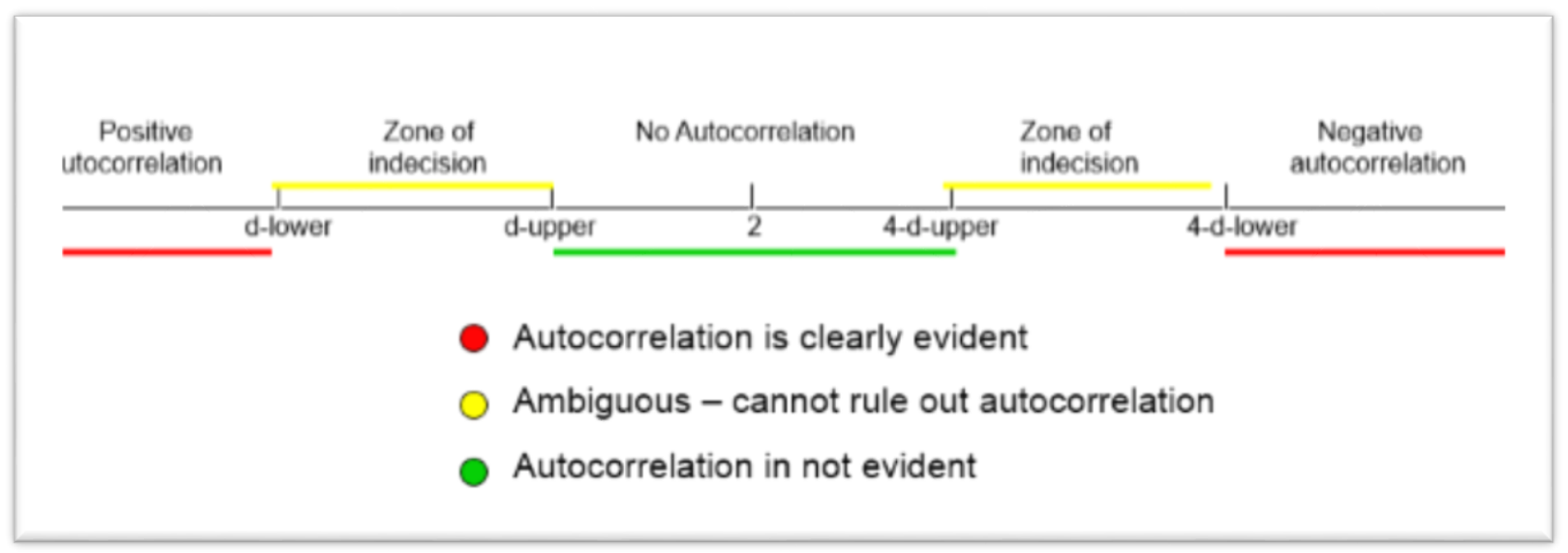

Figure 14: Durbin Watson's testing rule

Source: Durbin \& Watson (1971)

In conclusion, the model does not have multicollinearity and autocorrelation. That means that the model on the influence of individual factors, environmental factors and social - cultural factors on entrepreneurship development makes sense. Figure 15 summarizes the research results as follows.

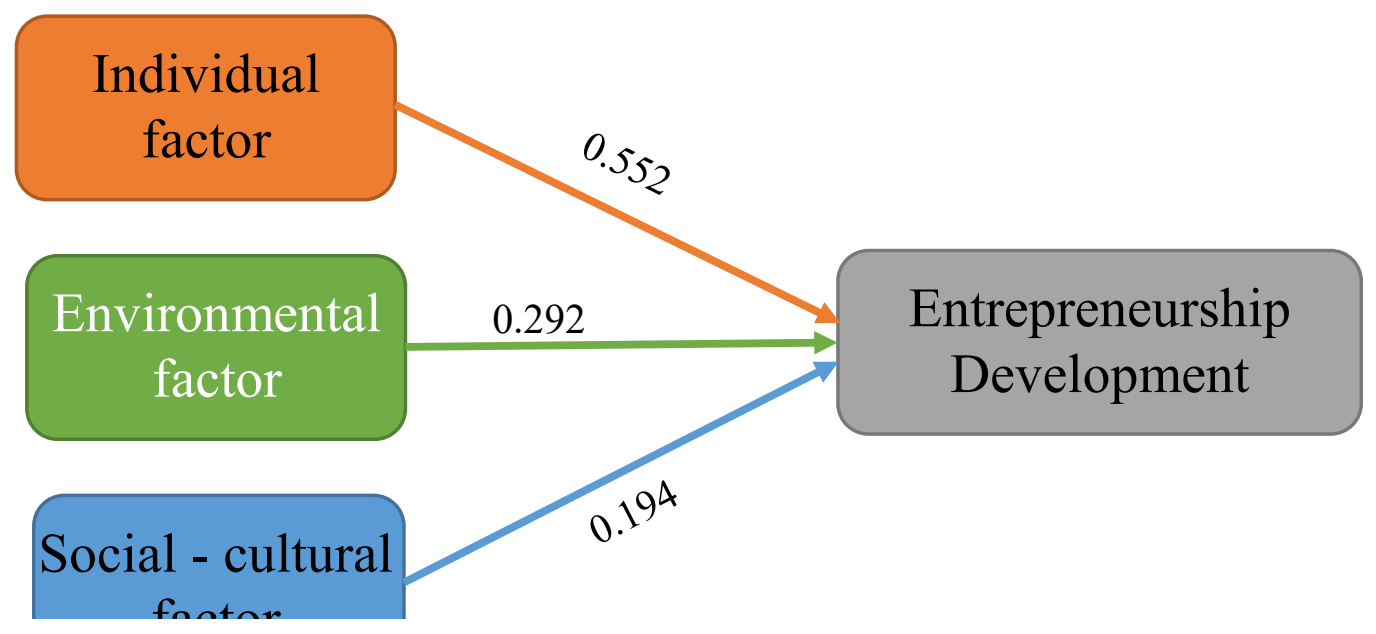

Figure 15: Path coefficients of hypothesis testing 


\section{Conclusions and Recommendations}

In this section the findings on the effects of individual factors, environmental factors and social cultural factors to entrepreneurship development are discussed. These results are also compared to previous studies and explained what they could mean in practice. This step is important because it will show whether this research is really meaningful and contribute to the field of entrepreneurship. In addition, the author makes a number of recommendations to improve entrepreneurial system in Ho Chi Minh City, Vietnam. Furthermore, this section also shows the limitations, debate some implementation and recommendations to do the further research on this topic.

\subsection{Discussion}

The thesis supplements to the general understanding of the connections between entrepreneurship development and individual, environmental and social - cultural factors. Overall, participants, as a sample of the Vietnamese youth, showed a medium level of desire to become the entrepreneurs. Statistics about the respondents' entrepreneurial ability are focused at value "Neutral", with the mean value from 3.44 to 3.58. This result can be explained by the reason to become entrepreneurs of Vietnamese. There are $35.07 \%$ of participants connected entrepreneurship with the possibility of improving their finance. In addition, $33.12 \%$ respondents chose all three options for reason becoming entrepreneurs. In the other words, improving finance is also one of targets of $33.12 \%$ respondents. To sum up, the main goal of Vietnamese entrepreneurs is improving finance. To get this target, most of Vietnamese entrepreneurs tend to imitate existing business models and did not focus on innovation (Ha et al., 2015). According to report of VCCI, the quality of Vietnamese entrepreneurs is low and the creativity index of entrepreneurship is also not high ("Global Entrepreneurship Monitor Report 2017-2018,” 2018). However, creativity and innovation is the core of entrepreneurship development (Drucker, 2014; Ko \& Butler, 2007; Loc, 2011). Therefore, the entrepreneurial index of Vietnam is not high.

Besides, the percentage of women who participated to the survey was higher than male. While the main reason for female in becoming entrepreneurs was enhancing finance, for the male it was exploiting opportunities. This result follows the results from the government report "Global Entrepreneurship Monitor Report 2017-2018 (2018). Furthermore, this finding can be explained by research of Tuan et al. (2019). It demonstrates that social - cultural differences have influenced the attitudes towards entrepreneurs of young people in developing countries. Comparing with developed countries, concern about income has reduced accepting the risk related to new venture creation (Iakovleva \& Kolvereid, 2011; Ozaralli \& Rivenburgh, 2016). Therefore, research results in the world do not apply completely in Vietnam. However, this result is different with 
identification of Tuan et al. (2019) which is not finding the linkage between social factors and the entrepreneurial intentions.

Nonetheless, the research cannot confirm that the entrepreneurial spirit of Vietnamese female is higher than male. Result of ANOVA does not examine the effect of gender on entrepreneurship development.

In relation with the original research hypotheses while analyzing data, the linear regression model is presented below. However, this model explains only $34.9 \%$ of the change in entrepreneurship. That means, only $34.9 \%$ variance in entrepreneurship development can be predicted from three factors, including Individual factors, Environment factor and Social - cultural factors.

- H1: Individual factors positively influence on entrepreneurship development;

- H2: Environmental factors positively influence on entrepreneurship development;

- H3: Social - Cultural factors positively influence on entrepreneurship development.

$$
\mathrm{BE}=4.137+.552 * \mathrm{IN}+.292 * \mathrm{EN}+.194 * \mathrm{SC}
$$

The above research results show that all independent variables including individual factors, environmental factors and social - cultural factors have a positive impact on entrepreneurship development. This means that when entrepreneurs are equipped with the necessary personal characteristics, business environment is improved and social - culture has enough support for entrepreneurs, the amount and quality of entrepreneurs would be enhance. This is completely consistent with previous studies (Gorji \& Rahimian, 2011; Ozaralli \& Rivenburgh, 2016; Sandhu et al., 2010).

Furthermore, this model can answer for the first sub - question. Throughout the findings, both three groups' factors, including: individual, environmental and social - cultural factors, have an influence on entrepreneurship development. In addition, the measurement scale is designed to estimate adorable level of factors. Thus, when the values show the positive relation between independent variables and dependent variable, it also presents the advantage of each factors in promoting entrepreneurship in Vietnam. However, as the efficiency of answers reaches to medium level (almost all focus on value "Neutral"), a small part of the factors are still considered as development barriers needed to be improved.

The results on table 17 can provide answers to the second sub - question. The research model shows that the individual factors variable has Beta $=0.391$, having the strongest impact on entrepreneurship development from the three variables. This can be explained as individual factors like knowledge, skills, experience and so on are the main barriers to prevent a person to continue 
with their business plan. Entrepreneurs need improve themselves before caring outside barriers. That is obvious because when entrepreneurs are doing well enough, they would have the ability to solve environmental as well as social - cultural problems. This is also the same with the intention stage. Tuan et al. (2019) also identified the importance of personality in the entrepreneurial intentions, in which desire for success and challenge, creativity and experience with entrepreneurship were significantly related to the intentions. Regarding to Theory of Planning Behavior, in line with other prior studies, perceived behavioral control and attitude towards entrepreneurship were positively associated with the entrepreneurial intentions (Iakovleva \& Kolvereid, 2011; Loan et al., 2018; Ozaralli \& Rivenburgh, 2016).

Analysis also points out the positive effect of environment to entrepreneurship development which has Beta $=0.292$. Research of Sandhu et al. (2010) and Turker \& Selcuk (2009) has the same observation that if environmental factors like institution, regulation, education and training supply enough resources for entrepreneurship, it would be encourage entrepreneurship in general. However, when a country does not have government assistance or other specialist advice to support in building future entrepreneurs, it would be a hurdle for the entrepreneur. Surprisingly, according the study of Turker \& Selcuk (2009), Quang \& Cuong (2017) and Loan et al. (2018) education could be seen an important factor in promoting entrepreneurship, however in this research, education and training program is a category which is rejected from the scale.

\subsection{Implications}

It is obvious that entrepreneurship has an important role for economy of country, especially with a developing country like Vietnam. Entrepreneurship is the motivation for economic growth. In Ho Chi Minh City - a dynamic city, government has many programs to promote entrepreneurship and complete entrepreneurial system. Therefore, finding entrepreneurs' needs and identifying barriers preventing entrepreneurship development is necessary.

First of all, the most important finding is a framework for understanding and analyzing the determinants of entrepreneurship. The thesis examined and pointed out the influence of individual, environmental and social - culture factors on entrepreneurship development. The model used in this thesis was designed and tested in practice. Besides, the thesis provides a systematic theoretical background of entrepreneurship, and also emphasizes the importance of innovative entrepreneurs to the economy and society. Thus, this study approach can be used for the research on entrepreneurship. 
Secondly, based on the analysis, individual factors are the strongest factors impacting on entrepreneurship development. Hence, this is also the huge barrier for development. The individual factors and entrepreneurship have the positive relation. Enhancing knowledge and skills of entrepreneurs could be improve entrepreneurship. In addition, entrepreneurial experience and passion should be promoted.

Thirdly, environmental factors also have a positive relationship with entrepreneurship development. The efficiency analysis showed that almost participants had good evaluation with statements described entrepreneurial environment, reach more $65 \%$ respondents. However, the small entrepreneurs were not satisfied with the environmental conditions, and thus the government's support, suitable policies and regulation, especially about finance and capital should be improved. Fourthly, regarding the influence of social - cultural factors, the view and social role of entrepreneurs is enhancing, but the traditional view about a low social role of entrepreneurs and the desire for a stable and low-risk job remain barriers to entrepreneurship. Therefore, communication is indispensable. Surveys also shows the advantage of the multimedia and "Start-up" contests for popularizing entrepreneurship. Consequently, government should push up this solution.

The final implication relates to level of willingness in becoming an entrepreneur in Ho Chi Minh City. Throughout the measurement, entrepreneurship's level in Ho Chi Minh City just reaches medium level, only 5.8\% respondents strongly agree that they want to become entrepreneurs. Another index to measure entrepreneurship are also not highly accepted. Therefore, if the government wants to use creative tools - entrepreneurship as a driving force for the development of the city, there should be stronger incentives for enhancing entrepreneurial attitude, especially among the young generation.

In conclusion, three groups of factors are not only barriers for entrepreneurship development, they are also the opportunities to promote entrepreneurship and build an entrepreneurial system. Thesis was meaningful evidence to pursue Ho Chi Minh City government to conduct more comprehensive action programs, supporting entrepreneurs on many fronts, not only in improving the business environment.

\subsection{Recommendations}

As stated in the introduction, Ho Chi Minh City entrepreneurial policies are focusing on environmental factors: administrative procedures, preferential policies, access to capital, and so on. However, based on the research results, the most powerful factors affecting entrepreneurship are the individual factors. Compared to Israel - the entrepreneurial model country, Vietnamese 
entrepreneurs still lacks basic elements. An Israeli entrepreneur is a citizen with all characteristics of an army, a businessman and a farmer. They have a spirit of fighting to never give up, with a sensitive entrepreneurial mind and a diligence and hard work of farmers. Therefore, the author proposes some recommendations to promote entrepreneurship, focusing mainly on individual factors.

Firstly, the awareness about entrepreneurship tested in the thesis only reached on medium level. Therefore, the thesis proposes that raising positive attitude of people with entrepreneurial activities is necessary to build a "startup society" and entrepreneurial culture. In Vietnam, one of the cultural barriers is not accepting the new and fear of failure and risk. According to Robertson et al. (2003) and Sondari (2014), education plays an important role in changing the perception of individuals and providing skills for entrepreneurs. Research in Indonesia also argue that one of effective solution to improve entrepreneurship is education (TAMBUNAN, 2007). With modern education, learners will have enough knowledge and skills to find solutions to problems (such as opportunity for financial gain, job satisfaction, positive view of economic outlook and awareness of the economic climate). From there, the fear of failure will decrease and the positive attitude toward entrepreneurship will improve. Besides that, entrepreneurship education is also the first and arguably the most important step for enhance an innovative culture (Stevenson, 2000; Wilson, 2008). Therefore, the Vietnamese education needs a revolution.

Secondly, communication is an effective channel in positively entrepreneurial influencing on citizens. Through media such as television, newspapers (both paper and electronics) and social networks, entrepreneurs have received necessary support, including: the ability to advertise in diverse forms, ability to connect with investors and customers; knowledge to become an entrepreneur and motivation to become entrepreneurs. Communication has a great influence on all issues of society. Communication affects social awareness, from awareness affects social actions and citizen's behaviors. Because of communication activities, entrepreneurs can easily access the new supporting policies of government, as well as new products of entrepreneurs are brought closer to society, and contrarily society can become closer to Vietnamese entrepreneurial ecosystem. Currently, the Ho Chi Minh City government has many programs and policies to support the startup community. However, communication activities are not really popular. It is clear on statistical result, perception of respondents about entrepreneurial city's communication is just on the medium level. Therefore, it is necessary to improve the quality of communication activities to create entrepreneurial culture for individuals and citizens. 


\subsubsection{Suggestion to improve education}

First of all, the school system, especially colleges and universities, should play a supporting role as a bridge in the entrepreneurial ecosystem. Thought out activities of schools, entrepreneurship culture could be brought to learners. The Australian Government has set up a foundation to promote education - encouraging training in the fields of science, technology, engineering and math to launch a culture of innovation among young people (Connor, 2013). The Malaysian government pioneered in the establishment of the National Entrepreneurship Institute (INSKEN) in 2005, with training for entrepreneurial programs for seniors in colleges and universities. At the end of the programs, students will receive a certificate and are eligible to apply for Graduate Entrepreneur Fund (Mohamed et al., 2012). In addition, without the general training program, schools can conduct extracurricular activities to stimulate students' interest in creative activities, in order to raise the awareness of innovation and explore creativity. Activities may include: organizing scientific research, modeling contests, idea and solutions contests, entrepreneurial playgrounds, entrepreneurial seminars, and actively connecting with entrepreneurial supported organizations. So that ideas and projects in the competition can developed in practice. This is the first step to forming entrepreneurship, an important personal trait of entrepreneurs. Entrepreneurial education should begin at high school level. It is clear that personal recognition and entrepreneurial skills and knowledge need to be developed over a long period (many years, not just in university period). The result of studying will be not work immediately.

Secondly, school system is a nuclear in building the capacity and knowledge for entrepreneurs. The school system, especially colleges and universities, is an effective and efficient academic environment for people. The training needs to be more practical. Currently, learning and testing knowledge in Vietnam only stops at the theoretical content. Therefore, a lot of practical content should be introduced, guiding students to apply their knowledge to work. For example, some universities in Singapore, students can choose to do a dissertation for graduation or an entrepreneurial project. Thus, university will be the first test in the entrepreneurial process. In addition, training also needs to emphasize the importance of competence and knowledge for entrepreneurs. It is obvious that the foundational knowledge and management skills are the core of a potential entrepreneurial project. The fact proves that, when entrepreneurs have good ideas and implementation plans, the problem of resources will be solved. Angel investors or venture capital funds only invest in effective potential plans.

Thirdly, the entrepreneurial training course should become a compulsory learning. Basic knowledge, practical knowledge and entrepreneurial experience should be the content of this 
course. Teaching not only provides the importance and benefits of entrepreneurship for learners, but also emphasizes the risks that can be encountered when starting a business. Figures from the Vietnam Chamber of Commerce and Industry (VCCI) showed that Vietnam is on the list of 20\% of countries with the most enthusiastic entrepreneurial spirit, but also in the group of $20 \%$ of enterprises with the lowest entrepreneurial quality in the world ("Global Entrepreneurship Monitor Report 2017-2018",2018). It proves that Vietnamese entrepreneurial wave is following too much the number of entrepreneurs and lacks in the quality. Entrepreneurial training should be offered in all majors, not just in economics and technology. In Sri Lanka, most universities have entrepreneurial courses and programs (Kumara, 2012). A number of studies have concluded that completing entrepreneurial training program at the university (whether under elective or compulsory courses), also have an effect on confidence improvement for students in career options. Both studies of Oosterbeek et al. (2010) and Souitaris et al. (2007) show that entrepreneurial courses increase the level of personal confidence and entrepreneurial awareness.

Fourthly, the connection between three actors in the startup ecosystem: government - schools entrepreneurships is necessary. An undeniable situation in Vietnam is that many of the research results after being accepted are not applied to production or commercialized in the market. The reason is the lack of connection between scientists and businesses. Therefore, encouraging cooperation and strengthening links between universities and entrepreneurships will create opportunities for both researchers and students to access technological needs and society needs. Since then, the research as well as potential entrepreneurial projects have been enhanced to apply in practice. In addition, cultural research should serve the need of community and society. In the other words, research should be a solution for market's issue or social problems. The typical lesson of the French Government is the reduction of taxes or the transfer of corporate taxes into contributions to universities and research institutes, to enhance this cooperation between entrepreneurship and school system. Moreover, government of Ho Chi Minh City can collect and provide data on important social issues and assign researchers and entrepreneurs to find solutions, implement programs, and develop resource plans (Sesen, 2012).

Fifth, during Industrial Revolution 4.0, the creative economy was created by the convergence of research and development $(\mathrm{R} \& \mathrm{D})$. Colleges and universities do not have only mission to transfer knowledge, but also develop talented nurseries. This is a clue to link with other components of the entrepreneurial ecosystem, both exploiting resources and supporting entrepreneurial activities. The incubator is a place to provide conditions for entrepreneurs to conduct research and develop products, for example: supporting infrastructure, connecting with invested funds, networking, and 
access to resources for entrepreneurial activities. From that, entrepreneurial projects have the opportunity to experiment with the real business environment. In addition, it is also important to set up entrepreneurial clubs to inspire students about entrepreneurship. Entrepreneurial clubs are a prerequisite for directing students to a method of self-study and practical learning by working; apply students' creativity and inventions to entrepreneurial practices.

\subsubsection{Suggestions for improving multimedia}

Communication needs to provide up-to-date and fast entrepreneurial information. Information is an advantage for entrepreneurs to profit resources. Therefore, government needs to complete the city's electronic entrepreneurial portal. The main content is providing information on technology, invention, measurement standards, quality standards, intellectual property, legal, regulations, policies and incentives. This is a reliable and cost-saving information source that entrepreneurs should benefit from. Besides, information portal also creates a forum to connect human resources and investment resources; introduce new products, services, business models; providing news, domestic and international events and other start-up activities. Through this information, entrepreneurs have more references to find solutions for their entrepreneurial problems facing. The role of the media is to engage with entrepreneurial communities, act as a component of the entrepreneurial ecosystem such as mentors, investors, customers ...; attract the attention, participation and investment of society including foreign countries. At a seminar about the role of Vietnamese media in entrepreneurship, an entrepreneur commented that media plays a very important role in supporting product promotion, attracting investors to entrepreneurial businesses. Through communication such as television, electronic newspapers, entrepreneurs have received a lot of investment capital. Besides, communication is also a means to bring products to the public. In fact, many startups have good products but have not taken any competitions, so their product has not become popular. Therefore, entrepreneurs desperately need media agencies to bring their products to the public, thereby attracting investors. Communication activities can promote entrepreneurships, such as: technological news, entrepreneurial stories, daily news about entrepreneurial seminars and associations, markets, exhibitions, events like Festival, Demo Day, Talk Shows and so on. Bringing the image of successful entrepreneur to the public will also boost strongly the entrepreneurial spirit in society.

Communication is a network providing entrepreneurial knowledge, with contents such as guidance and professional training which is a mentor for young people who are looking to becoming an entrepreneur, helping them to basically build a feasible project. However, in Vietnam, entrepreneurship is one of the "hottest trends" among young people. Following this wave training 
centers are providing enrichment skills, entrepreneurial skill training to become successful entrepreneurs. Entrepreneurial courses were established continuously without examining quality. For effective enrollment, courses often advertise about their start-up funds with great investment promise, but the fact is not the dream. Many people has taken part in these type of trainings and result was not same as their expected. It is one of the reasons causing negative perception of citizens about entrepreneurship. Therefore, the media should alert entrepreneurs, providing honest information. In addition, the verification of information should be taken seriously. This also contributes to the stabilizing social security, preventing and defeating the negative side of the "entrepreneurial movement" in promoting entrepreneurial process.

\subsection{Limitations and next research direction}

Due to time constraints and research funding, research results have their limitations. Firstly, about the sample size, the number of samples is not large enough (there are only 154 samples that can be used for data analyzing) and is not representative for the whole group of entrepreneurs in Ho Chi Minh City. In 2019, approximately 38,000 business would be established. A larger sample including various other respondents would make this investigation more global and generalizable. Besides, the thesis cannot examine a difference about entrepreneurship's level of respondents between groups of age, gender or education's level. The reason of this situation is a lack of normal distribution between the compared demographic groups.

Another important limitation of this study is the number of factors that are investigated. There are literally hundreds of variables that can influence entrepreneurship. Besides, some factors in the model were broadly defined and so broadly measured in the survey. For instance, individual factors could have been divided into two groups: personal traits and individual characteristics. The main reason of such broadness is to increase the generalizability of the model and make it available for the use of new studies in different contexts. However, some important factors could be rejected, and the explained value of model is not high enough. In many previous studies, education and training is determined as an important factor impacting on entrepreneurship development, but in this thesis, the statement sentence of this item was rejected during the analysis.

Next is the bias naturally happening in the progress of the study. During doing this research, the objectives of the study are to find, understand, interpret and examine the findings subjectively. Almost data were collected from the online survey; thus, it is difficult to control the quality of answers among respondents. 
Finally, data collected are based on the perceptions of the participants at a time. The research cannot verify the entrepreneurship of respondents after research. Therefore, statement sentences to measure entrepreneurship development is considered as an unreliable information.

From the some above limitations, the following orientations are proposed for the future research:

- The sample size should increase to a larger amount and the subjects could be with more diversity. It can make the model more generalizable and continuously examine the entrepreneurship's level in difference demographic groups. The increased sample size can make distribution value of difference demographic groups to be approximate normal distribution.

- Research can divide influent group factors to smaller factors. The addition of a new group factor can make clear what part of individual factors is a barrier for entrepreneurship development.

- Future research can design the new scale to examine the effect of entrepreneurial education and training program. In previous studies, this factors not only had impact on entrepreneurial intentions of students, but it also increased the motivation to become entrepreneurs as well as provided important knowledge and skill to establish a new venture.

- Thesis shows the relationship between three group's factors. Although, in this research, three group factors do not have multicollinearity. Many studies point out that environment and social cultural factors have impact on individual factors, especially to attitude and career desire (Zhang \& Yang, 2006). 


\section{References}

Abbate, T., \& Cesaroni, F. (2014). Market orientation and academic spin-off firms. Business Economics Working Papers, 1-26.

Abimbola, O. H., \& Agboola, M. G. (2011). Environmental factors and entrepreneurship development in Nigeria. Journal of Sustainable Development in Africa, 13(4), 166-176.

Ahmad, N., \& Hoffman, A. (2007). A Framework for Addressing and Measuring Entrepreneurship. (November).

Aidis, R., Estrin, S., \& Mickiewicz, T. (2008). Institutions and entrepreneurship development in Russia : A comparative perspective. Journal of Business Venturing, 23(June 2007), 656-672. https://doi.org/10.1016/j.jbusvent.2008.01.005

Amabile, T. M. (1997). Entrepreneurial Creativity Through Motivational Synergy. Journal of Creative Behavior, 31(1), 18-26. Retrieved from http://onlinelibrary.wiley.com/store/10.1002/j.2162-6057.1997.tb00778.x/asset/j.21626057.1997.tb00778.x.pdf? $v=1 \& \mathrm{t}=\mathrm{i} 1 \mathrm{i} 08 \mathrm{ykk} \& \mathrm{~s}=\mathrm{e} 2080998 \mathrm{~d} 36 \mathrm{a} 57 \mathrm{a} 9 \mathrm{a} 78051 \mathrm{fc} 20 \mathrm{e} 73 \mathrm{fd} 6 \mathrm{cf} 83795 \mathrm{c}$

Amit, R., Glosten, L., \& Muller, E. (1993). Challenges to theory development i n entrepreneurship research* raphael. Journal of Management Studies, (September), 815-834.

Anh, N. H., Giang, H. T., Tuan, D. V. H., \& Tram, H. B. (2016). A Review of Women 's Entrepreneurship in Vietnam Taking into Account Socio-Cultural Norms and the Institutional Ecosystem. SECO World Trade Institute, (11), 1-25.

Anh, Q. (2019). Ho Chi Minh City: A highlight in the country's entrepreneurial picture. Retrieved from Electronic Dicovery Magazine website: http://khampha.vn/khoa-hoc-cong-nghe/tphcmdiem-sang-trong-buc-tranh-khoi-nghiep-sang-tao-c7a739831.html

Antoncic, B., \& Hisrich, R. D. (2003). Clarifying the intrapreneurship concept. Journal of Small Business AndEnterprise Development, 10(1), 7-24. https://doi.org/10.1108/14626000310461187

Antoncic, B., Hisrich, R. D., \& Western, C. (2001). Intrapreneurship: Construct refinement and cross-cultural validation. Journal of Business Venturing, 16, 495-527.

Ardichvili, A., Cardozo, R., \& Ray, S. (2003). A theory of entrepreneurial opportunity identification and development. Journal of Business Venturing, 18(1), 105-123. https://doi.org/10.1016/j.jbusvent.2003.09.001 
Audretsch, D. B., \& Acs, Z. J. (1994). New-Firm Startups, Technology, and Macroeconomic Fluctuations. Small Business Economics, 6, 439-449.

Austrade. (2019). Vietnam's Innovation Ecosystem 2019 Report. Retrieved from https://www.austrade.gov.au/local-sites/vietnam/news/vietnam_innovation_ecosystem

Bailetti, T. (2012). Technology Entrepreneurship : Overview, Definition, and Distinctive Aspects. Technology Innovation Management Review, (February), 5-12.

Baumol, W. J. (2004). Entrepreneurial enterprises, large established firms and other components of the free-market growth machine. Small Business Economics, 23(1), 9-21.

Bhave, M. P. (1994). A Process model of Entrepreneurial venture creation. Journal of Business Venturing, 9, 223-242.

Bigliardi, B., Galati, F., \& Verbano, C. (2013). Evaluating Performance of University Spin-Off Companies : Lessons from Italy. Journal of Technology Management \& Innovation, 8(2), 178188.

Blank, S. (2010). What's A Startup? First Principles. Retrieved from https://steveblank.com/2010/01/25/whats-a-startup-first-principles/

Brandstätter, H. (2011). Personality aspects of entrepreneurship : A look at five meta-analyses. Personality and Individual Differences, 51, 222-230. https://doi.org/10.1016/j.paid.2010.07.007

Brünjes, J., \& Diez, J. R. (2012). Opportunity entrepreneurs - potential drivers of non-farm growth in rural Vietnam ? Marburg Geography, 1-28.

Bruton, G. D., Ketchen, D. J., \& Ireland, R. D. (2013). Entrepreneurship as a solution to poverty. Journal of Business Venturing, 28(6), 1-7. https://doi.org/10.1016/j.jbusvent.2013.05.002

Bruyat, C., \& Julien, P. A. (2001). Defining the field of research in entrepreneurship. Journal of Business Venturing, 16(2), 165-180. https://doi.org/10.1016/S0883-9026(99)00043-9

Bull, I., \& Willard, G. E. (1993). Towards a general theory of entrepreneurship. Journal of Business Venturing, 8(1), 183-195. https://doi.org/10.1186/1748-5908-8-18

Bygrave, W. D., \& Hofer, C. W. (1992). Theorizing about Entrepreneurship. Entrepreneurship Theory and Practice, 16(2), 13-22.

Carland, J. W., Hoy, F., \& Carland, J. A. C. (1988). “Who is an Entrepreneur ?” Is a Question Worth Asking. American Journal of Small Business, 12(4), 33-39. 
Carter, S., \& Wilton, W. (2006). “enterprise culture": necessary in promoting enterprise; lessons from enterprise development in zimbabwe steven carter. Journal of Enterprising Culture, 14(3), 177-198.

Castaño, M., Méndez, M., \& Galindo, M.-ángel. (2015). The effect of social, cultural, and economic factors on entrepreneurship. Journal of Business Research, 68(7).

Chand, M., \& Ghorbani, M. (2011). National culture, networks and ethnic entrepreneurship: A comparison of the Indian and Chinese immigrants in the US. International Business Review, 20, 593-606. https://doi.org/10.1016/J.IBUSREV.2011.02.009

Chieu, T. D. (2016). Towards the startup nation strategy. Finance Magazine, 6-9.

Chowdhury, M. S. (2007). Overcoming entrepreneurship development constraints : the case of Bangladesh. Journal of Enterprising Communities: People and Places in the Global Economy, 1(3), 240-251. https://doi.org/10.1108/17506200710779549

Covin, J. G., \& Slevin, D. P. (1991). A Conceptual Model of Entrepreneurship as Firm Behavior. Entrepreneurship Theory and Practice, 16(1), 7-26.

Creswell, J. W. (2014). Research design : qualitative, quantitative, and mixed methods approaches (4th ed.). United States of America Library: SAGE Publications, Inc.

Cronje, G. de J., Breebaart, H., Klerk, D. A., Old, S., \& Swanepoel, E. (2002). Chapter 3 : The entrepreneurship process. In Introduction to Entrepreneurship and Small Business Management (pp. 82-116). Pretoria University of South Africa.

Davidsson, P., Delmar, F., \& Wiklund, J. (2006). Entrepreneurship as Growth ; Entrepreneurship as Growth; Growth as Entrepreneurship. Entrepreneurship and the Growth of Firms, 1, 21-35.

Debroux, P. (2013). Female Entrepreneurship in Asia : The Case of Japan, South-Korea, Malaysia and Vietnam. 創価経営論集, 37(1), 1-23.

Dewett, T. (2007). Linking intrinsic motivation, risk taking, and employee creativity in an R\&D environment. $R$ and D Management, 37(3), 197-208. https://doi.org/10.1111/j.14679310.2007.00469.x

Douglas, E. J., \& Shepherd, D. A. (2002). Self-Employment as a Career Choice: Attitudes, Entrepreneurial Intentions, and Utility Maximization. Entrepreneurship Theory and Practice, 26(3), 81-90.

Driessen, M. P., \& Zwart, P. S. (2006). The Entrepreneur Scan Measuring Characteristics and Traits 
of Entrepreneurs. Maandblad Voor Accountancy En Bedrijfseconomie, (Juli/Aug), 382-391. Retrieved from https://entrepreneurscan.com//wp-content/uploads/2016/09/E-Scan-MABArticle-UK.pdf

Drucker, P. (2014). Innovation and entrepreneurship.

Durbin, J., \& Watson, G. . (1971). Testing for Serial correlation in Least Squares Regression. III. Biometrika, 58, 159-177. Retrieved from https://doi.org/10.1093/biomet/58.1.1

Entrepreneurs Portal. (2018). 15 years with the national entrepreneurs. Retrieved from https://khoinghiep.org.vn/index.php/15-nam-cung-dat-nuoc-khoi-nghiep-11421.html

Feld, B. (2012). Startup communities: Building an entrepreneurial ecosystem in your city. Retrieved from https://books.google.com.vn/books?hl=vi\&lr=\&id=tFNAYRBjsuIC\&oi=fnd\&pg=PT12\&ots=5 9rr-sNgDd\&sig=3SnBwBfCwkwoXW157H2XQ1Eac0g\&redir_esc=y\#v=onepage\&q\&f=false

Fishbein, M., \& Ajzen, I. (2011). Predicting and Changing Behavior: The Reasoned Action Approach. New York: Psychology Press, Taylor \& Francis Group.

Gartner, W. B. (1988). “Who Is an Entrepreneur?” Is the Wrong Question. American Journal of Small Business, 12(4), 11-32. https://doi.org/10.1177/104225878801200401

Global Entrepreneurship Monitor Report 2015. (2016). Vietnam Chamber of Commerce and Industry.

Global Entrepreneurship Monitor Report 2017-2018. (2018). Vietnam Chamber of Commerce and Industry.

Gorji, M. B., \& Rahimian, P. (2011). The study of barriers to entrepreneurship in men and women. Australian Journal of Business and Management Research, 1(9), 31-36.

Graevenitz, G. Von, Harho, D., \& Weber, R. (2010). The Effects of Entrepreneurship Education. Journal of Economic Behavior \& Organization, 76(1), 90-112.

Greve, A., \& Salaff, J. W. (2003). Social Networks and Entrepreneurship. Entrepreneurship Theory and Practice, 28(1), 1-22.

Grilo, I., \& Thurik, R. (2008). Determinants of entrepreneurial engagement levels in Europe and the US. Industrial and Corporate Change, 17(6), 1113-1145.

Gurel, E., Altinay, L., \& Daniele, R. (2010). Tourism students' entrepreneurial intentions. Annals of Tourism Research, 37(3), 646-669. https://doi.org/10.1016/j.annals.2009.12.003 
Ha, L. M., Hang, D. T., \& Trang, V. T. (2015). Vietnamese entrepreneurs: From trust to reality. Economy and Forecast Review.

Hair, J. F., Black, W. C., Babin, B. J., \& Anderson, R. E. (2010). Multivariate Data Analysis (7th Ed.) (Seventh Ed). United States of America: Pearson Education Limited.

Hair, J. F., Celsi, M., Money, A., Samouel, P., \& Page, M. (2015). Essentials of Business Research Methods (Third Edit). New York and London: Routledge.

Hammer, M., \& Champy, J. (2007). Reengineering the Corporation: A Manifesto for Business Revolution.

Hebert, R. F., \& Link, A. N. (1989). In Search of the Meaning of Entrepreneurship. Small Business Economics, 1, 39-49.

Hian, C. K. (1996). Testing hypotheses of entrepreneurial characteristics: A study of Hong Kong MBA students. Journal of Managerial Psychology, 11(3), 12-25.

Hindle, K. (2010). How community context affects entrepreneurial process : A diagnostic framework. Entrepreneurship \& Regional Development, 22(7-8), 599-647. https://doi.org/10.1080/08985626.2010.522057

Hoang, V. Q., \& Dung, T. T. (2009). The Cultural Dimensions of the Vietnamese Private Entrepreneurship. The IUP Journal of Entrepreneurship and Development, 6(3), 54-78.

Huefner, J., \& Flanagan, F. (1998). Not all small business owners are entrepreneurs. Academy of Entrepreneurship Journal, 4(2).

Huyen, M. (2019). Completing entrepreneurial ecosystem pieces. Retrieved from Saigon Times Online website: https://www.thesaigontimes.vn/290563/Hoan-thien-nhung-manh-ghep-hesinh-thai-khoi-nghiep.html

Huynh, D. (2019). Making Megacities in Asia Comparing National Economic Development Trajectories.

Iakovleva, T., \& Kolvereid, L. (2011). Entrepreneurial intentions in developing and developed countries. Education \& Training, 53(5), 353-370. https://doi.org/10.1108/00400911111147686

Infographic: Economic picture of Ho Chi Minh City in the first 6 months of 2019. (2019). Retrieved from Vietnam News Agency website: https://infographics.vn/thanh-pho-ho-chi-minh-giuvung-vi-tri-la-trung-tam-kinh-te-lon-nhat-ca-nuoc/13399.vna 
Iversen, J., Jørgensen, R., \& Malchow-møller, N. (2008). Defining and Measuring Entrepreneurship. Foundations and Trends ${ }^{\circledR}$ in Entrepreneurship, 4(1), 1-63. https://doi.org/10.1561/0300000020

Jafarnejad, A., Abbaszadeh, M. A., Ebrahimi, M., \& Abtahi, S. M. (2013). Analysis of barriers to entrepreneurship in Small and Medium-sized Enterprises ( SMEs ). International Journal of Academic Research in Economics and Management Sciences, 2(4), 207-216. https://doi.org/10.6007/IJAREMS/v2-i4/155

Jahanshahi, A. A., Nawaser, K., Khaksar, S. M. S., \& Kamalian, A. R. (2011). The Relationship between Government Policy and the Growth of Entrepreneurship in the Micro, Small \& Medium Enterprises of India. Journal of Technology Management \& Innovation, 6(1), 66-76.

Jon, J., \& Welsch, H. (2008). Patterns of venture gestation process : Exploring the differences between tech and non-tech nascent entrepreneurs. Journal of High Technology Management Research, 19(2), 103-113. https://doi.org/10.1016/j.hitech.2008.10.003

Kebaili, B., Al-Subyae, S. S., Al-Qahtani, F., \& Belkhamza, Z. (2015). An exploratory study of entrepreneurship barriers: the case of Qatar. World Journal of Entrepreneurship, Management and Sustainable Development, 11(3), 210-219.

Klapper, L., Laeven, L., \& Rajan, R. (2004). Barriers to Entrepreneurship. NBER Working Paper.

Ko, S., \& Butler, J. E. (2007). Creativity: A key link to entrepreneurial behavior. Business Horizons, 50(5), 365-372. https://doi.org/10.1016/j.bushor.2007.03.002

Kobia, M., \& Sikalieh, D. (2010). Towards a search for the meaning of entrepreneurship. Journal of European Industrial Training, 34(2), 110-127. https://doi.org/10.1108/03090591011023970

Kolvereid, L. (1996). Organizational employment versus self-employment: Reasons for career choice intentions. Entrepreneurship Theory and Practice, 20(3), 23-31.

Kornai, J. (1990). The road to a free economy. Shifting from a socialist system: the example of Hungary.

Korosec, R. L., \& Berman, E. M. (2006). Municipal support for social entrepreneurship. Public Administration Review, 66(3), 448-462. https://doi.org/10.1111/j.1540-6210.2006.00601.x

Kouriloff, M. (2000). Exploring Perceptions of A Priori Barriers to Entrepreneurship: A Multidisciplinary Approach. Entrepreneurship Theory and Practice, 25(2), 59-80.

Krueger, N. F., \& Brazeal, D. V. (1994). Entrepreneurial Potential and Potential Entrepreneurs. 
Entrepreneurship Theory and Practice, 18(3), 91-104.

Krueger, N. F., Reilly, M. D., \& Carsrud, A. L. (2000). Competing models of entrepreneurial intentions. Journal of Business Venturing, 15, 411-432.

Kukoc, K., \& Regan, D. (2008). Measuring entrepreneurship. Economic Round-Up, 15-26.

Kumara, P. A. P. S. (2012). Undergraduates ' intention towards entrepreneurship: empirical evidence from Sri Lanka. Journal of Enterprising Culture, 20(1), 105-118. https://doi.org/10.1142/S0218495812500057

Kuratko, D. F., Montagno, R. A. Y. V, \& Hornsby, J. S. (1990). Developing an intrapreneurial assessment instrument for an effective corporate entrepreneurial environment. Strategic Management Journal, 11, 49-58.

Le. (2019). Ho Chi Minh City maintains its position as the largest economic center in the country. Retrieved from Vietnam Communist Party electronic newspaper website: http://dangcongsan.vn/thoi-su/tp-ho-chi-minh-giu-vung-vi-tri-la-trung-tam-kinh-te-lon-nhatca-nuoc-527828.html

Learned, K. E. (1992). What Happened Before the Organization? A Model of Organization Formation. Entrepreneurship Theory and Practice, 17(1), 39-48.

Liñán, F. (2004). Intention-based models of entrepreneurship education. Piccolla Impresa/Small Business, 3(1), 11-35.

Liñán, F., \& Chen, Y. (2009). Development and cross-cultural application of a specific instrument to measure entrepreneurial intentions. Entrepreneurship Theory and Practice, 33(3), 593-617.

Loan, B. T. T., Ngan, N. T., \& Linh, N. T. (2018). Factors affecting the student's intention to start a business: A case study of students in Hanoi. Economics - Society, 46, 73-77.

Loc, N. V. (2011). Entrepreneurship - The basis for building the cultural value system of Vietnamese entrepreneurs. Economics and Business Magazine, 27, 232-239.

Lockyer, J., \& George, S. (2012). What women want : barriers to female entrepreneurship in the West Midlands. International Journal of Gender and Entrepreneurship, 4(5), 179-195. https://doi.org/10.1108/17566261211234661

Lüthje, C., \& Franke, N. (2003). The "making" of an entrepreneur: Testing a model of entrepreneurial intent among engineering students at MIT. $R$ and D Management, 33(2), 135147. https://doi.org/10.1111/1467-9310.00288 
Märijärvi, J., Hokkanen, L., Komssi, M., Kiljander, H., Xu, Y., \& Raatikainen, Mikko ... \& Järvinen, J. (2016). The cookbook for successful internal startups.

Marques, C. S. E., Ferreira, J. J. M., Ferreira, F. A. F., \& Lages, M. F. S. (2013). Entrepreneurial orientation and motivation to start up a business : evidence from the health service industry. International Entrepreneurship and Management Journal, 9(1), 77-94. https://doi.org/10.1007/s11365-012-0243-2

McClelland, D. C. (1986). Characteristics of successful entrepreneurs in Mexico. The Journal of Creative Behavior, 21(3), 1-7.

McKenzie, B., Ugbah, S. D., \& Smothers, N. (2007). “Who Is an Entrepreneur?” Is It Still the Wrong Question? Academy of Entrepreneurship Journal, 13(1), 23-43.

Mechanisms and policies on entrepreneurship ecosystem. (2019). Retrieved from Department of Planning and Investment of Ho Chi Minh City website: http://www.dpi.hochiminhcity.gov.vn/TinTuc/cthotrodnnhovavua/Pages/default.aspx

Michael, M., \& Phillipa, N. (2009). Policy Entrepreneurship and Policy Change. Policy Studies Journal, 37(4), 649-667. Retrieved from http://dx.doi.org/10.1111/j.1541-0072.2009.00329.x

Miner, J. B., \& Raju, N. S. (2004). Risk Propensity Differences Between Managers and Entrepreneurs and Between Low- and High-Growth Entrepreneurs : A Reply in a More Conservative Vein. Journal of Applied Psychology, 89(1), 3-13. https://doi.org/10.1037/00219010.89 .1 .3

Mohamed, Z., Rezai, G., Shamsudin, M. N., \& Mu, M. (2012). Enhancing young graduates ' intention towards entrepreneurship development in Malaysia. Education + Training, 54(7), 605-618. https://doi.org/10.1108/00400911211265648

Moica, S., Socaciu, T., \& Rădulescu, E. (2013). Model Innovation System for Economical Development using Entrepreneurship Education. Procedia Economics and Finance, 3(12), 521-526. https://doi.org/10.1016/s2212-5671(12)00190-6

Moroz, P. W., \& Hindle, K. (2012). Entrepreneurship as a Process : Toward Harmonizing Multiple Perspectives. Entrepreneurship Theory and Practice, 36(4), 781-818. https://doi.org/10.1111/j.1540-6520.2011.00452.x

Mutisya, P. (2011). Lectures for Entrepreneurship.

Nabi, G., \& Lin, F. (2011). Graduate entrepreneurship in the developing world : intentions , 
education and development. Education \& Training, 53(5), 325-334.

https://doi.org/10.1108/00400911111147668

Naser, K., Mohammed, W. R., \& Nuseibeh, R. (2009). Factors that affect women entrepreneurs: evidence from an emerging economy. International Journal of Organizational Analysis, 17(3), $225-247$.

O’Connor, A. (2013). A conceptual framework for entrepreneurship education policy: Meeting government and economic purposes. Journal of Business Venturing, 28(4), 546-563. https://doi.org/10.1016/j.jbusvent.2012.07.003

Oosterbeek, H., Praag, M. Van, \& Ijsselstein, A. (2010). The impact of entrepreneurship education on entrepreneurship skills. European Economic Review, 54(3), 442-454. https://doi.org/10.1016/j.euroecorev.2009.08.002

Ozaralli, N., \& Rivenburgh, N. K. (2016). Entrepreneurial intention : antecedents to entrepreneurial behavior in the U.S.A. and Turkey. Journal of Global Entrepreneurship Research, 6(1). https://doi.org/10.1186/s40497-016-0047-x

Pallant, J. (2011). Survival Manual A Step by Step Guide to Data Analysis using SPSS for Windows. Open University Press.

Parker, S. C. (2011). Journal of Business Venturing Intrapreneurship or entrepreneurship ? Journal of Business Venturing, 26(1), 19-34. https://doi.org/10.1016/j.jbusvent.2009.07.003

Peneder, M. (2009). The Meaning of Entrepreneurship : A Modular Concept. Journal of Industry: Competition and Trade, 9(2), 77-99. https://doi.org/10.1007/s10842-009-0052-7

Polonsky, M. J., \& Waller, D. S. (2015). Designing and Managing a Research Project (Third Edit). Los Angeles: SAGE Publications, Inc. All.

Pruett, M., Shinnar, R., Toney, B., Carolina, N., Llopis, F., \& Fox, J. (2008). Explaining entrepreneurial intentions of university students : a cross-cultural study. International Journal of Entrepreneurial Behaviour \& Research, 15(6), 571-594. https://doi.org/10.1108/13552550910995443

Quang, B. N. (2017). Vietnamese start-ups in the Fourth Industrial Revolution. Vietnam Academy of Social Sciences, 10, 35-43.

Quang, N. H., \& Cuong, C. N. T. (2017). Determinants to student's entrepreneurial intentions of aculty of business administration at University of Economics and Law. Science Magazine, 25, 
$10-19$.

Rasmussen, E., \& Gulbrandsen, M. (2012). Government Support Programmes to Promote Academic Entrepreneurship: A Principal-Agent Perspective. European Planning Studies, 20(4), 527-546. https://doi.org/10.1080/09654313.2012.665035

Rauch, A., \& Frese, M. (2007). Let' s put the person back into entrepreneurship research : A metaanalysis on the relationship between business owners ' personality traits , business creation , and success and success. European Journal of Work and Organizational Psychology, 16, 353 385. https://doi.org/10.1080/13594320701595438

Reynolds, P. D., Hay, M., Bygrave, W. D., Camp, S. M., \& Autio, E. (2000). Global entrepreneurship monitor: 2000 Executive Report.

Ribeiro-Soriano, D., \& Galindo-Martín, M. Á. (2012). Government policies to support entrepreneurship. Entrepreneurship and Regional Development, 24(9-10), 861-864. https://doi.org/10.1080/08985626.2012.742322

Robbins, S., Diego, U. D. S., Decenzo, D., Carolina, U. D. C., \& Gabilliet, A. P. (1994). Management, 4 e éd.

Robertson, M., Collins, A., Medeira, N., \& Slater, J. (2003). Education + Training Barriers to start up and their effect on aspirant entrepreneurs Barriers to start-up and their effect on aspirant entrepreneurs. Education + Training, 45(6), 308-316. https://doi.org/10.1108/00400910310495950

Robinson, P. B., Stimpson, D. V., Huefner, J. C., \& Hunt, H. K. (2018). An Attitude Approach to the Prediction of Entrepreneurship. Entrepreneurship Theory and Practice, 15(4), 13-32. https://doi.org/10.1177/104225879101500405

Samitowska, W. (2011). Barriers to the development of entrepreneurship demonstrated by micro, small and medium enterprises in Poland. Economics \& Sociology, 4(2), 42-49.

Sandhu, M. S., Sidique, S. F., \& Riaz, S. (2010). Entrepreneurship barriers and entrepreneurial inclination among Malaysian postgraduate students. International Journal of Entrepreneurial Behavior \& Research, 17(4), 428-449. https://doi.org/10.1108/13552551111139656

Schaper, M. (2010). Understanding the green entrepreneur. In Making Ecopreneurs: Developing Sustainable Entrepreneurship (pp. 7-20).

Sesen, H. (2012). Personality or environment? A comprehensive study on the entrepreneurial 
intentions of university students. Education + Training, 55(7), 624-640.

https://doi.org/10.1108/ET-05-2012-0059

Shane, S. (2003). A general theory of entrepreneurship: The individual-opportunity nexus. Edward Elgar.

Shane, S., \& Venkataraman, S. (2000). The promise of entrepreneurship as a field of research. Academy of Management Review, 25(1), 217-227.

Sharma, L., \& Madan, P. (2013). Affect of individual factors on youth entrepreneurship-A study of Uttarakhand state, India. Romanian Economic and Business Review, pp. 131-143.

Sondari, M. C. (2014). Is Entrepreneurship Education Really Needed ? : Examining the Antecedent of Entrepreneurial Career Intention. Procedia - Social and Behavioral Sciences, 115(Iicies 2013), 44-53. https://doi.org/10.1016/j.sbspro.2014.02.414

Souitaris, V., Zerbinati, S., \& Al-laham, A. (2007). Do entrepreneurship programmes raise entrepreneurial intention of science and engineering students? The effect of learning, inspiration and resources. Journal of Business Venturing, 22, 566-591.

https://doi.org/10.1016/j.jbusvent.2006.05.002

Stephen, F. H., Urbano, D., \& Hemmen, S. Van. (2005). The Impact of Institutions on Entrepreneurial Activity. Managerial and Decision Economics, 26(7), 413-419. https://doi.org/10.1002/mde.1254

Stevenson, H. H. (1983). A Perspective on Entrepreneurship. Harvard Business School Background Note, 13.

Stevenson, H. H. (2000). Why entrepreneurship has won! Coleman White Paper, 2(4), 1-21.

Stewart, W. H., \& Roth, P. L. (2001). Risk Propensity Differences Between Entrepreneurs and Managers : A Meta-Analytic Review. Journal of Applied Psychology, 86(1), 145-153. https://doi.org/10.1037//0021-9010.86.1.145

Stewart, W. H., \& Roth, P. L. (2004). Data Quality Affects Meta-Analytic Conclusions : A Response to Miner and Raju ( 2004 ) Concerning Entrepreneurial Risk Propensity. Journal of Applied Psychology, 89(1), 14-21. https://doi.org/10.1037/0021-9010.89.1.14

Stuart, T. E., \& Sorenson, O. (2005). Social networks and entrepreneurship. Handbook of Entrepreneurship Research, 233-252.

Suresh, J., \& Ramraj, R. (2012). Entrepreneurial Ecosystem : Case Study on the Influence of 
Environmental Factors on Entrepreneurial Success. European Journal of Business and Management, 4(16), 95-102.

Tabachnick, B. G., \& Fidell, L. S. (2006). Using Multivariate Statistics (5th Editio). United States: Allyn \& Bacon, Inc.

TAMBUNAN, T. (2007). Entrepreneurship Development: Smes in Indonesia. Journal of Developmental Entrepreneurship, 12(01), 95-118. https://doi.org/10.1142/s1084946707000575

Tavakol, M., \& Dennick, R. (2011). Making sense of Cronbach's alpha. International Journal of Medical Education, 2, 53-55. https://doi.org/10.5116/ijme.4dfb.8dfd

Tho, N. D. (2012). Research Method in Business. Ho Chi Minh City: Finance Publisher.

Thornton, P. H., Ribeiro-soriano, D., \& Urbano, D. (2011). Socio-cultural factors and entrepreneurial activity: An overview. International Small Business Journal, 29(2), 105-118. https://doi.org/10.1177/0266242610391930

Timmons, J. A., Spinelli, S., \& Tan, Y. (1994). New venture creation: Entrepreneurship for the 21st century (Vol. 4). Burr Ridge, IL: Irwin.

Tuan, N. A., Ha, D. T. H., Thao, V. T. B., Anh, D. K., \& Long, N. H. (2019). Factors Affecting Entrepreneurial Intentions among Youths in Vietnam. Children and Youth Services Review. https://doi.org/10.1016/j.childyouth.2019.01.039

Turker, D., \& Selcuk, S. S. (2009). Which factors affect entrepreneurial intention of university students? Journal of European Industrial Training, 33(2), 142-159. https://doi.org/10.1108/03090590910939049

Urbano, D., Toledano, N., \& Domingo, R. (2011). Socio-cultural factors and transnational entrepreneurship: A multiple case study in Spain. International Small Business Journal, 29(2), 119-134. https://doi.org/10.1177/0266242610391934

Van de Ven, A. H., Hudson, R., \& Schroeder, D. M. (1984). Designing New Business Startups: Entrepreneurial, Organizational, and Ecological Considerations. Journal of Management, 10(1), 87-107.

Van Der Zwan, P., Verheul, I., Thurik, R., \& \& Grilo, I. (2013). Entrepreneurial Progress: Climbing The Entrepreneurial Ladder. Regional Studies, 47(5), 803-825.

https://doi.org/10.1080/00343404.2011.598504 
Vuong, Q. H. (2016). Determinants of firm performance in a less innovative transition system: exploring Vietnamese longitudinal data. Int. J. Transitions and Innovation Systems, 5(1), 2045.

Vuong, Q. H., Bui, Q. K., La, V. P., Vuong, T. T., Nguyen, V. H., Ho, M. T., ... Ho, M. T. (2018). Cultural additivity: behavioural insights from the interaction of Confucianism, Buddhism and Taoism in folktales. Palgrave Communications, 4(1), 1-15. https://doi.org/10.1057/s41599018-0189-2

Vuong, Q. H., \& Napier, N. (2014). Resource curse or destructive creation in transition: Evidence from Vietnam 's corporate sector. Management Research Review, 37(7), 642-657. https://doi.org/10.1108/MRR-12-2012-0265

Walton, A. P. (2003). The impact of interpersonal factors on creativity. International Journal of Entrepreneurial Behaviour \& Research, 9(4), 146-162. https://doi.org/10.1108/13552550310485120

Wauters, B., \& Lambrecht, J. (2008). Barriers to Refugee Entrepreneurship in Belgium : Towards an Explanatory Model Barriers to Refugee Entrepreneurship in Belgium : Towards an Explanatory Model. Journal of Ethnic and Migration Studies, 34(6), 895-915. https://doi.org/10.1080/13691830802211190

Welter, F., \& Smallbone, D. (2011). Institutional Perspectives on Entrepreneurial Behavior in Challenging Environments. Journal of Small Business Management, 49(1), 107-125.

Wilson, K. (2008). Entrepreneurship Education in Europe. Entrepreneurship and Higher Education, $1-20$.

Yen, H. T. H. (2017). Develop a criteria system to evaluate policies to promote entrepreneurship in the globalization. Journal of Science Hanoi National University, 3, 72-93.

Yen, T. T. B., Minh, L. B., \& Huong, T. T. (2019). Analyzing the barriers to innovation development in emerging economies : Vietnamese small and medium enterprises (smes) as an empirical case. Asian Economic and Financial Review, 9(1), 64-77. https://doi.org/10.18488/journal.aefr.2019.91.64.77

Zhang, Y., \& Yang, J. (2006). New venture creation : evidence from an investigation into Chinese entrepreneurship. Journal of Small Business and Enterprise Development, 13(2), 161-173. https://doi.org/10.1108/14626000610665872

Zhao, H., \& Seibert, S. E. (2006). The Big Five Personality Dimensions and Entrepreneurial Status : 
A Meta-Analytical Review. Journal of Applied Psychology, 91(2), 259-271.

https://doi.org/10.1037/0021-9010.91.2.259

Zhao, H., Seibert, S. E., \& Hills, G. E. (2005). The Mediating Role of Self-Efficacy in the Development of Entrepreneurial Intentions. Journal of Applied Psychology, 90(6), 1265-1272. https://doi.org/10.1037/0021-9010.90.6.1265 